GABRIEL ROZEMBERG NIZZO 

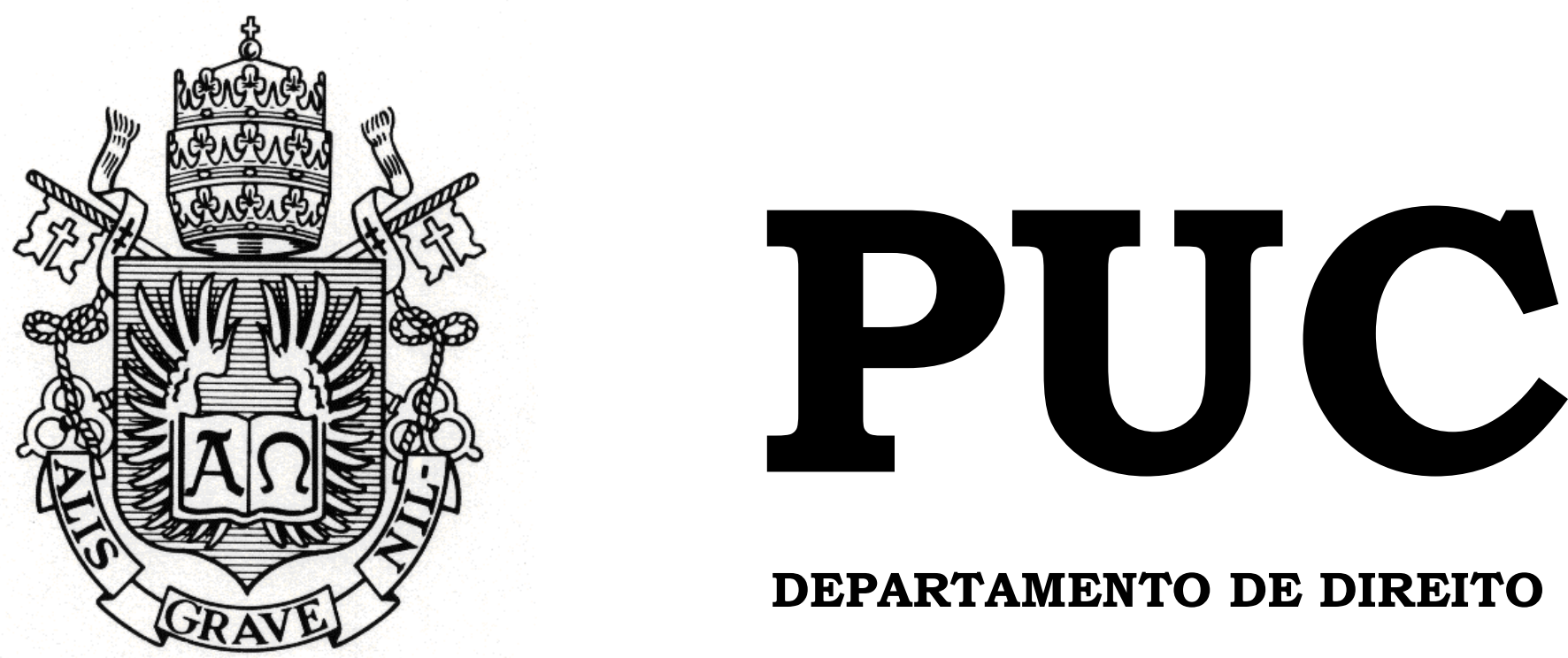

DEPARTAMENTO DE DIREITO

Organização criminosa: Uma análise crítica da legislação nacional vigente e seus obstáculos frente ao princípio da legalidade

por

Gabriel Rozemberg Nizzo

ORIENTADOR(A): PROF.VICTORIA-AMÁlIA DE B. C. G. DE SULOCKI

2010.1

PONTIFÍCIA UNIVERSIDADE CATÓLICA DO RIO DE JANEIRO

RUA MARQUÊS DE SÃO VICENTE, 225 - CEP 22453-900

RIO DE JANEIRO - BRASIL 


\title{
Organização criminosa: Uma análise critica da legislação nacional vigente e seus obstáculos frente ao principio da legalidade
}

\author{
por \\ Gabriel Rozemberg Nizzo
}

Monografia apresentada ao Departamento de Direito da Pontifícia Universidade Católica do Rio de Janeiro (PUC-Rio) como requisito parcial para a obtenção do Título de Bacharel em Direito.

Orientador(a): PROF.VICTORIAAMÁlIA DE B. C. G. DE SULOCKI 


\section{Agradecimento}

Agradeço a todos os mestres que, até o memento, tive em minha vida. Tenham sido eles professores, familiares ou amigos.

Os primeiros me deram o conhecimento técnico, contribuindo significativamente para a formação do meu futuro profissional, assim como para escrever sobre este assunto, fornecendo as ferramentas e o suporte que necessitava.

Já meus familiares e amigos contribuíram significativamente na minha formação pessoal. São responsáveis por importantes colaborações na construção de quem eu sou e de meus ideais.

Ciente de tal fato, lhes sou eternamente grato.

Finalmente, tenho a convicção de que, muitas das vezes, as maiores e melhores lições são aquelas que nos são passadas em uma conversa informal, sem maiores pretensões e, assim, agradeço a todos que tiveram a paciência, de comigo, debaterem sobre os mais variados assuntos. 


\section{Resumo}

O presente trabalho tem como escopo analisar os perigos que advêm da utilização do termo "organização criminosa", principalmente por parte do Judiciário, sem uma prévia definição legal.

A indefinição conceitual do termo, ainda que amplamente presente na legislação vigente, deixando-o a cargo da doutrina e da jurisprudência mostra-se altamente danosa a diversos direitos do cidadão, a título de exemplo, considerando ser o acusado de tráfico de drogas, nos termos do artigo 33 da Lei 11.343/06, integrante de organização criminosa, ainda que todos os demais elementos lhe sejam favoráveis, não poderá valer-se da redução que trata o $\S 4^{\circ}$ do referido artigo, no entanto, a definição do que seja "organização criminosa" recairá sobre o juiz, mostrando-se puramente subjetiva e, em não raros casos, funcionando como a brecha necessária para o abuso de poder. ${ }^{1}$

Sua presença em diversos diplomas legais, sempre reduzindo direitos e garantias do acusado ou do condenado, demanda uma definição hermética que somente a lei é capaz de dar, deixar ao alvedrio dos juristas e magistrados, influenciados pelo discurso midiático que prega o Direito Penal do Inimigo, é flagrante violação do princípio da legalidade e um mandato social para o cometimento de injustiças causadas pelo abuso de poder.

Palavras Chaves: Organização criminosa; Direito penal de emergência; Discurso midiático; Direito penal do inimigo; Princípio da Legalidade e da ofensividade.

\footnotetext{
${ }^{1}$ Art. 33. (...)

Pena - reclusão de 5 (cinco) a 15 (quinze) anos e pagamento de 500 (quinhentos) a 1.500 (mil e quinhentos) dias-multa. (...)

$4^{4^{\circ}}$ Nos delitos definidos no caput e no $\S 1^{\circ}$ deste artigo, as penas poderão ser reduzidas de um sexto a dois terços, vedada a conversão em penas restritivas de direitos, desde que o agente seja primário, de bons antecedentes, não se dedique às atividades criminosas nem integre organização criminosa.
} 


\section{Sumário}

Agradecimento 2

Resumo 3

Lista de Abreviações 5

Capítulo 1 - A realidade social e a influencia do discurso midiático no Direito Penal.

1.1 - Sobre a utilidade de se eleger um mal; 6

1.2 - Panorama da sociedade brasileira atual; 8

Capítulo 2 - O que se entende por Organização Criminosa?

2.1 - A confusão legislativa 18

2.2 - O princípio da Legalidade e sua função de restrição dos atos Estatais; 35

2.3 - A questão do princípio da legalidade na Lei. 9.034/1995, com as modificações feitas pela Lei. 10.217/2001; 37

2.4 - Da impossibilidade de se recorrer à Convenção das Nações Unidas Contra o Crime Organizado Transnacional; 48

\section{Capítulo 3 - Críticas ao Projeto de lei 150/06}

3.1- Do PLS 150/2006; 51

3.2 - O problema da dupla inconstitucionalidade do tipo penal de organização criminosa que se pretende criar; 58

Capítulo 4 - Conclusão 66

Bibliografia 71

Anexo A - Decreto 5.015/2004 75 


\section{Lista de abreviações}

CF - Constituição Federal

CP - Código Penal

CPP - Código de Processo Penal

PL - Projeto de Lei

PLC - Projeto de Lei da Câmara

PLS - Projeto de Lei do Senado

RDD - Regime Disciplinar Diferenciado

STF - Supremo Tribunal Federal

TRF - Tribunal Regional Federal 


\section{Capitulo 1}

\section{A realidade social e a influencia do discurso midiático no Direito Penal}

\section{1 - Sobre a utilidade de se eleger um mal}

A afirmação de que o homem é um animal social já não mais demanda qualquer discussão. De fato, necessitamos para sobreviver, de nos organizarmos em sociedade. Desta necessidade, primeiro surgiram os clãs ou tribos, cujos integrantes eram pertencentes de uma mesma linhagem sanguínea e que tinham como líder o patriarca, nas tribos patriarcais, ou uma matriarca, nas matriarcais. A história demonstra que não raras eram as rixas entre clãs vizinhos, algumas perduravam por toda a sua existência.

Dentro desta realidade, quem detém o poder e o status social é o guerreiro que se destaca em batalha. A guerra é normal, sendo a paz o estado de exceção, portanto, pode-se chefiar com um rigor maior, pois se vive dentro da cultura da força.

Em um processo contínuo, essas aglomerações cresceram e a forma de controle mudou. Surgem as cidades e os governos, mas as disputas permanecem inalteradas. Na Roma Antiga, uma sociedade imperialista, o inimigo deixa de ser uma cidade rival, pois esta poderia ser conquistada, mas sim aqueles agrupamentos que se encontravam a margem do Império Romano, sendo por eles denominados de bárbaros, pelo simples fato de não estarem sob o julgo do Império.

Havia em Roma uma dicotomia, o Direito era aplicado aos cidadãos romanos, limitando a atuação do Estado, vez que havia direitos e garantias a serem respeitados, no entanto, quanto àqueles que não se encontravam sob o domínio do Império, o Estado podia agir ilimitadamente. Entretanto, o medo 
de uma invasão bárbara permitia que o governante limitasse alguns direitos dos pré-estabelecidos.

Começamos a perceber uma constante, a sociedade, desde os seus primórdios, necessita de um inimigo. Os governos, para legitimarem certos atos e manterem o controle social, necessitam eleger um mal e difundir o medo entre seus súditos. Com a chegada da Idade Média, a formação dos Estados Nacionais e a sedimentação do poderio da Igreja Católica sobre estes, tal fato fica cristalino, surgem a caça às bruxas, as Cruzadas, o combate aos hereges.

Nos Estados Modernos, novos inimigos são eleitos. O comunismo, selecionado como o grande mal após a Revolução Soviética, gerou pânico entre as sociedades capitalistas ocasionando o surgimento de governos ditatoriais que se instauraram e legitimaram seus atos de violência com base no discurso de defesa do território contra o avanço do socialismo, não sendo o Brasil exceção.

Entretanto, não só nos Governos Ditatoriais a eleição de um mal e a propagação do medo funciona para legitimar atos restritivos de direitos ou de violação da dignidade da pessoa humana. Contemporaneamente, em Estados Democráticos de Direito, como os Estados Unidos da América, após os ataques terroristas sofridos, o discurso do medo mostra-se forte o suficiente para que uma sociedade abdique de direitos fundamentais em nome de uma maior ingerência do Governo na vida privada de seus cidadãos. Com a promulgação do USA Patriot $A c t^{2}$, verifica-se o fortalecimento do Estado com a supressão de direitos e institutos que serviam de freio a atos abusivos do governo, exterminando, por conseguinte, inúmeras garantias individuais.

\footnotetext{
${ }^{2}$ Public Law 107-56 do Congresso Nacional Americano, de 26 de outubro de 2001, que embora seja mundialmente conhecida por sua abreviação, tem o nome de "UNITING AND STRENGTHENING AMERICA BY PROVIDING APPROPRIATE TOOLS REQUIRED TO INTERCEPT AND OBSTRUCT TERRORISM (USA PATRIOT ACT) ACT OF 2001" Disponível em <http://www.fincen.gov/statutes_regs/patriot/index.html〉. Acesso em 02 jun. 2010.
} 
A mídia noticiava constantemente sobre o chamado "eixo do mal", servindo para a propagação do medo entre os cidadãos americanos, principalmente, mas atingindo boa parte do mudo ocidental.

$\mathrm{Na}$ Itália, há anos foi realizado um recrudescimento das leis penais e processuais com o intuito de se combater a Máfia.

Pelo exposto, sejam tribos vizinhas, cidades, bárbaros, bruxas, hereges, comunistas, organizações criminosas ou terroristas, o que se verifica é que o período histórico muda, as sociedades mudam, o inimigo muda, mas a sua necessidade e utilidade jamais desaparece.

\section{2 - Panorama da sociedade brasileira atual}

A sociedade brasileira vive sob um torpor causado pela sensação de insegurança amplamente propagada e instigada pela mídia, que viu no crime um produto a ser vendido. Somos continuamente bombardeados pelos veículos de comunicação com noticias de crimes que "chocam a nação", utilizando-se de discursos fortes e emotivos.

A cada crime noticiado, demandamos do poder público uma resposta rápida e enérgica, respondemos com o nosso emocional, buscamos vingança contra aqueles que foram vítimas e acreditamos, quase que através de uma sugestão hipnótica, pois nos olvidamos de analisar criticamente a questão, que o problema encontra-se sempre no Direito Penal, mais especificamente, no recrudescimento das leis penais, ditas brandas contra a criminalidade crescente.

"O novo credo criminológico da mídia tem seu núcleo irradiador na própria idéia de pena: antes de mais nada, creem na pena como rito sagrado de solução de conflitos. Pouco importa o fundamento legitimante (...) ${ }^{\text {,3 }}$

Neste sentido, a afirmação do advogado, mestre e doutor em Direito Penal pela USP, Leonardo Sica, que se transcreve a seguir, corrobora as afirmações constantes nos parágrafos anteriores:

\footnotetext{
${ }^{3}$ BATISTA, Nilo. Mídia e Sistema Penal no Capitalismo Tardio. p. 03. Disponível em <www.bocc.ubi.pt/.../batista-nilo-midia-sistema-penal.pdf>. Acesso em 12 mai. 2010.
} 
"O crescimento da violência e a incompetência do Estado para enfrentar o problema, somadas ao agravamento de diversas e variadas tensões sociais, ao clima de pânico irrefletido e fobia coletiva, fomentados, em grande parte, pela mídia, resultam, invariavelmente, na busca frenética e irresponsável por panacéias, por remédios milagrosos e simplistas, capazes de devolver-nos à mítica paz de nossos antepassados e abolir, de vez, toda a insegurança que nos rodeia (sem considerar que a insegurança é um traço da sociedade pósindustrial, ou de risco, que deriva de outros fatores, que não a ausência de repressão estatal).

A demanda por soluções rápidas acaba servindo bem (ou mal?) aos agentes públicos, que, pressionados pelo agravamento da situação e pelo imediatismo da 'opinião publicada', cedem ao mecanismo fácil da edição de medidas de emergência. De fato, nada mais simples, rápido e menos custoso, do que alterar uma lei ou criar uma nova. Essa atividade substitui qualquer necessidade de pesquisa e discussão das causas da criminalidade, das inúmeras faces do fenômeno criminal e, enfim, da elaboração de políticas públicas de prevenção, adequadas à realidade de cada região e de cada manifestação diferente da 'criminalidade'. A regra básica destas demandas de emergência é a crença cega na repressão punitiva, na severidade máxima e nos 'rigores da lei', o que acaba por alimentar a ilusão de que respostas repressivas e violentas são o único e eficaz meio de reduzir a violência (uma contradição lógica) e abater a sensação geral de insegurança. ${ }^{4,}$

Sob idêntica orientação, afirma o renomado jurista Luiz Flávio

\section{Gomes:}

"O uso desvirtuado do Direito penal vem se acentuando a cada ano: 2009 não será (certamente) diferente. Com o aumento da violência, pode explodir o 'populismo penal' do legislador. Tudo depende do comportamento da mídia, que retrata a violência como um 'produto' de mercado. A criminalidade (e a persecução penal), assim, não somente possui valor para uso político (e, especialmente, para uso 'do' político), senão que é também objeto de autênticos melodramas cotidianos que são comercializados com textos e ilustrações nos meios de comunicação. São mercadorias da indústria cultural, gerando, para se falar de efeitos já notados, a banalização da violência (e o consequente anestesiamento da população, que já não se estarrece com mais nada). ${ }^{5,}$

Concluindo sobre o tema, trazemos o exímio ensinamento de René

Ariel Dotti, ao contribuir com importante texto de prefácio no livro

“Organização Criminosa: Nova perspectiva do tipo legal”, de Antonio

Sérgio Altieri de Moraes Pitombo:

"A partir dos anos 90 o legislador criminal brasileiro assumiu o papel de construtor da anarquia do sistema legal, uma espécie de exterminador do futuro, ao sacrificar princípios e garantias constitucionais e legais que pouco a pouco foram atropelados pelo trator da legislação de pânico. Para esse quadro de

\footnotetext{
${ }^{4}$ SICA, Leonardo. Medidas de emergência, violência e crime organizado. Disponível em <http://www.ibccrim.org.br/site/boletim/exibir_artigos.php?id=150>. Acesso em 26 ago. 2009.

${ }_{5}^{5}$ GOMES, Luiz Flávio. Mídia e Direito Penal. Em 2009, o populismo penal pode explodir. Disponível em <http://jus2.uol.com.br/doutrina/texto.asp?id=12274>. Acesso em 12 mai. 2010.
} 
comoção provocada por algumas modalidades de crimes graves, contribuíram decisivamente os meios de comunicação com o discurso sensacionalista. ",

Claríssimas são as lições da professora Ana Lúcia Menezes Vieira sobre este discurso midiático.

"A valorização da violência, o interesse pelo crime e pela justiça penal é uma prática enraizada na mídia, que encontra seu melhor representante no jornalismo sensacionalista. Utilizando-se de um modo próprio de linguagem discursiva, ágil, coloquial e do impacto da imagem, promove uma banalização e espetacularização da violência. O jornalismo informativo, que tem como principal característica buscar o fato despido de valorações, adjetivações ou da opinião pessoal do jornalista, cede espaço à mensagem dramática, narrada descompromissadamente, num discurso fragmentado "engendrado numa fala emotiva, envolvente, morna e difusa, onde o cotidiano dos marginais é posto como uma ficção sedutora ${ }^{7}$,

De forma consciente, não percebemos que buscamos acabar com a violência através de atos de violência, o discurso do medo encontra-se de forma tão entranhada no seio de nossa sociedade que nos esquecemos dos horrores do período ditatorial de outrora e clamamos pelo fim de direitos e garantias fundamentais conquistadas mediante um árduo e tormentoso processo, não raro são os depoimentos de pessoas que vivenciaram tal período e, não obstante, declaram sentir saudades das medidas duras empregadas pelos militares, concluindo que naquele tempo a criminalidade não teria o espaço que tem hoje.

Deixamos-nos influenciar pelo discurso midiático que clama por medidas de emergência sem ter conhecimento sobre as suas consequências futuras, que trazem "especialistas" para falar ao público, nunca sem antes perquirir se seus dizeres se coadunam com a mensagem dura e imediatista que desejam noticiar, que influenciam não só a população em geral e ao políticos oportunistas, mas também aos magistrados que têm a importante missão de decidir de forma imparcial.

Nas palavras do ex-governador do Estado do Rio de Janeiro e respeitável jurista, Nilo Batista:

\footnotetext{
${ }^{6}$ DOTTI, René Ariel. Prefácio. In. PITOMBO, Antonio Sergio Altieri de Moraes. Organizações criminosas: nova perspectiva do tipo legal. São Paulo: Revista dos Tribunais, 2009. p. 17.

${ }^{7}$ VIEIRA, Ana Lúcia Menezes. Processo penal e mídia. São Paulo: Revista dos Tribunais, 2003. p. 55.
} 
"Neste sentido, toda e qualquer reflexão que deslegitime aquele credo criminológico da mídia deve ser ignorada ou escondida: nenhuma teoria e nenhuma pesquisa questionadora do dogma penal, da criminalização provedora ou do próprio sistema penal são veiculados em igualdade de condições com suas congêneres legitimantes. Os editoriais, que desconhecem as primeiras e enaltecem as segundas, estariam, dessa forma, pretendendo escusar-se por uma espécie de erro que lembra a ignorantia affectata do direito canônico. O fato é que a universidade não consegue influenciar o discurso criminológico da mídia, mas a recíproca não é verdadeira: a mídia pauta um bom número de pesquisas acadêmicas, remuneradas em seu desfecho por consagradora divulgação, que revela as múltiplas coincidências que as viabilizaram.",

E continua, abordando a questão dos especialistas no discurso midiático:

"Enunciados secundários do discurso criminológico da mídia ('a impunidade aumenta o número de crimes'; 'nas drogas é como uma escada, passa-se das mais leves para as mais pesadas'; 'penas elevadas dissuadem', etc), que não alcançariam jamais constatação empírica, por serem completamente indemonstráveis, precisam de um respaldo 'cientifico', que os conduza respeitavelmente à doutrina dos editoriais. É aí que entram os especialistas. Como o discurso criminológico da mídia não representa o produto de um esforço na direção do saber, mas sim uma articulação retórico-demonstrativa daquele credo a que nos referimos, ele selecionará os especialistas segundo suas opiniões coincidam ou dissintam daquelas crenças. ${ }^{, 9}$

A força que a mídia tem sobre o Direito penal, influenciando legisladores a editarem leis, magistrados em suas decisões, conduta que foi denominada pelo Ministro Gilmar Mendes de "covardia institucional"10, pois magistrados que levam a sério a tarefa de velar pelas garantias constitucionais e de conter o poder punitivo ilegal ou irracional são, dentro deste discurso, fracos e tolerantes ${ }^{11}$, é inegável. Tal fato levou ao eminente jurista argentino Eugênio Zaffaroni "a incluir, em seu rol de agências do sistema penal, as "agências de comunicação social", e os exemplos que ministrou ("rádio, televisão e jornais") deixam claro que não se referia aos serviços de relações públicas de tribunais ou corporações policiais. " 12

\footnotetext{
${ }^{8}$ BATISTA, Nilo. Mídia e Sistema Penal no Capitalismo Tardio. p. 06. Disponível em <www.bocc.ubi.pt/.../batista-nilo-midia-sistema-penal.pdf〉. Acesso em 12 mai. 2010.

${ }^{9}$ Ibid. p. 08.

${ }^{10}$ STF, HC 86.395-7/SP. Segunda Turma. Relator Ministro Gilmar Mendes. Brasília, 06 nov. 2006.

${ }^{11}$ BATISTA, Nilo. Op. cit., p.10.

${ }^{12}$ Ibid. p. 01.
} 
É inegável que o judiciário é frontalmente atingido quando um magistrado denega ordem de Habeas Corpus, que busca desconstruir a sentença que decretou a prisão provisória tendo como fundamentação o clamor público, em flagrante dissonância com o que preleciona o Código de Processo Penal e a jurisprudência majoritária do Supremo Tribunal Federal, mas em conformidade com a opinião pública. A população leiga e a mídia, neste momento, sedenta por vingança e querendo a punição do acusado, enxerga justiça, os juristas, por outro lado, deveriam ver a injustiça e a rachadura por onde pode fazer ruir todo o nosso sistema penal.

A população, tão influenciada pela mídia e por sua oratória sobre a necessidade de adoção de medidas de emergência, clama por leis duras, penas altas e desproporcionais, restrições das garantias processuais, execução penal rígida e de caráter exclusivamente punitivo, "роисo importando que a criminalização provedora seja uma falácia, uma inócua resposta simbólica, com efeitos reais, atirada a um problema real, com efeitos simbólicos. "13

Infiltrando-se pelos meios de comunicação, nosso sistema de garantias encontra-se ameaçado pela invasão do Direito Penal do Inimigo ${ }^{14}$, ressurgido com Günter Jakobs:

"Bandeiras do Direito Penal de inimigo: o Direito Penal do inimigo, como se vê, (a) necessita da eleição de um inimigo e (b) caracteriza-se ademais pela oposição que faz ao Direito Penal do cidadão (onde vigoram todos os princípios limitadores do poder punitivo estatal). Suas principais bandeiras são: (a) flexibilização do princípio da legalidade (descrição vaga dos crimes e das penas); (b) inobservância de princípios básicos como o da ofensividade, da

\footnotetext{
${ }^{13}$ BATISTA, Nilo. Mídia e Sistema Penal no Capitalismo Tardio. p. 05. Disponível em <www.bocc.ubi.pt/.../batista-nilo-midia-sistema-penal.pdf>. Acesso em 12 mai. 2010.

${ }^{14}$ Sobre o tema, Zaffaroni afirma que Günther Jakobs formulou o que ele chamou de "direito penal do inimigo" como uma proposta tática de contenção do direito penal, causando um debate acirrado no direito penal. Ele ainda explica que Jakobs, até final dos anos 90 criticava o endurecimento penal, mas passou a defendê-lo para alguns (os inimigos em contrapartida ao cidadão) como forma de deter esse endurecimento para todos.

Em suas palavras: "Jakobs utilizou pela primeira vez a expressão para criticar o endurecimento legislativo das últimas décadas, mas, à partir de 1999, diante do ameaçador avanço dessa tendência, passou a defender a mencionada necessidade de sua legitimação parcial como modo de deter o crescimento do próprio "direito penal do inimigo'. Esta mudança de fachada foi uma das causas da singular acidez do debate em torno do tema". (ZAFFARONI, E. Raúl. O Inimigo no Direito Penal. Rio de Janeiro: Revan e Instituto Carioca de Criminologia, 2007, p. 157.)
} 
exteriorização do fato, da imputação objetiva etc.; (c) aumento desproporcional de penas; (d) criação artificial de novos delitos (delitos sem bens jurídicos definidos); (e) endurecimento sem causa da execução penal; $(f)$ exagerada antecipação da tutela penal; $(g)$ corte de direitos e garantias processuais fundamentais; (h) concessão de prêmios ao inimigo que se mostra fiel ao Direito (delação premiada, colaboração premiada etc.); (i) flexibilização da prisão em flagrante (ação controlada); (j) infiltração de agentes policiais; (l) uso e abuso de medidas preventivas ou cautelares (interceptação telefônica sem justa causa, quebra de sigilos não fundamentados ou contra a lei); (m) medi das penais dirigidas contra quem exerce atividade lícita (bancos, advogados, joalheiros, leiloeiros etc. $)^{15}$.

Nota-se cristalina a subsunção da fala da mídia com as diretrizes da doutrina de Jakobs, esquematizadas acima pelo jurista Luiz Flávio Gomes, ademais, verifica-se que estas diretrizes não se encontram apenas na oratória da mídia, mas em leis promulgadas mediante extremo lobby dos veículos de comunicação, tais como a lei de combate ao crime organizado, a lei de crimes hediondos e a lei de drogas, dentre tantas outras.

Mas como legitimar a edição de leis tão duras que somente poderiam ser consideradas inconstitucionais frente ao principio da proporcionalidade, como efetivar este discurso imediatista e de emergência tão impregnado pela Teoria do Direito Penal do Inimigo?

A resposta, no entanto, é simples, faz-se o que a sociedade sempre fez ao longo da história, isto é, elege-se um inimigo a ser combatido, dissemina-se o medo entre os cidadãos e faz com que se acredite que sem tais medidas a sociedade em que vivemos sucumbirá. Nas palavras de Leonardo Sica, "criam-se demônios e buscam-se panaceias", 16

Com isto, eleva-se a criminalidade a outro patamar, o crime cometido por um criminoso insignificante não enseja o estabelecimento de um inimigo, até porque o crime deriva da própria natureza humana, logo, onde há sociedade há crime, mas a atuação de uma "organização criminosa", esta sim enseja a materialização do inimigo.

\footnotetext{
${ }^{15}$ GOMES, Luiz Flávio. Direito penal do inimigo (ou inimigos do Direito penal). Disponível em $\langle\mathrm{http} / / /$ www.revistajuridicaunicoc.com.br/midia/arquivos/ArquivoID_47.pdf $\rangle$. Acesso em 12 mai. 2010.

${ }^{16}$ SICA, Leonardo. Medidas de emergência, violência e crime organizado. Disponível em <http://www.ibccrim.org.br/site/boletim/exibir_artigos.php?id=150>. Acesso em 26 ago. 2009.
} 
O mestre René Ariel Dotti, analisando o tema, chega à mesma conclusão, corroborando as afirmações supra.

"A frustração dos disegno di legge para uma fórmula racional sintética que possa delimitar os contornos típicos da organização criminosa é bem exposta diante da conclusão de que as leis que acolhem parâmetros conhecidos de 'aumentar as penas, ampliar o arsenal investigatório, de reduzir os direitos e garantias do processo penal e recrudescer a execução da pena privativa de liberdade', são diplomas que encaram os acusados como inimigos 'e que se voltam a refletir perseguição a pessoa, ou grupo de pessoas, e não a condutas concretas'. Neste trecho a investigação lembra a evolução legislativa dos últimos tempos, caracterizadoras de um direito penal de ocasião fomentado por uma política criminal de emergência." "17 (grifei)

Verifica-se que houve uma mitificação do crime, este agora passou a ser cometido, em sua grande maioria, pelas organizações criminosas ou a mando delas. O criminoso comum, principalmente o traficante de drogas, foi promovido à integrante de tais organizações com fins delituosos. A mídia grita em alto e bom som sobre a guerra conta o crime organizado e clama por medidas efetivas para o seu combate, utilizando-se, como se percebe, termos bélicos para enfatizar e aumentar a sensação de insegurança.

Buscando novamente os ensinamentos de autoridade de René Ariel Dotti, temos:

"Essa entidade (organização criminosa) abstrata e concreta, mítica e real aparece em vários dispositivos do ordenamento penal brasileiro (...),"18

Atingimos, portanto, a esquizofrenia de combatermos um inimigo imaginário, atuando como Dom Quixote de La Mancha contra moinhos, infelizmente, sem a sua poesia, pois não há no nosso ordenamento jurídico, a despeito da lei 9.034/95 e de sua menção em diversos outros diplomas legais, como devidamente mencionado pelo ilustre René Ariel Dotti, a definição do que seja uma organização criminosa.

"No caso da 'guerra contra o crime organizado', palavra de ordem uníssona em todos os escalões da vida nacional, de alto a baixo, da esquerda à direita, essa

\footnotetext{
${ }^{17}$ DOTTI, René Ariel. Prefácio. In. PITOMBO, Antonio Sergio Altieri de Moraes. Organizações criminosas: nova perspectiva do tipo legal. São Paulo: Revista dos Tribunais, 2009. p. 10.

${ }^{18}$ Ibid. p. 14.
} 
figura chega a beirar o ridículo num país em que sequer ainda obteve-se uma definição jurídica precisa de crime organizado",19.

Neste mesmo sentido, são os ensinamentos de Fernando Capez:

"Embora se saiba, no entanto, o que significa quadrilha ou bando (basta conferir a redação do art. 288 do CP), bem como associação criminosa (art. 35 da Lei $n^{\circ} 11.343 / 2006$, ainda não se tem a menor ideia do que venha a ser organização criminosa. É claro que ela pode ser definida doutrinariamente, porem isso ofenderia o principio da reserva legal. Assim, a Lei do Crime Organizado somente pode ser aplicada aos crimes de quadrilha ou bando e de associação criminosa. Às chamadas organizações criminosas ainda não, pois não se sabe o que significam. Por essa razão, todos os dispositivos da lei que se referem à organização criminosa são inaplicáveis, dado que são institutos atinentes a algo que ainda não existe ${ }^{20, "}$ (grifei)

De forma poética, no entanto proferindo os mesmos ensinamentos, diz Luiz Flávio Gomes que "organização criminosa, portanto, hoje, no ordenamento jurídico brasileiro, é uma alma (uma enunciação abstrata) em busca de um corpo (de um conteúdo normativo, que atenda o princípio da legalidade)."21

Demonstrando que o Brasil teve duas oportunidades de conceituar organização criminosa, na edição da lei 9.034/95 e posteriormente com a edição da lei 10.217/01, Rafael Pacheco afirma:

"Como se vê, o Brasil possui duas leis que cuidam do crime organizado e ainda não se sabe juridicamente o que é isso, pois os legisladores brasileiros, diferentemente de seus pares em outras nações, optaram por não definir seus respectivos alcances, não instituir qualquer parâmetro limitador das expressões contidas no novo texto, tampouco as ações delituosas que pudessem ser objeto dessas leis ${ }^{, 22}$

Conforme se demonstrará nos capítulos seguintes, esta opção por omitir-se em dar a definição legal de organização criminosa acarretou em tornar letra morta todos os dispositivos que fazem menção a esta estrutura criminosa, vez que flagrante é a violação do princípio da reserva legal.

\footnotetext{
19 SICA, Leonardo. Medidas de emergência, violência e crime organizado. Disponível em $<$ http://www.ibccrim.org.br/site/boletim/exibir_artigos.php?id=150>. Acesso em 26 ago. 2009.

${ }^{20}$ CAPEZ, Fernando. Curso de Direito Penal: Legislação Penal Especial. vol. 4. $4^{a}$ ed. São Paulo: Saraiva, 2009. p. 245.

${ }^{21}$ GOMES, Luiz Flávio. Que se entende por crime organizado. Disponível em <http://jus2.uol.com.br/doutrina/texto.asp?id=12274>. Acesso em 12 mai. 2010.

${ }^{22}$ PACHECO, Rafael. Crime organizado: medidas de controle e infiltração policial. Coritiba: Joruá, 2008. p. 50.
} 
Não se pode permitir, por conseguinte, que se restrinjam direitos processuais e garantias do acusado ou condenado, pela incidência de normas penais sem conteúdo definido, pois os riscos são inegavelmente altos, além de contrários ao ordenamento jurídico vigente, atingindo as bases do Estado Democrático de Direito.

Tendo-se em mente que foi a mídia quem disseminou o mito, não se estaria exagerando ao falar que é ela quem detém maior poder para definir ou, ao menos, influenciar aqueles que se vêm frente à tarefa de defini-la. Para tanto, basta analisar a forma como é transmitida a noticia de uma investigação policial, rotulando, acima de qualquer dúvida, o acusado como membro de organização criminosa, ainda na fase pré-processual, diante apenas de indícios de uma cumulação subjetiva.

Consultando-se o site do jornal O Globo é possível ter ideia da quantidade inimaginável de reportagens que trazem como tema central as organizações criminosas. Nota-se, contudo, uma desordem de termos postos como sinônimos, mas juridicamente distintos, sem qualquer cuidado de quem pretende escrever seriamente sobre o tema, verifica-se, cabalmente, que a escolha do termo fica ao alvedrio do jornalista.

A reportagem mais recente traz como manchete o seguinte: Polícia desarticula na Paraíba quadrilha que comprava droga na Bolívia e vendia em 3 estados do Nordeste ${ }^{23}$, sendo que já no segundo parágrafo da noticia o termo utilizado é substituído por organização criminosa, apoiando-se na suposta fala do secretário estadual de Segurança Pública e Defesa Social do Estado da Paraíba, Gustavo Gominho.

Cristalina, portanto, os riscos da subjetividade que se encontra o conceito de organização criminosa, pois qualquer um pode sentir-se no

\footnotetext{
${ }^{23}$ PORTAL Paraíba 1. Polícia desarticula na Paraíba quadrilha que comprava droga na Bolívia e vendia em 3 estados do Nordeste. Publicada em 13/05/2010 às 15:10. Disponível em <http://oglobo.globo.com/cidades/mat/2010/05/13/policia-desarticula-na-paraiba-quadrilha-quecomprava-droga-na-bolivia-vendia-em-3-estados-do-nordeste-916573734.asp>. Acesso em 13 mai. 2010.
} 
direito de defini-la, ainda que não disponha de conhecimento técnico para tanto.

Constatando a questão da subjetividade, transcrevemos os escritos de Rafael Pacheco:

"A necessidade de se definir com urgência o que é uma organização criminosa é atender ao principio da legalidade que constitui, por si só, o fundamento do Direito Penal em um Estado Democrático de Direito.

Claro está que, no ordenamento jurídico pátrio, a expressão 'organização criminosa' ainda se encontra no campo da avaliação subjetiva, quanto às suas significações efetivamente possíveis em um conceito fluído e impreciso." 24

Discordamos do referido autor ao concluir que "Assim sendo, podese afirmar, com base na realidade brasileira, ser trabalho doutrinário e jurisprudencial sua conceituação, uma vez que a legislação pátria é omissa $^{, 25}$, pois, como afirmamos e demonstraremos a seguir, havendo restrição ou supressão de direitos ou garantias, necessária uma definição hermética que somente a lei é capaz de dar, vez que deixar ao alvedrio dos juristas e magistrados, influenciados pelo discurso midiático, é flagrante violação do princípio da legalidade e um mandato social para o cometimento de injustiças causadas pelo abuso de poder.

Em suma, diante dos autos índices de violência e de um discurso midiático clamando por medidas de emergência, buscou-se nas organizações criminosas a figura do mal, mediante difusão do medo. Estabelecido um inimigo a ser combatido, tais medidas de emergência, quase sempre leis imediatistas e de recrudescimento penal, foram editadas e promulgadas com o apoio popular, entretanto, políticos oportunistas que editaram tais leis olvidaram-se de conceituá-la, havendo, deste modo, uma lacuna perigosa, pois, o seu preenchimento por parte da doutrina e da jurisprudência mostra-se puramente subjetivo e, portanto, servindo como brecha para o cometimento de atos de abuso de poder.

\footnotetext{
${ }^{24}$ PACHECO, Rafael. Crime organizado: medidas de controle e infiltração policial. Coritiba: Joruá, 2008. p.51.

${ }^{25} \mathrm{Ibid}$
} 


\section{Capítulo 2}

\section{O que se entende por Organização Criminosa?}

\section{1 - A confusão legislativa}

Conforme exposto no capítulo anterior, o discurso do medo, veiculado pela mídia, influi na sociedade de forma que esta clame por medidas repressivas do Estado, acreditando, com isto, que o índice de criminalidade diminuirá. O Estado, por sua vez, despreparado e, em alguns momentos, acomodado, acaba por aplicar a solução mais fácil, editando e remendando leis, olvidando-se, contudo, de um debate sério acerca do tema.

Busca-se no Direito penal a solução para as mazelas sociais, ignorando a amplitude do problema, esquivando, o Estado, da sua responsabilidade pelo abandono de certos setores sociais, relegando uma parcela significativa da população a sua própria sorte, sem que seus direitos constitucionais à educação, saúde e moradia, dentro dos ditames do princípio da dignidade da pessoa humana, sejam cumpridos.

Mais especificamente, buscam-se no Direito penal de emergência as respostas aos índices de criminalidade crescente, com a inquieta atividade legislativa, editando e promulgando leis no campo penal, sem qualquer cuidado ou respeito à sistematização ou aos princípios constitucionais.

Neste diapasão destacamos o princípio da proporcionalidade, vez que as leis provenientes desta vertente do Direito penal têm como característica a previsão de penas duras para crimes que, quando comparados com outros pré-existentes, mostram-se menos lesivos a bens jurídicos ou o próprio bem jurídico tutelado não é dotado de significativa relevância.

Quando não definem crimes, consistem em leis penais e processuais que visam à restrição de direitos e de garantias, vedando a concessão de 
liberdade provisória, com ou sem fiança ${ }^{26}$, aumentando a duração do processo, endurecendo o regime de cumprimento de pena, impossibilitando a aplicação da redução da pena, mesmo quando preenchidos os demais elementos objetivos e subjetivos, enfim, os exemplos são infinitos.

Corroborando as afirmações supras, são validos os ensinamentos da professora e doutora de Direito Penal da USP, Ana Elisa Liberatore S. Bechara:

\footnotetext{
${ }^{26}$ O STF já se pronunciou a respeito da inconstitucionalidade de leis genéricas que vedam a liberdade provisória, ao julgar a Adi 3112/DF, entendendo que violam o princípio da presunção de inocência e da obrigatoriedade de fundamentação dos mandados de prisão pela autoridade judiciária competente.
}

Ementa

EMENTA: AÇÃO DIRETA DE INCONSTITUCIONALIDADE. LEI 10.826/2003. ESTATUTO DO DESARMAMENTO. INCONSTITUCIONALIDADE FORMAL AFASTADA. INVASÃO DA COMPETÊNCIA RESIDUAL DOS ESTADOS. INOCORRÊNCIA. DIREITO DE PROPRIEDADE. INTROMISSÃO DO ESTADO NA ESFERA PRIVADA DESCARACTERIZADA. PREDOMINÂNCIA DO INTERESSE PÚBLICO RECONHECIDA. OBRIGAÇÃO DE RENOVAÇÃO PERIÓDICA DO REGISTRO DAS ARMAS DE FOGO. DIREITO DE PROPRIEDADE, ATO JURÍDICO PERFEITO E DIREITO ADQUIRIDO ALEGADAMENTE VIOLADOS. ASSERTIVA IMPROCEDENTE. LESÃO AOS PRINCÍPIOS CONSTITUCIONAIS DA PRESUNÇÃO DE INOCÊNCIA E DO DEVIDO PROCESSO LEGAL. AFRONTA TAMBÉM AO PRINCÍPIO DA RAZOABILIDADE. ARGUMENTOS NÃO ACOLHIDOS. FIXAÇÃO DE IDADE MÍNIMA PARA A AQUISIÇÃO DE ARMA DE FOGO. POSSIBILIDADE. REALIZAÇÃO DE REFERENDO. INCOMPETÊNCIA DO CONGRESSO NACIONAL. PREJUDICIALIDADE. AÇÃ̃O JULGADA PARCIALMENTE PROCEDENTE QUANTO À PROIBIÇÃO DO ESTABELECIMENTO DE FIANÇA E LIBERDADE PROVISÓRIA. I - Dispositivos impugnados que constituem mera reprodução de normas constantes da Lei 9.437/1997, de iniciativa do Executivo, revogada pela Lei 10.826/2003, ou são consentâneos com o que nela se dispunha, ou, ainda, consubstanciam preceitos que guardam afinidade lógica, em uma relação de pertinência, com a Lei 9.437/1997 ou com o PL 1.073/1999, ambos encaminhados ao Congresso Nacional pela Presidência da República, razão pela qual não se caracteriza a alegada inconstitucionalidade formal. II - Invasão de competência residual dos Estados para legislar sobre segurança pública inocorrente, pois cabe à União legislar sobre matérias de predominante interesse geral. III - O direito do proprietário à percepção de justa e adequada indenização, reconhecida no diploma legal impugnado, afasta a alegada violação ao art. $5^{\circ}$, XXII, da Constituição Federal, bem como ao ato jurídico perfeito e ao direito adquirido. IV - A proibição de estabelecimento de fiança para os delitos de "porte ilegal de arma de fogo de uso permitido" e de "disparo de arma de fogo", mostra-se desarrazoada, porquanto são crimes de mera conduta, que não se equiparam aos crimes que acarretam lesão ou ameaça de lesão à vida ou à propriedade. V - Insusceptibilidade de liberdade provisória quanto aos delitos elencados nos arts. 16, 17 e 18. Inconstitucionalidade reconhecida, visto que o texto magno não autoriza a prisão ex lege, em face dos princípios da presunção de inocência e da obrigatoriedade de fundamentação dos mandados de prisão pela autoridade judiciária competente. VI - Identificação das armas e munições, de modo a permitir o rastreamento dos respectivos fabricantes e adquirentes, medida que não se mostra irrazoável. VII - A idade mínima para aquisição de arma de fogo pode ser estabelecida por meio de lei ordinária, como se tem admitido em outras hipóteses. VIII - Prejudicado o exame da inconstitucionalidade formal e material do art. 35, tendo em conta a realização de referendo. IX - Ação julgada procedente, em parte, para declarar a inconstitucionalidade dos parágrafos únicos dos artigos $14 \mathrm{e}$ 15 e do artigo 21 da Lei 10.826, de 22 de dezembro de 2003. (grifei) (STF, ADI 3112 / DF. Rel. Min. Ricardo Lewandowski., Brasília, 02 mai. 2007) 
"Essa sensação de (in)segurança, substancialmente aumentada pela imprensa, converte-se em uma pretensão social a que o Estado, por meio do Direito Penal, deve fornecer uma resposta. Assim, frente aos movimentos sociais clássicos de restrição do Direito Penal, aparecem cada vez mais demandas de uma ampliação da proteção penal que ponha fim, ainda que nominalmente, à angústia da insegurança coletiva. E tal aspiração de uma coletividade que se autocompreende antes de tudo como vítima conduz à rejeição de formas e procedimentos. De fato, ao estruturar-se tal demanda social, nem sequer importa que seja preciso modificar as garantias clássicas do Estado Democrático de Direito. Ao contrário, referidas garantias, dentre as quais destacam-se os próprios princípios penais fundamentais e os elementos da teoria geral do delito, relevam-se, no novo contexto, como demasiadamente rígidas, opondo-se, assim, à solução efetiva dos casos concretos ${ }^{27}$,"

Válidas são também as digressões de Cláudio Ribeiro Lopes, em artigo publicado no site do Instituto Brasileiro de Ciências Criminais IBCCRIM - intitulado “O Direito Penal de Emergência, os microssistemas, o discurso pan-penalista e o caráter limitador do princípio penal de legalidade estrita" chama a atenção para a expansão do chamado discurso pan-penalista:

"Veja-se: crê-se, sinceramente, que o direito penal deva ser a ferramenta para educação de um povo? Esta seria uma função legítima para o sistema penal num Estado de direito, democrático e social? Que função é esta que o discurso panpenalista vem propondo?

A idéia motriz é de que o direito penal clássico - o de garantias - estaria ultrapassado, tal qual um velho paquiderme (lento, moroso, incapaz de dar uma resposta rápida à criminalidade crescente ou à nova criminalidade do mundo pós-moderno, globalizado). Assim, Silva Sánchez (3) chega a propor que se estabeleçam três espécies de sistemas penais: o clássico (de primeira velocidade, dotado de todas as garantias conhecidas e que derivam, necessariamente, da herança iluminista), um outro direito ou sistema penal, mais leve, mais ágil, desprovido de parte das garantias para que pudesse ser eficaz e que laborasse com penas restritivas de direitos, basicamente.

De conseguinte, um direito penal de duas velocidades, também chamado de direito administrativo sancionador, traria em si o caráter de flexibilização do princípio de legalidade penal.

Por outro lado, restaria o direito penal de terceira velocidade (ou, direito penal do inimigo), destinado ao combate à criminalidade organizada, ao terrorismo, onde as garantias fundamentais seriam solapadas em nome do sistema penal de eficiência, sob o manto da emergência, aliás, sempre convenientemente presente. $^{28}$ " (grifei)

\footnotetext{
${ }^{27}$ BECHARA, Ana Elisa Liberatore S. "Caso Isabella": violência, mídia e direito penal de emergência. Disponível em <http://www.ibccrim.org.br/site/boletim/exibir_artigos.php?id=3652>. Acesso em 12 mai. 2010.

${ }^{28}$ LOPES, Cláudio. O Direito penal de emergência, os microssistemas, o discurso pan-penalista e $o$ caráter limitador do princípio penal de legalidade estrita. Disponível em <http://www.ibccrim.org.br/site/artigos/capa.php?jur_id=7589>. Acesso em 17 mai. 2010.
} 
Indispensáveis estas linhas introdutórias para se entender o cenário brasileiro ao tempo da edição da Lei 9.034/1995, que dispõe sobre a utilização de meios operacionais para a prevenção e repressão de ações praticadas por organizações criminosas.

Proposta pelo Deputado Federal Michel Temer, em setembro de 1989, com escopo de introduzir meios operacionais para a prevenção e repressão do crime organizado, ainda que a ementa fosse passível de crítica, vez que não tipificava o crime organizado, portanto, impossível seria, diante do principio da legalidade, reprimir uma conduta carente de tipificação legal, destinava-se, na verdade, em oferecer uma maior gama de instrumentos, na fase de inquérito, para se buscar a autoria e materialidade dos crimes provenientes da chamada criminalidade organizada.

Assim é também a conclusão de Antônio Sérgio Altieri de Moraes Pitombo, ao afirmar que "Portanto, o foco de interesse não estava na associação para a prática de crime, mas nas infrações penais perpetradas de forma coletiva ${ }^{29}$."

Pecou, novamente, ao utilizar o termo "crime organizado", quando na verdade não é o crime que se organiza, mas sim os homens, sujeitos ativos, que criam um sistema organizacional com intuito de perpetrarem crimes.

Não obstante os problemas até então apontados, encontrava-se no PL louvável esforço no sentido de conceituar legalmente uma organização criminosa, artigo que foi, em má hora, retirado do projeto final.

O artigo $2^{\circ}$ do PL 3.516/89 tinha a seguinte redação:

“Art. 2. ${ }^{\circ}$ Para efeitos desta Lei, considera-se organização criminosa aquela que, por suas características, demonstre a existência de estrutura criminal, operando de forma sintetizada, com atuação regional, nacional elou internacional.

Parágrafo único. São meios operacionais de prevenção e repressão do crime organizado:

I-A infiltração policial;

\footnotetext{
${ }^{29}$ PITOMBO, Antonio Sergio Altieri de Moraes. Organizações criminosas: nova perspectiva do tipo legal. São Paulo: Revista dos Tribunais, 2009. p. 90.
} 
II - As ações controladas;

III - $O$ acesso a documentos e informações fiscais, bancárias, financeiras e eleitorais;

$I V$ - O impedimento, a interrupção, a interceptação, a escuta e a gravação das comunicações telefônicas, conforme regulado em lei especial."

Louvável a intenção de conceituar organização criminosa, entretanto, podemos dizer que o PL trazia uma "definição indefinida", isto porque não trazia precisão ao utilizar-se de conceitos vazios ("estrutura criminal"), vagos ("forma sintetizada"), assim como não fixando limites, isto é, trazendo, para dentro do que deveria ser uma definição, a subjetividade, ao dizer que organização criminosa é aquela que "por suas características, demonstre a existência de estrutura criminal".

Não se entende, portanto, da leitura deste artigo, o que seja uma organização criminosa. Sendo certo que a doutrina não chega a um acordo sobre qual é a correta definição, existindo diferentes teorias para conceituála, também é verdade que todas elas fazem um esforço para buscar a essência deste conceito. O PL, contudo, descartou todo o esforço doutrinário e, como consequência, careceu destes elementos.

"Percebe-se, desde logo, que definição não havia. Faltou indicar características específicas que mostrassem a particularidade da organização criminosa. Fica clara, assim, a ausência da fixação de limites, bem como o descuido na descrição do que seria a essência do fenômeno associativo. ",30

Ademais, assusta o fato de constarem, no grupo de trabalho que contribuiu para a elaboração do Projeto de Lei 3.516, os nomes de respeitáveis juristas, dentre eles Ada Pellegrini Grinover e Antonio Scarance Fernandes, vez que, manifestamente, o projeto de lei se insere nos moldes das leis do direito penal do inimigo ${ }^{31}$, além de trazer normas de constitucionalidade bastante questionável, tal qual a contida no artigo $4^{\circ}$ do PL, que de forma cristalina viola o princípio da ampla defesa e do contraditório, tão bem explicitados e defendidos pela professora Ada

\footnotetext{
${ }^{30}$ PITOMBO, Antonio Sergio Altieri de Moraes. Organizações criminosas: nova perspectiva do tipo legal. São Paulo: Revista dos Tribunais, 2009. p. 90.

${ }^{31}$ Consultar capítulo 1, item 1.2.
} 
Pellegrini Grinover em suas obras, bem como o da publicidade, ao manter em sigilo as "fontes de informação".

Para tanto, basta uma rápida leitura do PL para se perceber o que se afirma, vejamos:

"Nas disposições gerais, retiravam-se direitos do processo penal mediante: a identificação criminal obrigatória (art. 10 do Projeto de Lei 3.516/1989); a restrição à liberdade provisória (art. 13 do Projeto de Lei 3.516/1989); a extensão do prazo de prisão processual para 180 dias (art. 14 do Projeto de Lei 3.516/1989); a proibição de apelar em liberdade (art. 16 do Projeto de Lei 3.516/1989); e a determinação de início de cumprimento de pena em regime fechado (art. 17 do Projeto de Lei 3.516/1989).

Além disso, criavam-se instrumentos de persuasão à delação premiada (art. 11 do Projeto de Lei 3.516/1989) e à confissão espontânea (art. 12 do Projeto de Lei 3.516/1989), na trilha do processo penal utilitarista, adotado como modelo. Logo, supervalorizava-se a interceptação telefônica (art. $2^{o}$, IV do Projeto de Lei 3.516/1989) e cedia-se à tentação do sigilo, ao se afirmar possível 'preservar as fontes de informação' (art. $4^{o}$ do Projeto de Lei 3.516/1989) ${ }^{\prime, 32}$ (grifei)

O texto final, como se verá, com redação alterada posteriormente pela lei 10.217/2001, positivou, quase que inteiramente, as restrições aos direitos processuais descritos no PL 3.516/1989, com exceção da duração do processo com o réu preso e a questão do sigilo para abarcar tão somente a autorização judicial que autorizar a infiltração. Sigilo este que tem claro intuito de preservar a integridade física deste agente, bem como possibilitar uma eficaz coleta de provas, com ressalva, no entanto, de que deverá extinguir-se com o fim da medida. Portanto, uma vez colhida as provas (fase pré-processual), não mais se sustenta a necessidade da infiltração, devendo cessar antes do oferecimento da denúncia, o que possibilitará, dentro do processo, o exercício da ampla defesa e do contraditório.

Apesar da Lei. 9.034/1995 manter as restrições a direitos e garantias, retirou o conceito de organização criminosa que constava no projeto inicial, acarretando, como consequência lógica, diante do princípio da legalidade, a perda de eficácia de todos estes dispositivos até que se defina em lei este conceito.

\footnotetext{
${ }^{32}$ PITOMBO, Antonio Sergio Altieri de Moraes. Organizações criminosas: nova perspectiva do tipo legal. São Paulo: Revista dos Tribunais, 2009. p. 91.
} 


\begin{abstract}
"Se as leis do crime organizado no Brasil (Lei $9.034 / 95$ e 10.217/01), que existem para definir o que se entende por organização criminosa, não nos explicaram o que é isso, não cabe outra conclusão: desde 12.04.01, perderam eficácia todos os dispositivos legais fundados nesse conceito que ninguém sabe o que é. São eles: art. $2^{o}$, inc. II (flagrante prorrogado), $4^{o}$ (organização da polícia judiciária), $5^{\circ}$ (identificação criminal), $6^{\circ}$ (delação premiada), $7^{\circ}$ (proibição de liberdade provisória) e $10^{\circ}$ (progressão de regime) da Lei 9.034/95, que só se aplicam para as (por ora, indecifráveis) 'organizações criminosas'.

É caso de perda de eficácia (por não sabermos o que se entende por organização criminosa), não de revogação (perda de vigência). No dia em que o legislador revelar o conteúdo desse conceito vago, tais dispositivos legais voltarão a ter eficácia. Por ora, continuam vigentes, mas não podem ser aplicados. "33
\end{abstract}

Não obstante os inúmeros problemas no Projeto de Lei, sendo a questão da inconstitucionalidade parcial a mais importante, após ser acatado o pedido de urgência para votação, o Projeto de Lei 3.516 foi aprovado, em 29 de junho de 1990, pela Câmara dos Deputados sem qualquer debate, sendo remetido, no dia seguinte, ao Senado Federal. Vislumbra-se, aqui, a urgência com que queriam a aprovação de uma lei que positivasse as restrições dos direitos e garantias processuais, sob o pretexto de se combater as organizações criminosas.

Inexplicavelmente, como chama à atenção Antonio Sérgio Altieri de Moraes Pitombo ${ }^{34}$, o Relator do PL, Deputado Federal Roberto Jefferson, limitou-se a dizer: "Meu voto é pela constitucionalidade, boa técnica legislativa e adequada redação. No mérito, atende aos mais modernos institutos investigatórios, é instrumento legal indispensável para o combate ao crime organizado. Daí porque também quanto ao mérito meu parecer é pela aprovação.

Sendo recebido no Senado, o PL 3.516 fora renomeado para de Projeto de Lei da Câmara 62 e, rapidamente, a técnica questionável utilizada para descrever uma organização criminosa chamou a atenção dos senadores, que, ao invés de buscarem sua correta definição, tendo à frente o senador Jutahy Magalhães, preferiram a saída menos trabalhosa, porém

\footnotetext{
${ }^{33}$ GOMES, Luiz Flávio. Crime organizado: que se entende por isso depois da Lei n. 10.217, de 11.04.01? (Apontamentos sobre a perda de eficácia de grande parte da Lei 9.034/95). Disponível em <http://www.ibccrim.org.br/site/artigos/_imprime.php?jur_id=928>. Acesso em 26 ago. 2009.

${ }^{34}$ PITOMBO, Antonio Sergio Altieri de Moraes. Organizações criminosas: nova perspectiva do tipo legal. São Paulo: Revista dos Tribunais, 2009. p. 92.
} 
juridicamente absurda, de modificar o artigo $2^{\circ}$ e alterar o art. 288 do Código Penal ${ }^{35}$, retalhando e emendando as leis (como é característica do direito penal de emergência) e embaraçando conceitos que não se confundem juridicamente, ainda que guardem remota semelhança.

Com as duas emendas apresentadas, assim ficaria o texto:

"Emenda 1 do relator

(...)

'Art. 2. ${ }^{\circ}$ Considera-se crime organizado o conjunto dos atos delituosos que decorram ou resultam das atividades de quadrilha ou bando, definidos no $\$ 1 .^{\circ} d o$ art. 288 do Decreto-Lei 2.848, de 7 de dezembro de 1940 - Código Penal'.

Emenda 2 do relator

'Art. 3. ${ }^{\circ} \mathrm{O}$ art. 288 do Decreto-Lei 2.848, de 7 de dezembro de 1940 - Código Penal - passa a ter a seguinte redação:

Art. $288(\ldots)$

$\$ 1 .^{\circ}$ Se a quadrilha ou bando serve-se de estruturas ou é estruturada ao modo de sociedades, associações, fundações, empresas, grupos de empresas, unidades, forças militares, órgãos ou entidades públicas ou que prestam serviço público:

Pena - reclusão, de 2 (dois) anos a 5 (cinco) anos.

$\$ 2 .{ }^{\circ}$ A pena aplica-se em dobro, se a quadrilha ou bando é armado, ${ }^{, 36}$

Outra questão que sofreu alteração no senado fora a previsão da infiltração do agente policial, entretanto, o Senador Amir Lando, embora tenha identificado a necessidade de se estabelecer determinadas regras, foi infeliz no texto proposto, por demais simplista. Pelo parecer, admitir-se-ia a infiltração do agente da polícia especializada em quadrilhas ou bandos, excluindo-se a ilicitude, contudo, apenas quanto ao crime previsto no art. 288 do CP, por consequência, todos os demais atos seriam típicos, ilícitos e culpáveis.

A votação do PLC 62 foi adiada, por iniciativa do senador Josaphant Marinho, diante da segunda proposta constante no parecer do senador Amir

\footnotetext{
${ }^{35}$ Art. 288 - Associarem-se mais de três pessoas, em quadrilha ou bando, para o fim de cometer crimes:

Pena - reclusão, de um a três anos.

Parágrafo único - A pena aplica-se em dobro, se a quadrilha ou bando é armado.

${ }^{36}$ PITOMBO, Antonio Sergio Altieri de Moraes. Organizações criminosas: nova perspectiva do tipo legal. São Paulo: Revista dos Tribunais, 2009. p. 92. Apud. Diário do Congresso Nacional, Brasília, seção II, p .2029, 28.04.1992.
} 
Lando que tinha como objetivo submeter à aplicação da infiltração do agente da policia especializada à autorização judicial.

Como se verá adiante, a ausência da obrigação de submeter o requerimento de infiltração para ser apreciado pelo poder judiciário constituirá motivo para o veto presidencial, retirando-se do ordenamento jurídico, até a edição da lei 10.217/2001, a figura do agente infiltrado.

Enquanto aguardava votação, fora encaminhado, pelo senador José Paulo Bisol Substitutivo ao PLC 62, nos seguintes termos:

"Art.1. ${ }^{\circ}$ Esta lei define e regula os meios de prova e procedimentos investigatórios permitidos nos inquéritos e processos que versarem sobre crime organizado.

Art. $2 .^{\circ}$ Considera-se crime organizado aquele que de algum modo coopera com os fins ou participa das atividades das quadrilhas ou bandos ou organizações previstas pelo art. 288 do Código Penal.

Art. 3. ${ }^{\circ} \mathrm{O}$ artigo 288 do Código Penal passa a ter a seguinte redação:

'Art. 288. Participar de quadrilha, bando ou organização que se serve das estruturas ou é estruturada ao modo de sociedades, associações, fundações, empresas, grupo de empresas, unidades ou forças militares, órgãos, entidades ou serviços públicos, concebidas qualquer que seja o princípio, pretexto, motivação ou causa, para cometer crime ou alcançar objetivos cuja realização implica a prática de ilícitos penais.'

Pena - reclusão, de um a três anos

Parágrafo único. A pena aplica-se em dobro, se a quadrilha ou bando é armado. ",37

Peca o Substitutivo ao diferenciar organização de quadrilha ou bando, mas de mantê-los vinculados ao mesmo tipo penal, negando, portanto, sua autonomia e mantendo a confusão de termos que não se confundem juridicamente.

Verifica-se, ademais, a manutenção errada da nomenclatura utilizada, sendo cometido o impropério de dizer que "crime organizado é aquele que de algum modo coopera com os fins ou participa das atividades das quadrilhas ou bandos ou organizações". Ora, crime, seja ele organizado

\footnotetext{
${ }^{37}$ PITOMBO, Antonio Sergio Altieri de Moraes. Organizações criminosas: nova perspectiva do tipo legal. São Paulo: Revista dos Tribunais, 2009. p. 93-94. Apud. Diário do Congresso Nacional, Brasília, seção II, p .9358, 24.11.1992.
} 
ou desorganizado é produto humano, decorre de ações humanas, portanto, jamais poderá ser o crime o sujeito da cooperação ou participação.

Contudo, ainda que tenha aguardado um ano para a sua votação, o que se viu foi a aprovação do substitutivo livre de qualquer debate.

Sobre o assunto aqui tratado, claríssimos são os dizeres de Antonio Sergio Pitombo:

"Outra vez, sem maior discussão, em 19 de novembro de 1993, os senadores aprovaram o Substitutivo - quase um ano depois de sua apresentação pelo Senador José Paulo Bisol. Depois de apresentada a redação do vencido para o turno suplementar (Parecer 432, de 1993), Jutahy Magalhães sugeriu a supressão do art. $2^{\circ}$, sob o seguinte argumento: 'Está dito, neste preceito, que considera-se como 'crime organizado aquele que de algum modo coopera com os fins ou participa das atividades das quadrilhas, bandos ou organizações previstas pelo art. 288 do Código Penal.' Ora, crime não coopera com outro crime. Há impropriedade contextual. Mais: o artigo 288 do CP não prevê organizações, mas define o crime de quadrilha ou bando, que é a societas sceleris, vale dizer, a organização de delinqüentes disposta estavelmente, à realização de ilícitos. "38

Insta alertar para o erro do senador Jutahy Magalhães ao afirmar que o artigo 288 do $\mathrm{CP}^{39}$ prevê a organização de "delinqüentes disposta estavelmente". O que há, é uma cumulação subjetiva estável com o fim de cometerem crimes, não havendo necessidade de qualquer forma de organização; não é necessária a hierarquia ${ }^{40}$, nem mesmo divisão de tarefas entre os participantes ${ }^{41}$. A conduta típica, segundo Damásio de Jesus consiste "na associação de, no mínimo, quatro pessoas, com o fim específico de cometimento de crimes" 42 , não configurando a cumulação subjetiva momentânea que objetive o cometimento de ilícitos, caso de

\footnotetext{
${ }^{38}$ PITOMBO, Antonio Sergio Altieri de Moraes. Organizações criminosas: nova perspectiva do tipo legal. São Paulo: Revista dos Tribunais, 2009. p. 94

${ }^{39} \mathrm{O}$ crime tipificado pelo art. 288 é classificado pela doutrina como: crime comum, formal, de forma livre, comissivo e, excepcionalmente, omissivo impróprio ou comissivo por omissão, permanente, de perigo comum abstrato, plurissubjetivo, plurissubsistente e que não admite tentativa em razão da estabilidade e permanência requeridas, que somente se verifica com o cometimento de mais de um crime. Tem como núcleo do tipo o verbo associar, isto é, "reunir-se em sociedade, agregar-se ou unir-se", aperfeiçoando-se com o momento associativo. Exige-se para a sua consumação a presença de 4 ou mais integrantes, independentemente de serem todos imputáveis ou não. Exige-se, ainda, a finalidade especifica que é a vontade de se cometerem crimes determinados.

${ }^{40}$ JESUS, Damásio E. de. Código Penal Anotado. 17ª ed. São Paulo: Saraiva, 2005. p. 889.

${ }^{41}$ Ibid.

${ }^{42}$ Ibid. p. 890
} 
aplicação da norma de co-autoria e participação contida no artigo $29^{43}$ do $\mathrm{CP}^{44}$

Após as criticas sofridas, o senador Amir Lando, em novo parecer, propôs que crime organizado seria o conjunto de atos delituosos decorrentes, ou resultantes, das atividades da quadrilha ou bando, desde que estas se utilizassem de estruturas ou fossem estruturadas nos moldes sugeridos pelo senador Jutahy Magalhães, quando propôs a segunda emenda ao PLC 62, ficando assim aprovado, “com a ressalva do Senador Josaphant Marinho, o qual se absteve de votar o projeto de lei 'diante da incompatibilidade dele com o bom sistema da ordem jurídica brasileira"

De volta à Câmara, o Deputado Federal Miro Teixeira ofereceu Substitutivo risível, posicionando-se contra a alteração do artigo 288 do CP, sob a alegação de que criar-se-ia uma enorme confusão entre os estudantes de Direito que perderiam seus livros, códigos e comentários com a mudança de um único artigo. Deste modo, sugeriu a aprovação do projeto do Deputado Michel Temer em detrimento do Substitutivo aprovado pelo Senado, retratando-se em 06.04.1995, quando submeteu o Substitutivo do Senado à votação.

"O deputado federal Miro Teixeira, em 6 de abril de 1995, mudou o parecer anterior e submeteu o Substitutivo do Senado Federal à votação, com requerimento de destaques de supressão do artigo $2{ }^{\circ}$, referente à descrição do crime organizado, e do art. $3 .^{\circ}$, que modificava o tipo de quadrilha ou bando, do art. 288 do $C P$.

O mesmo deputado ainda pediu destaque para se retirar, entre os meios de investigação, 'o impedimento, a interrupção, a interceptação, a escuta e a gravação das comunicações telefônicas' (art. 4. ${ }^{\circ}$, III do Substitutivo ao Projeto de Lei da Câmara 62). Enfim, pleiteou destaque de supressão à alteração do art. 16 do CP (art. 14, Substitutivo ao Projeto de Lei da Câmara 62).

\footnotetext{
${ }^{43}$ Art. 29 - Quem, de qualquer modo, concorre para o crime incide nas penas a este cominadas, na medida de sua culpabilidade.

$\S 1^{\circ}$ - Se a participação for de menor importância, a pena pode ser diminuída de um sexto a um terço.

$\S 2^{\circ}$ - Se algum dos concorrentes quis participar de crime menos grave, ser-lhe-á aplicada a pena deste; essa pena será aumentada até metade, na hipótese de ter sido previsível o resultado mais grave.

${ }_{4}$ JESUS, Damásio E. de. Código Penal Anotado. $17^{\text {a }}$ ed. São Paulo: Saraiva, 2005. p. 890.

${ }^{45}$ PITOMBO, Antonio Sergio Altieri de Moraes. Organizações criminosas: nova perspectiva do tipo legal. São Paulo: Revista dos Tribunais, 2009. p. 95. Apud. Diário do Congresso Nacional, Brasília, seção II, p .3149, 16.06.1994.
} 
Em seguida, Miro Teixeira fez emendas de redação à ementa e, no tocante ao art. $1 .^{o}$, substituiu a expressão crime organizado por quadrilha ou bando. Ambas as emendas restaram acolhidas pelos demais parlamentares. Desse modo, votou-se a redação final, que acabou aprovada. ${ }^{46, "}$

Antes da promulgação, contudo, o inciso I do artigo $2^{\circ}$ da Lei 9.034, que disciplinava a infiltração do agente policial, com o texto do senador Amir Lando, sofreu veto da presidência, Mensagem $483^{47}$, acatando o parecer do Ministério da Justiça que alegou violação do interesse público a possibilidade da infiltração ocorrer sem a prévia autorização judicial, sendo ainda mais grave a expressa autorização legal para que o agente cometa crime, pré-excluída, no caso, a antijuridicidade, o que afrontaria os princípios adotados pela sistemática do $\mathrm{CP}$.

Após inúmeras confusões conceituais, em maio de 1995, entrou em vigor a Lei. 9.034, que embora tivesse a função de dispor sobre os meios operacionais para a prevenção e repressão de ações praticadas por crimes organizados, foi incapaz de atingir seu objetivo e definir o que seria uma organização criminosa, deste modo, se contentou em regular os meios de prova e procedimentos investigatórios que versassem sobre crime resultante de ações de quadrilha ou bando, como se juridicamente fossem a mesma coisa!

Diante deste quadro, formularam-se diversas teorias interpretativas buscando dar efetividade a lei em questão, solidificando-se duas correntes. A primeira, que considerava organização criminosa sinônimo de quadrilha ou bando, cuja William Douglas e Fernando Capez eram adeptos, defendia

\footnotetext{
${ }^{46}$ PITOMBO, Antonio Sergio Altieri de Moraes. Organizações criminosas: nova perspectiva do tipo legal. São Paulo: Revista dos Tribunais, 2009. p. 96. Apud. Diário do Congresso Nacional, Brasília, seção I, p .5632, 5634-5635 e 5635, 06.04.1995.

${ }^{47}$ A mensagem 483 tem a seguinte redação: Comunico a Vossa Excelência, que nos termos do parágrafo $1^{\circ}$ do artigo 66 da Constituição Federal, decidi vetar parcialmente o Projeto de Lei $n^{\circ}$ 3.516, de 1989 (n62/90 no Senado Federal), que "Dispõe sobre a utilização de meios operacionais para a prevenção e repressão de ações praticadas por organizações criminosas”.

É o seguinte o teor do dispositivo ora vetado por contrariar o interesse público:

"Art. $2^{\circ}$ ,"

I - a infiltração de agentes da polícia especializada em quadrilhas ou bandos, vedada qualquer coparticipação delituosa, exceção feita ao disposto no art. 288 do Decreto-Lei no 2.848 , de 7 de dezembro de 1940 - Código Penal de cuja ação se preexclui, no caso a antijuridicidade;
} 
que o maior ou menor grau de sofisticação não era requisito legal, portanto, aplicar-se-ia a Lei 9.034/95 a qualquer delito proveniente de quadrilha ou bando, não obstante a ementa dissesse uma coisa e o artigo $1^{\circ}$ outra.

Insta transcrever a justificativa adotada por Fernando Capez para sua filiação doutrinária.

"É claro que tal equiparação foi inadequada, mas esta havia sido a vontade da Lei: tratar como idênticas a quadrilha ou bando, agrupamentos sem nenhuma sofisticação, complexidade ou estruturação diferenciada (a chamada 'criminalidade massificada'), e a organização criminosa, muito mais complexa, pertencente ao gênero criminalidade sofisticada. Foi, porém, o que o texto expresso da lei determinara. ${ }^{48,}$

Interessante verificar que o próprio autor considerava inadequada a sua teoria, mas se resignava sob o argumento de que esta tinha sido a vontade da lei. Entretanto, embora tenha sido este o texto final aprovado pelo Congresso Nacional, como se viu neste capítulo, não fora esta a intenção original. Originalmente, buscava-se conceituar organização criminosa, ainda que o texto tenha pecado pela redação que acabava por traduzir uma indefinição.

A segunda posição, defendida por Luiz Flávio Gomes, no que chamou de interpretação construtiva, ainda que ele próprio questionasse a sua validade, dizia que "o correto âmbito de incidência da lei em destaque estaria constituído pelas organizações criminosas, de cuja composição fariam parte os dados típicos do delito previsto no artigo 288 do CP (quadrilha ou bando, que era mencionado no art. $1^{\circ}$ primitivo) mais alguns requisitos extras (organização, planejamento, hierarquia do grupo etc). ${ }^{, 49}$

Todavia, os adeptos desta tese jamais chegaram a um consenso sobre quais seriam os requisitos extras, variando ao alvedrio do exegeta.

\footnotetext{
${ }^{48}$ CAPEZ, Fernando. Curso de Direito Penal: Legislação Penal Especial. vol. 4. $4^{\mathrm{a}}$ ed. São Paulo: Saraiva, 2009. p. 244.

${ }^{49}$ GOMES, Luiz Flávio. Crime organizado: que se entende por isso depois da Lei $n .10 .217$, de 11.04.01? (Apontamentos sobre a perda de eficácia de grande parte da Lei 9.034/95). Disponível em <http://www.ibccrim.org.br/site/artigos/_imprime.php?jur_id=928> Acesso em 26 ago. 2009.
} 
Verifica-se, portanto, que independentemente da posição adotada, a única unanimidade entre a doutrina era o desconforto com a lei que fora promulgada.

Neste diapasão, um magistrado, adepto de uma determinada linha de exegese, poderia conceder liberdade provisória para o acusado, por entender que faltava o requisito extra "X", e por isso não haveria incidência da lei em tela, enquanto outro magistrado, muitas vezes da mesma comarca, porém adepto de outra linha de pensamento, apreciando um pedido de liberdade provisória idêntico, poderia aplicar o artigo $7^{05051}$ da Lei. 9.034/1995 e indeferir o pedido por entender que o legislador havia criado um sinônimo entre quadrilha ou bando e organização criminosa.

Esta subjetividade era apta, portanto, a produzir diversos casos de injustiça, ou de perseguições (atos de abuso de poder), possibilitando a aplicação do Direito Penal do Autor.

Conceituando Direito penal do autor e comparando-o com o Direito penal do fato, através de uma dialética com as normas constitucionais, trazemos, a seguir, as lições de Joaquim Leitão Júnior:

"O direito penal do autor consiste na norma penal que se preocupa com quem o agente é, e não com o fato por ele praticado. Essa visão é absolutamente inconstitucional, e mais curioso ou paradoxo que pareça, ainda existe no nosso ordenamento este verdadeiro antagonismo. Exemplo flagrante é, v.g., o fato contravencional da mendicância e da vadiagem que pune o agente por quem é e não pela conduta tipificada como contravenção.

Já no direito penal dos fatos, o direito repressivo se preocupa tão-somente com os fatos delituosos praticados pelo agente. Essa concepção é pacificamente correta, porquanto se apresenta harmonicamente com o espírito traçado na Constituição Federal e com a própria sistematização do ordenamento jurídico penal em si. $^{52}$,

No ano 2000, fora enviado ao Presidente da República projeto de lei (3.275/2000) com objetivo de alterar a lei de crime organizado, de autoria

\footnotetext{
${ }^{50}$ Art. $7^{\circ}$ Não será concedida liberdade provisória, com ou sem fiança, aos agentes que tenham tido intensa e efetiva participação na organização criminosa.

${ }^{51}$ A questão da inconstitucionalidade já foi por nós abordada na nota 26 deste trabalho.

${ }^{52}$ LEITÃO JÚNIOR, Joaquim. Qual a diferença entre o direito penal do autor e o direito penal dos fatos? Disponível em <http://www.lfg.com.br/public_html/article.php?story=20080918164606664> Acesso em 05 jun. 2010.
} 
do Ministro de Estado de Justiça, José Gregori e do Chefe do Gabinete de Segurança institucional da Presidência da República, Alberto Mendes Cardoso.

Dentre as mudanças, pretendia-se mudar o texto do artigo $1^{\circ}$, diferenciando, cristalinamente, quadrilha ou bando e organização criminosa, inserindo ainda a figura da associação criminosa. Falhou, contudo, ao manter no texto o crime de quadrilha ou bando.

Tinha, ainda, como objetivo a inserção no texto legal da possibilidade de interceptação ambiental e ressuscitar a infiltração policial, pleitos nitidamente influenciados pelo Direito Comparado.

"Propuseram-se, então, a interceptação ambiental e a infiltração policial, pois, segundo tal documento: 'Entre as diversas medidas que têm sido adotadas em vários países no combate ao crime organizado, a infiltração controlada e a escuta ambiental vêm se destacando pelos resultados altamente positivos. Numerosas operações internacionais têm sido realizadas com sucesso graças ao uso de informações obtidas por agentes infiltrados e mediante escutas ambientais' (art. 1. ${ }^{\circ}$ do Projeto de Lei 3.275/2000) ${ }^{53}$." (grifei)

O risco, contudo, de importar institutos de ordenamentos jurídicos alienígena é sempre alto, visto que demanda uma profunda analise e adequação aos princípios constitucionais e infraconstitucionais que regem o nosso ordenamento, caso contrário, editar-se-á leis inconstitucionais ou de eficácia restrita.

Na câmara, sob o argumento de que o Projeto de Lei do Executivo, ao incluir as expressões "garantia da segurança e estabilidade institucional", de forma vaga, criava-se o risco de ações de espionagem contra movimentos sociais e políticos e por medo de uso indevido das informações obtidas durante a investigação, vez que não havia regras claras regulamentando a matéria, foi publicado, no dia 12 de agosto de 2000, Substitutivo ao PL proveniente do Poder Executivo.

Falando sobre o assunto, Antonio Sergio Altieri Pitombo aduz que:

\footnotetext{
53 PITOMBO, Antonio Sergio Altieri de Moraes. Organizações criminosas: nova perspectiva do tipo legal. São Paulo: Revista dos Tribunais, 2009. p. 97.
} 
"As mudanças no Projeto almejavam regrar, em princípio, o sigilo e a guarda de informações, obtidas por meio de tais procedimentos de investigação. Há dispositivo que chama atenção no Substitutivo pela redação: ' $\$ 7^{\circ}$ Os procedimentos previstos no caput serão processados no estrito respeito aos direitos, liberdades e garantias fundamentais da pessoa humana.

Em verdade,os parlamentares pressentiam os riscos da aplicação da lei, bem como já aquilatavam o amplo espectro de arbitrariedades que viriam a ser cometidas, sob o manto de se perseguir o crime organizado. $O$ uso freqüente, no Projeto de Lei, da expressão 'garantia da segurança e estabilidade institucional' apontava para o discurso, importado, do perigo e da emergência do crime organizado. ${ }^{54,}$

Concordamos com o medo compartilhado pelos legisladores, embora entendamos que tais riscos já se encontravam na lei que se pretendia mudar. Infelizmente, a ressalva contida no $\S 7^{\circ}$, cuja observância deveria ser regra geral e irrestrita ao se falar em procedimentos investigatórios, não havendo necessidade de previsão expressa, mostra-se tão esquecida na nossa sociedade que a sua inserção, de forma expressa, não se mostra um absurdo. Ademais, conforme tratamos no capitulo anterior, o discurso do perigo (discurso do medo), não é de exclusividade dos países estrangeiros. Padecemos do mesmo mal.

Outro obstáculo a aprovação consistia no debate sobre a antijuridicidade, na infiltração do agente policial, do crime de quadrilha ou bando. Contudo, com a exclusão da expressão "garantia da segurança e estabilidade institucional" e do dispositivo que previa a exclusão da ilicitude, o PL, com redação final do Deputado Federal Luiz Antônio Fleury Filho, foi aprovado na Câmara dos Deputados.

A confusão acerca da definição de organização criminosa, misturando-se conceitos juridicamente autônomos, aliás, continuou, como se extrai do discurso do Senador Romeu Tuma, que fora designado para relatar o PL.

"No Senado Federal, Romeu Tuma relatou o Projeto (Projeto de Lei da Câmara 58/2000 - PL 3.275/2000), observou que: 'Inicialmente, acrescenta ao texto vigente do art. $1 .^{\circ}$ da Lei 9.034/1995 a expressão 'ou organizações ou

\footnotetext{
${ }^{54}$ PITOMBO, Antonio Sergio Altieri de Moraes. Organizações criminosas: nova perspectiva do tipo legal. São Paulo: Revista dos Tribunais, 2009. p. 97
} 
associações criminosas de qualquer tipo', como alternativa ao conceito de quadrilha ou bando. Ora, quadrilha ou bando é a associação de mais de três pessoas (...) para o fim de cometer crimes (srt. 288 do CP). Vê-se, claramente, que 'organizações ou associações criminosas de qualquer tipo' estarão, quase que na totalidade, incluídas no conceito de quadrilha ou bando. A associação de duas pessoas para o cometimento de um delito, melhor que ser considerada como uma 'associação criminosa', é, sim, um caso simples de concurso de agentes (art.29 do CP). Três pessoas associadas com intenções criminosas, com mais um agente infiltrado, constituem uma quadrilha ou bando. Logo, a expressão cujo acréscimo é pretendido nos parece expletiva e, por não ter definição jurídica, só concorre para a indefinição e imprecisão do texto. ${ }^{~} 55$

Note-se que o Senador Romeu Tuma limita-se, em sua análise sobre os conceitos de quadrilha ou bando, associação ou organização criminosa, a verificar o número de participantes, descartando todos os demais elementos diferenciadores, tais como estrutura, hierarquia, influência, mediante extorsão ou corrupção, em setores do Poder Público, estrutura de empresa etc.

Ademais, conforme se extrai do artigo $35^{56}$ da lei $11.343 / 2006$, não prevaleceu no nosso ordenamento o entendimento, equivocado, do Senador sobre o que seria uma associação criminosa. Há questões que, concomitantemente com o número de sujeitos ativos, devem ser verificadas para, no caso concreto, saber se aquela conduta foi praticada por uma associação delitiva ou por um mero concurso de pessoa.

Tentou-se, novamente regulamentar a questão dos atos provenientes da infiltração, positivando a antijuridicidade, desde que não se verificasse um abuso ou desvio de finalidade, caso em que responderia penalmente quem o perpetrou.

\footnotetext{
${ }^{55}$ PITOMBO, Antonio Sergio Altieri de Moraes. Organizações criminosas: nova perspectiva do tipo legal. São Paulo: Revista dos Tribunais, 2009. p. 99. Apud. Diário do Congresso Nacional, Brasília, p. 22.467, 15.11.2000.

${ }^{56}$ Art. 35. Associarem-se duas ou mais pessoas para o fim de praticar, reiteradamente ou não, qualquer dos crimes previstos nos arts. 33, caput e $\S 1^{\circ}$, e 34 desta Lei:

Pena - reclusão, de 3 (três) a 10 (dez) anos, e pagamento de 700 (setecentos) a 1.200 (mil e duzentos) dias-multa.

Parágrafo único. Nas mesmas penas do caput deste artigo incorre quem se associa para a prática reiterada do crime definido no art. 36 desta Lei.
} 
Em sua tramitação no Senado, as emendas propostas foram acatadas, prevalecendo a aparente ficção jurídica de que quadrilha ou bando é sinônimo de organização criminosa, vez que, ao se retirar a expressão "ou organização ou associação criminosa de qualquer tipo, manteve-se o texto da antiga Lei 9.034/1995, lei esta que se pretendia mudar.

Em boa hora, a Câmara rejeitou a emenda que suprimia do texto legal a diferenciação que se pretendia positivar, pondo fim às inúmeras discussões doutrinarias que criavam teses interpretativas que não agradavam ninguém, conforme já exposto. Não foi aceita, ainda, a emenda que tratava da antijuridicidade dos atos cometidos durante a infiltração, sendo este o texto final que foi sancionado pelo Presidente da República.

\section{2 - O princípio da Legalidade e sua função de restrição dos atos Estatais}

Dizer que vivemos em um Estado de Direito significa, em outras palavras, afirmar que o Estado deve se submeter ao Direito, isto é, o ordenamento jurídico deve sempre prevalecer sobre os atos estatais, controlando e evitando abusos lesivos aos cidadãos. Neste sentido, o princípio da legalidade exerce papel fundamental, reservando à lei os comandos direcionados aos súditos e limitando os atos do Estado, que somente poderá agir quando e nos moldes previstos pela lei.

Vejamos as importantes lições do penalista Rogério Greco:

"Estado de direito e princípio da legalidade são sois conceitos intimamente relacionados, pois que num verdadeiro Estado de Direito, criado com a função de retirar o poder absoluto das mãos do soberano, exige-se a subordinação de todos perante a lei. ${ }^{57,}$

Sua origem, ainda que não haja um consenso entre os juristas, remonta a Magna Carta Inglesa, de 1215, do Rei João Sem Terra, sendo, contudo, na Revolução Francesa que este adquiriu força e preencheu a posição de cardeal princípio do Direito Penal.

\footnotetext{
${ }^{57}$ GRECO, Rogério. Curso de Direito Penal. $7^{\mathrm{a}}$ ed. Rio de Janeiro: Impetus, 2006. p. 97.
} 
Insta ressaltar que, em Estados Constitucionais de Direito, como o nosso, a Constituição Federal da República é mais do que uma carta de organização dos órgãos públicos, definindo e repartindo competências, mas verdadeiro escudo dos cidadãos contra abusos cometidos pelos governantes. Se o Estado se submete ao ordenamento jurídico, este tem como ponto irradiador de eficácia e validade a Constituição Federal.

É comum, nos livros de doutrina de Direito Penal, ao se abordar o princípio da legalidade, os autores fazerem referencia ao inciso XXXIX do artigo $5^{\circ}$ da $\mathrm{CF}$, que diz que "não há crime sem lei anterior que o defina, nem pena sem previa cominação legal" - norma constitucional, inscrita no rol de direitos e garantias fundamentais e, por conseguinte, nos termos do artigo $60, \S 4^{\circ}$, inciso IV, da $\mathrm{CF}^{58}$, imutável - com reprodução no artigo $1^{\circ}$ do Código Penal ${ }^{59}$.

Inegavelmente, um dos seus corolários é este apontado pela doutrina, no entanto, o princípio da legalidade é bem mais amplo do que proibir a imputação de certa conduta como crime ou a sua punição sem lei que os defina e as cominem.

Sua verdadeira face encontra-se no inciso II do artigo $5^{\circ}$ da CF que diz que "ninguém será obrigado a fazer ou deixar de fazer alguma coisa senão em virtude de lei". Nota-se que somente a lei pode obrigar o cidadão, em outras palavras, somente ela poderá criar obrigações para o indivíduo. Isto porque, por vivermos em sociedade somos obrigados a nos submetermos à vontade geral, todavia, esta somente se faz ouvir mediante leis que estejam em conformidade com os preceitos constitucionais.

Alexandre de Moraes, trazendo as lições de dois eminentes juristas afirma que:

\footnotetext{
${ }^{58}$ Art. $60(\ldots)$

$\S 4^{\circ}$ - Não será objeto de deliberação a proposta de emenda tendente a abolir:

(...)

IV - os direitos e garantias individuais.

${ }^{59}$ Art. $1^{\circ}$ - Não há crime sem lei anterior que o defina. Não há pena sem prévia cominação legal.
} 
"Conforme salientam Celso Bastos e Ives Gandra Martins, no fundo, portanto, o principio da legalidade mais se aproxima de uma garantia constitucional do que de um direito individual, já que ele não tutela, especificamente, um bem da vida, mas assegura ao particular a prerrogativa de repelir injunções que lhe sejam impostas, por uma ou outra via que não seja a da lei, pois como já afirmava Aristóteles, 'a paixão perverte os Magistrados e os melhores homens: a inteligência sem paixão - eis a lei ${ }^{\text {, }, 60}$

Portanto, ao se falar em princípio da legalidade, dentro do ordenamento constitucional brasileiro, não podemos nos limitar à ideia de que este apenas enseja a vedação de se criminalizar ou de se apenar quando ausente lei que preveja sua criminalização e/ou sua pena, devemos ter em mente que ele mostra-se muitíssimo mais amplo, vedando a estipulação de qualquer obrigação, leia-se, qualquer diminuição de direitos e liberdades gozadas e asseguradas pela nossa Constituição, quando inexistente lei que assim determine.

\section{3 - A questão do princípio da legalidade na Lei. 9.034/1995, com as modificações feitas pela Lei. 10.217/2001}

Conforme exaustivamente demonstrado, ao se tentar introduzir no país uma lei de ação contra os crimes perpetrados pelas organizações criminosas, nossos legisladores falharam, pois não conseguiram defini-los. Desejavam combater um inimigo tido como poderoso, considerado fonte de quase toda a criminalidade brasileira, sendo esta a fundamentação para se endurecer a lei e prever novos mecanismos de investigação e segregação social.

$\mathrm{O}$ que se conseguiu, contudo, foi uma lei que previa meios de investigação e produção de provas contra crimes cometidos por quadrilhas ou bandos, carente de qualquer sofisticação, impossibilitada de se esquivar da aplicação da lei penal já existente, por serem, tão somente, uma aglutinação de pessoas com o fim de cometerem ilícitos, ao contrário das organizações criminosas, que, de fato, detêm poder econômico e político,

\footnotetext{
${ }^{60}$ MORAES, Alexandre de. Direito Constitucional. $20^{\mathrm{a}}$ ed. São Paulo: Atlas, 2006. p. 36.
} 
não sendo raros os casos de exercerem influencia dentro do próprio aparelho estatal.

Conforme citado anteriormente ${ }^{61}$, diante deste fracasso, tentou-se buscar uma tese interpretativa que possibilitasse a aplicação da lei. Duas vertentes se formaram, a primeira que entendia que a lei havia criado uma ficção jurídica colocando como sinônimos os conceitos de quadrilha ou bando e organizações criminosas.

A esta tese, Eduardo Araújo Silva tece duras críticas: "a falta de distinção levou ao se afirmar que todo caso de quadrilha permitiria a aplicação da Lei 9.034/1995, o que afrontaria ao princípio da proporcionalidade. ${ }^{62,}$

Já a segunda, entendia que a lei somente poderia ser aplicada àquelas quadrilhas ou bandos que tivessem elementos específicos, não havendo, contudo, consenso sobre quais seriam estes elementos.

Não é difícil imaginar o caos gerado pela lei. A injustiça era flagrante, vez que a repressão penal poderia ser mais dura ou mais branda, dependendo da corrente doutrinária a que se filiasse o magistrado que julgasse a causa.

Ao menos sabíamos o que era uma quadrilha ou bando, e deste conceito não se podia fugir. Ainda que peguemos a teoria que ampliava o conceito de quadrilha ou bando, verificar-se-á que se partia de um conceito definido e, ademais, ao buscar elementos específicos para a sua incidência, buscava-se a essência da lei, assim como inexistia danos aos direitos do acusado. Havia, poder-se-ia falar, uma interpretação extensiva in bonam partem, o que se mostra condizente com o Direito Penal e com o ordenamento constitucional.

\footnotetext{
${ }^{61}$ Vide capítulo 2, item 2.1.

${ }^{62}$ SILVA, Eduardo Araújo. Crime organizado: procedimento probatório. São Paulo: Atlas, 2009. p.39.
} 
Com a inserção da expressão "organização ou associação criminosa de qualquer tipo" ao artigo $1^{\circ}$, pela Lei $10.217 / 01^{63}$, o cenário mudou. Há inegavelmente, ainda que vozes insignificantes se insurjam contra o fato, diferenciação legal de quadrilha ou bando, associação criminosa e organização criminosa. Como as duas primeiras formas associativas encontram-se tipificadas no nosso ordenamento, sabe-se, sem sombra de dúvidas, o que sejam, contudo, a ultima permanece indefinida em nosso Direito.

Nas lições de Luiz Flávio Gomes sobre o tema, podemos ver claramente o que se afirma, vejamos:

"Pelo texto atual (Lei 11.217/2001) a lei incide nos ilícitos decorrentes de: (a) quadrilha ou bando; (b) organização criminosa; (c) associação criminosa.

Como se percebe, com o advento da Lei 10.217/01, estão perfeitamente delineados três conteúdos diversos: organização criminosa (que está enunciada na lei, mas não tipificada no nosso ordenamento jurídico), associação criminosa (ex.: Lei antidrogas - Lei 11.343/2006, art. 35; Lei 2.889/56, art. $2^{\circ}$ : associação para prática de genocídio) e quadrilha ou bando (CP, art. 288).

Quadrilha ou bando sabemos o que é (CP, art. 288); associações criminosas (ex.: Lei antidrogas, art. 35; Lei 2.889/56, art. $2^{\circ}$ ) sabemos o que é. Mas o que se entende por organização criminosa?

Não existe em nenhuma parte do nosso ordenamento jurídico (válido) a definição de organização criminosa. Para esse efeito, como veremos logo abaixo, não vale a Convenção de Palermo.

Cuida-se, portanto, de um conceito vago, totalmente aberto, absolutamente poroso. Considerando-se que (diferentemente do que ocorria antes) o legislador não ofereceu nem sequer a descrição típica mínima do fenômeno, só nos resta concluir que, nesse ponto, a lei (9.034/95) passou a ser letra morta. Organização criminosa, portanto, hoje, no ordenamento jurídico brasileiro, é uma alma (uma enunciação abstrata) em busca de um corpo (de um conteúdo normativo, que atenda o princípio da legalidade). ${ }^{64}$ "(grifos no original)

Claro está que a Lei 9.034/1995 não traz nenhuma norma penal incriminadora; não tem intuito de criar novos crimes, preocupando-se com aqueles que decorrem destas cumulações subjetivas. Em verdade, trata-se de lei cujas normas têm basicamente natureza processual penal, logo, a princípio, pode-se afirmar que o princípio da legalidade aqui não se aplica.

\footnotetext{
${ }^{63}$ Art. $1^{\circ}$ Esta Lei define e regula meios de prova e procedimentos investigatórios que versem sobre ilícitos decorrentes de ações praticadas por quadrilha ou bando ou organizações ou associações criminosas de qualquer tipo.

${ }^{64}$ GOMES, Luiz Flávio. Que Se Entende por Crime Organizado (Parte 1). Disponível em: <http://www.lfg.com.br/public_html/article.php?story=20100301093925108>. Acesso em 26 mar. 2010.
} 
São normas processuais penais, contudo, que remete o exegeta a termos de direito material. O conceito de quadrilha ou bando, associação criminosa ou organização criminosa são conceitos que cabem a lei material definir, são, em outras palavras, estranhos ao processo penal que se socorre, por conseguinte, da lei material.

Por sua vez, o artigo $1^{\mathrm{o}}$ da lei ${ }^{65}$ contém uma norma autorizadora, isto é, os demais artigos somente se sustentam com a sua existência, caso o artigo primeiro não trouxesse os parâmetros de aplicação, os demais não poderiam ser aplicados.

Nota-se, no entanto, a ausência de um dos parâmetros, conforme se demonstrou por este trabalho. Ao defini-los, esqueceu-se, o legislador, do principal, isto é, de dizer o que é organização criminosa para que se possam aplicar as demais regras que lhe fazem referencia.

Adiantamo-nos em dizer que não defendemos a idéia da tipificação do crime de organização criminosa, vez que seria mais um crime de perigo abstrato, típico do movimento de expansão do Direito Penal, e que violaria, manifestamente, o principio da ofensividade. Sobre o tema, remetemos o leitor ao capítulo seguinte.

Todavia, já deixamos clara nossa posição no sentido de que deixar a cargo do magistrado a definição do que seja organização criminosa somente gera injustiças e inseguranças. Relegar ao Poder Judiciário o preenchimento deste conceito fere o princípio da legalidade, vez que as demais normas que se utilizam desta expressão criam uma obrigação, isto é, restringem direitos do indivíduo, e, deste modo, somente a lei é que estaria autorizada a conceituar organização criminosa.

Não são de exclusividade da Lei 9.034/1995, como se demonstrará a seguir, mas quando analisamos os artigos que fazem menção às organizações criminosas, percebemos claramente que têm o efeito de

\footnotetext{
${ }^{65}$ Art. $1^{\circ}$ Esta Lei define e regula meios de prova e procedimentos investigatórios que versem sobre ilícitos decorrentes de ações praticadas por quadrilha ou bando ou organizações ou associações criminosas de qualquer tipo.
} 
restringir direitos e garantias individuais. Senão vejamos: o art. $5^{\circ}$ da Lei. $9.034 / 1995^{66}$ obriga a proceder à identificação criminal de todas as pessoas envolvidas com organizações criminosas, mesmo que sejam civilmente identificadas, o artigo $7^{\mathbf{0} 67}$ veda a concessão de liberdade provisória aos agentes que tenham "intensa e efetiva participação na organização criminosa", já o artigo $10^{68}$ prescreve que "os condenados por crimes decorrentes de organização criminosa iniciarão o cumprimento da pena em regime fechado".

Ora, quando obrigar o acusado a proceder à identificação criminal, se a própria constituição, no inciso LVIII do art. $5^{\circ 69}$ diz ser um direito do acusado, identificado civilmente, não se submeter à identificação criminal, ressalvada lei em contrário? Se não sabemos o que é uma organização criminosa, como saber se aquele acusado é seu integrante? Não parece lógico que a lei que irá restringir um direito fundamental, inafastável por emenda constitucional, deve obedecer ao princípio da legalidade contido no inciso II do artigo $5^{\mathbf{o}^{70}}$ ?

Não se pode argumentar que há lei criando a obrigação (Lei. 9.034/95), e com isto, cumprindo as exigências do princípio da legalidade. De fato, há lei, mas não se sabe quando se dá sua incidência, pois ela não determinou com clareza.

$\mathrm{O}$ artigo $7^{\mathbf{0}^{71}}$ vai além, e diz "intensa e efetiva participação na organização criminosa", se não sabemos o que é isto, como saber se o

\footnotetext{
${ }^{66}$ Art. $5^{\circ}$ A identificação criminal de pessoas envolvidas com a ação praticada por organizações criminosas será realizada independentemente da identificação civil.

${ }^{67}$ Art. $7^{\circ}$ Não será concedida liberdade provisória, com ou sem fiança, aos agentes que tenham tido intensa e efetiva participação na organização criminosa.

68 Art. 10 Os condenados por crime decorrentes de organização criminosa iniciarão o cumprimento da pena em regime fechado.

${ }^{69}$ Art. $5^{\circ}(\ldots)$

LVIII - o civilmente identificado não será submetido a identificação criminal, salvo nas hipóteses previstas em lei

${ }^{70}$ Art. $5^{\circ}(\ldots)$

II - ninguém será obrigado a fazer ou deixar de fazer alguma coisa senão em virtude de lei;

${ }^{71}$ Art. $7^{\circ}$ Não será concedida liberdade provisória, com ou sem fiança, aos agentes que tenham tido intensa e efetiva participação na organização criminosa.
} 
agente teve "intensa e efetiva participação"? O que se sabe é que ele terá sua liberdade usurpada, sem nem haver decisão que o considere culpado.

Vê-se, claramente, que há restrições de direitos e garantias individuais todas as vezes que uma norma faz menção à expressão organização criminosa. A prisão cautelar é medida de exceção, mas quando se trata de organização criminosa, a liberdade provisória é vedada por lei; não importa o crime supostamente cometido por este "ente abstrato", fato é que os seus integrantes sempre iniciarão o cumprimento de pena em regime fechado. Na verdade, neste caso, poderá o acusado, ainda sem transito em julgado, ser submetido ao regime disciplinar diferenciado, pois a Lei 7.210/1984 diz:

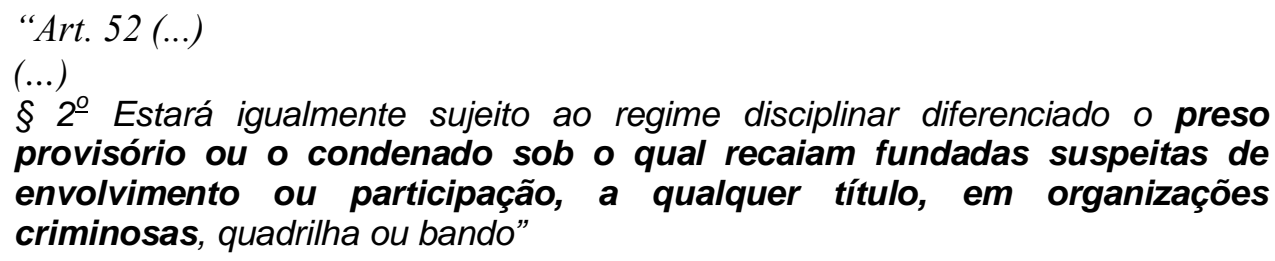

Ele não precisa cometer crime doloso, falta grave ou subverter a ordem ou disciplina interna do estabelecimento prisional, tais previsões são para os presos provenientes da criminalidade comum. O "inimigo", pelo simples fato de assim o ser considerado, está sujeito igualmente ao RDD.

Felizmente, por hora, os Habeas Corpus impetrados têm servido para conter tamanha ilegalidade, como se extrai do julgado colacionado abaixo:

"EMENTA

PROCESSUAL PENAL. HABEAS CORPUS. CRIMES PRATICADOS POR ORGANIZAÇÃO CRIMINOSA. SENTENÇA CONDENATÓRIA. INCLUSÃO DO CONDENADO NO REGIME DISCIPLINAR DIFERENCIADO. FALTA GRAVE NÃO COMPROVADA. AUSENNCIA DE REGISTRO QUE DESABONE A CONDUTA CARCERÁRIA DO PACIENTE. CONSTRANGIMENTO ILEGAL CARACTERIZADO. ORDEM CONCEDIDA. 1) Nos termos do artigo 52, parágrafo $2^{o}$, da Lei $n^{o} 7.210 / 84$, com a redação dada pela Lei $n^{\circ} 10.792$, de $1^{\circ}$ de dezembro de 2003, "Estará igualmente sujeito ao regime disciplinar diferenciado o preso provisório ou o condenado sob o qual recaiam fundadas suspeitas de envolvimento ou participação, a qualquer título, em organizações criminosas, quadrilha ou bando" (cf. art. cit.). 2) Contudo, as fundadas suspeitas de envolvimento do paciente em organização criminosa, que serviu como fundamento do ato judicial ora impugnado, tendo em vista sua condenação nos autos da Ação Penal $n^{o}$ 2003.36.00.015427-1, como incurso nas penas do artigo 22, parágrafo único, da Lei $n^{\circ}$ 7.492/86; do artigo 
$1^{o}$, inciso VI, parágrafo $4^{o}$, da Lei $n^{\circ}$ 9.613/98; e dos artigos 61, inciso II, letra 'b', 62, inciso II, e 69 do Código Penal, deve ter origem em atos praticados pelo detento (condenado ou internado) dentro do estabelecimento prisional, eis que o aludido Regime Disciplinar Diferenciado - RDD tem por única finalidade resguardar a ordem e a segurança do estabelecimento penal, embora, por óbvio, tenha reflexo direto na sociedade, contra a ação delituosa de presidiários. 3) $O$ fato de o detento, como na hipótese em exame, ter integrado organização criminosa, para praticar determinados delitos, que lhe renderam condenação, por si só, não autoriza sua inclusão do aludido regime diferenciado, que é pena por infração disciplinar carcerária. 4) No caso em análise, não há comprovação de ter o condenado praticado falta grave. Ao contrário, pois, segundo atestou o Diretor da Unidade Prisional Regional Pascoal Ramos, em Mato Grosso, o paciente, oriundo do Departamento de Polícia Federal, em 13 de maio de 2003, à época, com prisão temporária decretada em seu desfavor, não registra nenhuma nota que desabone sua conduta.

5) Assim sendo, sua inclusão no aludido regime disciplinar, atendendo solicitação desfundamentada do Superintendente do Sistema Prisional, da Secretaria de Justiça e Segurança Pública do Estado de Mato Grosso, caracteriza constrangimento ilegal. 6) Ordem concedida, para desconstituir a decisão que determinou a inclusão do paciente no Regime Disciplinar Diferenciado - RDD, por falta de amparo legal. $^{72 ”}$ (grifei)

Extrai-se, contudo, da leitura do item 2, que no momento de sua condenação, teve o paciente a pena majorada, por incidência do $\$ 4^{\circ}$ do artigo $1^{\circ}$ da Lei $9.613 / 1998^{73}$, pois foi considerado integrante de organização criminosa, a despeito das duras críticas feitas pela doutrina autorizada. A referida norma, que por versar sobre aplicação da pena, tem cunho material, somente poderia ser aplicada na primeira hipótese prevista ("se o crime for cometido de forma habitual"), sendo letra morta a hipótese que versa sobre organização criminosa enquanto perdurar essa situação de indefinição legal.

Ainda na análise da Lei 9.613/1998, os crimes cometidos pelas supostas organizações criminosas têm sido considerados, pelo Poder Judiciário, como eficazes a constituírem-se crime pré-existente do delito de

\footnotetext{
${ }^{72}$ TRF $1^{\circ}$ região, HC 2004.01.00.000468-5/MT. Rel. Juiz Plauto Ribeiro. Mato Grosso, 17 fev. 2004.

${ }^{73}$ Art. $1^{\circ}$ Ocultar ou dissimular a natureza, origem, localização, disposição, movimentação ou propriedade de bens, direitos ou valores provenientes, direta ou indiretamente, de crime: (...)

$\S 4^{\circ}$ A pena será aumentada de um a dois terços, nos casos previstos nos incisos I a VI do caput deste artigo, se o crime for cometido de forma habitual ou por intermédio de organização criminosa.
} 
lavagem de dinheiro, tipificado pelo artigo $1^{\mathrm{o}}$, aplicando-se o decreto legislativo 231/2003 e o decreto 5.015/2004, que aprovou e promulgou, respectivamente, a Convenção de Palermo $^{74}$, buscando-se o conceito perdido, sobre a qual teceremos comentários no tópico seguinte.

Observe que a violação do princípio da legalidade neste caso é ainda mais flagrante, vez que se utiliza da expressão "organização criminosa", para imputar ao acusado o crime de lavagem de capitais, crime este autônomo, mas vinculado à existência de um crime pré-existente, taxativamente disposto em lei. Trata-se aqui de utilizar uma expressão sem conteúdo definido para a imputação de um crime. Somente os crimes praticados em organização criminosa, conforme o inciso VII do $\operatorname{artigo} 1^{\circ}$ da Lei $9.613 / 1998^{75}$, ensejam a materialização do crime de lavagem de capitais, por conseguinte, não se pode fazer incidir o tipo penal sobre atividades provenientes de quadrilhas ou bandos ou associações criminosas, vez que se estaria interpretando extensivamente uma norma penal incriminadora.

Ora, se não se sabe o que é organização criminosa, logo, não se tem legalmente definida a conduta proibida. Forçosa é, portanto, o entendimento de que este inciso encontra-se vazio de eficácia, não servindo para compor o crime de lavagem de dinheiro.

Insta ressaltar que "a comissão do Conselho de Justiça Federal destinada a examinar e propor o aprimoramento da legislação de combate à lavagem de dinheiro (Portaria $n^{\circ} 98$, de 4/09/2002), composta por membros da Magistratura Federal, do Ministério Público Federal, do Departamento de Polícia Federal, do Banco Central, da Federação Brasileira de Bancos, da Secretaria da Receita Federal e do Conselho de Controle de Atividades Financeiras do Ministério da Fazenda (COAF), também propôs a definição

\footnotetext{
${ }^{74}$ Consultar o anexo A

${ }^{75}$ Art. $1^{\circ}$ Ocultar ou dissimular a natureza, origem, localização, disposição, movimentação ou propriedade de bens, direitos ou valores provenientes, direta ou indiretamente, de crime: (...) VII - praticado por organização criminosa.
} 
legal do conceito de organização criminosa para tornar plenamente eficaz o inciso VII, da Lei nº. 9.613/1998,76

Tal situação tende a mudar com o julgamento, no STF, do Habeas Corpus 96.007-SP $\mathrm{SP}^{77}$, impetrado no caso da Igreja Renascer, com o Ministro Marco Aurélio como relator. Em seus votos, tanto o Ministro Marco Aurélio quanto o Ministro Dias Tóffoli concluíram que inexistindo definição legal no Brasil de organização criminosa, esta não serve, por conseguinte, como fundamento para o crime de lavagem de capitais, que não dispensa a ocorrência de crime antecedente.

Já aquele que cede à "extorsão estatal" e decide, por estar arrependido ou não, fazer uso da delação premiada, prevista no artigo $6^{\circ}$ da Lei. 9.034/1995 ${ }^{78}$, e com sua colaboração espontânea leva ao esclarecimento de infrações penais, pode não ter o seu direito à redução da pena, simplesmente porque neste caso, dependendo de quem seja, e da reação da sociedade, pode o Ministério Público e o juiz decidir que aquilo não se configura organização criminosa, mas quadrilha, por exemplo. Aplicar-se-á o Direito Penal do Autor, abusando-se do poder para dar uma resposta à sociedade.

Imaginemos um traficante, integrante de uma grande organização de tráfico de drogas, que tem seu nome vinculado na mídia diariamente, sempre o ligando a crimes atrozes. Se um dia este se arrepender e contribuir com a polícia e o Ministério Público durante as investigações, alguém vislumbra a possibilidade lhe aplicarem o artigo em discussão? Dirão que não havia organização criminosa, mas associação criminosa, nos termos do artigo 35 da Lei 11.343/2006, e que o artigo em análise só se aplica naquela hipótese.

\footnotetext{
${ }^{76}$ SOUZA, Alexis Sales de Paula e. O conceito de organização criminosa no direito comparado e na legislação brasileira. Disponível em <http://www.ibccrim.org.br/site/artigos/_imprime.php?jur_id=9531>. Acesso em 26 ago. 2009. ${ }_{78}^{77}$ STF, HC 96.007-SP. Rel. Ministro Marco Aurélio.

${ }^{78}$ Art. $6^{\circ}$ Nos crimes praticados em organização criminosa, a pena será reduzida de um a dois terços, quando a colaboração espontânea do agente levar ao esclarecimento de infrações penais e sua autoria.
} 
Com relação à Lei 11.343/2006, há outra hipótese que muito se assemelha com o que foi falado acima, vejamos:

"Art. 33. Importar, exportar, remeter, preparar, produzir, fabricar, adquirir, vender, expor à venda, oferecer, ter em depósito, transportar, trazer consigo, guardar, prescrever, ministrar, entregar a consumo ou fornecer drogas, ainda que gratuitamente, sem autorização ou em desacordo com determinação legal ou regulamentar:

Pena - reclusão de 5 (cinco) a 15 (quinze) anos e pagamento de 500 (quinhentos) a 1.500 (mil e quinhentos) dias-multa.

(...)

$\S 4^{\circ}$ Nos delitos definidos no caput e no $\S 1^{\circ}$ deste artigo, as penas poderão ser reduzidas de um sexto a dois terços, vedada a conversão em penas restritivas de direitos, desde que o agente seja primário, de bons antecedentes, não se dedique às atividades criminosas nem integre organização criminosa. (grifei)

Novamente vê-se aberta as portas para a utilização do Direito Penal do Autor. Se a figura pública, isto é, se a difusão do seu nome for muito grande junto à sociedade, se a mídia o rotulou como o inimigo, basta que o juiz decida que o réu integra uma organização criminosa para que se negue a diminuição da pena prevista, independentemente de ser o agente primário e de ter bons antecedentes, dando-se uma falsa resposta a sociedade de que foi feito justiça.

Percebe-se agora, mediante tais exemplos, claramente os perigos que alertávamos, desde o início, de preencher esta lacuna da lei mediante interpretações subjetivas por parte dos magistrados e da doutrina. A lei, da forma que está, permite que se pratiquem atos abusivos e às margens dos princípios e regras do Direito Penal garantista que adotamos.

Concluindo, impossível utilizar-se do artigo $3^{\circ}$ do Código de Processo Penal $^{79}$, fazendo uso da interpretação extensiva ou aplicação analógica, na busca pelo conceito nas demais figuras previstas na Lei. 9.034/95, pois, como já afirmado no início deste capítulo, ainda que a maioria das normas em exame seja de natureza processual, todas elas dependem de um conceito de Direito material, bem como refletem diretamente na liberdade do acusado.

\footnotetext{
${ }^{79}$ Art. $3^{-}$A lei processual penal admitirá interpretação extensiva e aplicação analógica, bem como o suplemento dos princípios gerais de direito.
} 
Nesse sentido, o abalizado ensinamento do jurista Luiz Flávio Gomes:

"A Lei 9.034/95 tem cunho predominantemente processual. Enfocada como lei processual, não seria o caso de se admitir interpretação extensiva ou aplicação analógica (CPP, art. $\left.3^{\circ}\right)$, estendendo-se o conceito de quadrilha ou bando ou mesmo associação para as organizações criminosas?

A resposta é negativa. $O$ disposto no art. $3^{\circ}$ do CPP só é valido para as leis de conteúdo genuinamente processual. Onde o CPP fala em denúncia pode-se também ler queixa; onde fala de prazo para oferecimento da primeira pode-se estender para a segunda etc.

A lei processual deixa de ter caráter cristalinamente processual em duas hipóteses: (a) quando reflete diretamente no ius libertatis (lei que versa sobre o regime de cumprimento de pena, sobre fiança liberdade provisória sem fiança etc.); (b) quando sua eficácia é dependente de um conceito de Direito penal: é o que se passa justamente como todos os dispositivos legais da Lei 9.034/95 que fazem expressa referência às organizações criminosas. São leis processuais (em geral), mas ao se referirem explicitamente às organizações criminosas deixam de ter eficácia, por ora, por falta de um conteúdo normativo para esse conceito. ${ }^{80}$,

Por todo o exposto, tratando-se de normas que têm como escopo a restrição de direitos e garantias do indivíduo, sua aplicação somente será admitida quando houver lei que conceitue organização criminosa. $\mathrm{Na}$ atual situação, devem ser vedadas pelo ordenamento brasileiro por violarem o princípio da legalidade de suma importância contra as investidas arbitrárias e nefastas do Estado.

Corroborando nossa afirmação, buscamos, novamente, os ensinamentos do jurista Luiz Flávio Gomes sobre o tema:

\section{“6. Impossibilidade de restrição de direitos fundamentais}

Se não existe nenhuma definição legal válida, no direito interno brasileiro, do que se entende por organização criminosa, resulta evidente que nenhuma restrição (a qualquer direito fundamental) é cabivel com base nesta locução indefinida e vaga (que é uma alma em busca de um corpo). ${ }^{81 "}$ (grifos no original)

\footnotetext{
${ }^{80}$ GOMES, Luiz Flávio. Crime organizado: que se entende por isso depois da Lei n. 10.217, de 11.04.01? (Apontamentos sobre a perda de eficácia de grande parte da Lei 9.034/95). Disponível em <http://www.ibccrim.org.br/site/artigos/_imprime.php?jur_id=928>. Acesso em 26 ago. 2009.

81 Id., Que se entende por crime organizado (Parte 2). Disponível em: <http://www.lfg.com.br/public_html/article.php?story=20100301095141671>. Acesso em 26 mar. 2010.
} 


\section{4 - Da impossibilidade de se recorrer à Convenção das Nações Unidas Contra o Crime Organizado Transnacional}

A Convenção das Nações Unidas Contra o Crime Organizado Transnacional $^{82}$, adotada em Nova York, em 15 de novembro de 2000, aprovada pelo Decreto Legislativo 231/2003 e promulgada pelo decreto 5.015/2004 dispõe em seu artigo primeiro:

"Art. $1^{\circ}$

Objetivo

O objetivo da presente Convenção consiste em promover a cooperação para prevenir e combater mais eficazmente a criminalidade organizada transnacional." (grifei)

Já o artigo segundo da Convenção, observando a boa técnica legislativa, define o que se entende por grupo criminoso organizado.

"Art. $2^{\circ}$

Terminologia

Para efeitos da presente Convenção, entende-se por:

a) 'Grupo criminoso organizado' - grupo estruturado de três ou mais pessoas, existente há algum tempo e atuando concertadamente com o propósito de cometer uma ou mais infrações graves ou enunciados na presente Convenção, com a intenção de obter, direta ou indiretamente, um benefício econômico ou outro benefício material;

b) (...)

c) 'Grupo estruturado' - Grupo formado de maneira não fortuita para a prática imediata de uma infração, ainda que seus membros não tenham funções formalmente definidas, que não haja continuidade na sua composição e que não disponha de uma estrutura elaborada;"

Cristalino, portanto, o âmbito de incidência da Convenção, que somente pode ser aplicada nos casos de criminalidade organizada transnacional, conforme se endente pela leitura do artigo primeiro. Logo, o conceito trazido pelo artigo $2^{\circ}$ aplica-se, tão somente, a esta forma de criminalidade.

Fazer incidir este conceito sobre as organizações criminosas sem cunho transnacional significa fazer uso da analogia, instrumento utilizado para completar lacunas deixadas na lei, sendo, no entanto, vedada pelo Direito Penal pátrio quando maléfica ao acusado.

${ }^{82}$ Vide anexo A. 
Nas sempre claras lições de Luiz Flávio Gomes:

"A tese da admissão deste conceito de organização criminosa no direito interno brasileiro enfrenta dois obstáculos: (a) a Convenção versa (só) sobre a criminalidade organizada transnacional; admiti-la internamente para a criminalidade organizada não transnacional significaria autorizar (no Direito penal) a analogia in malam partem (que é vedada); (b) os tratados internacionais (centrípetos) não podem definir crimes e penas no Brasil (que exigem, por força da garantia da lex populi, uma lei discutida e aprovada pelo parlamento brasileiro). ${ }^{83}$,

Tratam-se, portanto, de coisa diversa que não devem ser confundidas, a exemplo da confusão conceitual entre organizações criminosas e quadrilha ou bando feita pelo legislador pátrio. A Convenção de Palermo versa sobre as organizações criminosas transnacionais, prescrevendo parâmetros para que cada Estado signatário promulgue leis tipificando as diversas condutas ali previstas.

Já as organizações criminosas sem cunho transnacional, cuja Lei 9.034/95 deveria tratar, permanecem carentes de definição legal. Nos ensinamentos de Luiz Flávio Gomes, “o Tratado de Palermo (que definiu o crime organizado transnacional), por exemplo, não possui valor normativo suficiente para delimitar internamente o conceito de organização criminosa (até hoje inexistente no nosso país). ${ }^{84,}$

Ademais, percebe-se a péssima definição dada às organizações criminosas, negando todos os caracteres necessários a definir uma verdadeira organização criminosa. O que se buscou foi uma definição muitíssimo mais vasta, possibilitando, com isto, abarcar toda forma de cumulação subjetiva estável para prática de crimes.

O próprio Fernando Capez, adepto de se aplicar analogicamente a Convenção às organizações criminosas internas, percebe problemas no conceito, em suas palavras: "o conceito é um pouco vago, pois a Convenção

83 GOMES, Luiz Flávio. Que se entende por crime organizado (Parte 2). $<$ http://www.lfg.com.br/public_html/article.php?story=20100301095141671>. Acesso em 26 mar. 2010.

${ }^{84}$ Ibid. 
exige que a organização esteja formada 'há algum tempo' sem definir com precisão quanto. ${ }^{85,}$

Concluindo, inadmissível é sua utilização pelos tribunais nacionais, o que infelizmente vem ocorrendo, para preencher a lacuna e conceituar organização criminosa, pois tal prática reveste-se de flagrante aplicação analógica in malan partem,. Em boa hora, contudo, com o julgamento, pelo STF, do HC 96.007-SP ${ }^{86}$, isto deve mudar.

Tratando do assunto com maestria, colacionamos novamente os ensinamentos de Luiz Flávio Gomes.

"Se a Convenção da ONU (Convenção de Palermo) diz respeito à criminalidade organizada transnacional, aplicá-la no direito interno para a criminalidade (uma espécie de criminalidade) que não reúne essa característica significa violar a garantia da lex stricta e admitir analogia contra o réu (analogia in malam partem). Em direito penal só vale (contra o réu) o que está na lei. Se o fato está expressamente previsto na lei pode o Estado adotar medidas restritivas (dos direitos fundamentais) contra o réu. Se o fato não está expressamente previsto na lei (lei formal, aprovada pelo parlamento) nada pode ser feito contra ele.

A Convenção da ONU estabeleceu uma determinada forma (jurídica). Essa forma jurídica só pode ter incidência em relação aos fatos rigorosamente adequados a ela. Uma criminalidade interna não tem nada a ver com criminalidade internacional ou transnacional. A divergência que existe entre a realidade (os fatos) e a forma jurídica criada (criminalidade transnacional) nos conduz a concluir que essa forma jurídica é inaplicável para fatos que não condizem com o seu conteúdo estrito.

(...)

Tendo em vista o que acaba de ser exposto, bem andaram os Ministros Marco Aurélio e Dias Tóffoli no Caso da Igreja Renascer (STF, HC 96.007-SP, rel. Min. Marco Aurélio, j. 10.11.2009): de acordo com seus votos não existe no Brasil definição legal do que se entende por organização criminosa. Logo, ela não serve (por ora) de base para o delito de lavagem de capitais (que está sendo imputado aos dirigentes da Igreja Renascer). ${ }^{87}$,"

\footnotetext{
${ }^{85}$ CAPEZ, Fernando. Curso de Direito Penal: Legislação Penal Especial, vol. 4. $4^{\mathrm{a}}$ ed. São Paulo: Saraiva, 2009. p. 248.

${ }^{86}$ STF, HC 96.007-SP. Rel. Ministro Marco Aurélio.

${ }^{87}$ GOMES, Luiz Flávio. Que se entende por crime organizado (Parte 3). Disponível em: $<$ http://www.lfg.com.br/public_html/article.php?story=20100301101842942〉. Acesso em 04 mar. 2010.
} 


\section{Capítulo 3}

\section{Das críticas ao Projeto de Lei do Senado 150/2006}

\section{1 - Do PLS 150/2006}

Apresentado pela Senadora Serys Slhessarenko, em 23 de maio de 2006, o Projeto de Lei do Senado, que se aprovado revogará a Lei 9.034/1995, tem como objetivo, nas palavras da senadora, a "difícil, mas necessária tarefa de definir, para efeitos penais, o conceito de 'crime organizado' (...) sem desrespeito às garantias do devido processo legal, tampouco às atribuições constitucionais dos órgãos envolvidos na persecução criminal. ${ }^{88,}$

Expurga-se, completamente, a presença de termos alheios ao conceito de crime organizado, tendo o texto original do artigo $1^{\circ}$ do PLS 150/2006 a seguinte redação:

"Art. $1^{o}$ Esta Lei define o crime organizado e dispõe sobre a investigação criminal, meios de obtenção de prova, crimes correlatos e procedimento criminal a ser aplicado."

A utilização errada do termo "crime organizado", quando correto é falar-se em "organizações criminosas" já foi por nós abordado em itens anteriores e sofrerá mudanças durante o seu trâmite, vindo a ser substituído.

Verifica-se, que o PLS pretende acabar de vez com a confusão presente desde o PLC 62, entre organização criminosa e quadrilha ou bando, que embora resolvido com a modificação do artigo $1^{\circ}$ Lei 9.034/1995 pela Lei 10.217/2001 ${ }^{89}$, diferenciando organização criminosa de quadrilha ou bando ou de associação criminosa manteve, no diploma legal referente à prevenção e repressão de ações praticadas por organizações criminosas, as duas figuras típicas.

\footnotetext{
${ }^{88}$ Diário do Senado Federal, p. 17.705, 24.05.2006.

${ }^{89}$ Art. $1^{\mathrm{o}}$ Esta Lei define e regula meios de prova e procedimentos investigatórios que versem sobre ilícitos decorrentes de ações praticadas por quadrilha ou bando ou organizações ou associações criminosas de qualquer tipo.
} 
Como não poderia deixar de ser, vez que vigora no país a ideia de que o Estado somente pode dar a resposta necessária mediante criações de tipos penais, tal fato também ocorre com o PLS em estudo, o qual busca na tipificação da conduta indesejada os meios para extingui-la. Falácia esta que é visível na prática, mas que ainda encontra-se presente nas mentes de quase todos os brasileiros, inclusive naqueles que têm a importante tarefa de editar leis, por influência do Direito Penal de Emergência, que exerce a importante função simbólica de que o Estado está atuante.

Assim sendo, o Projeto de Lei do Senado no 150/2006, originalmente apresentado, em seu artigo $2^{{ }^{900}}$, ao invés de limitar-se em conceituar uma

\footnotetext{
${ }^{90}$ Art. $2^{\circ}$ Promover, constituir, financiar, cooperar ou integrar, pessoalmente ou por interposta pessoa, associação, sob forma lícita ou não, de cinco ou mais pessoas, com estabilidade, estrutura organizacional hierárquica e divisão de tarefas para obter, direta ou indiretamente, com o emprego de violência, ameaça, fraude, tráfico de influência ou atos de corrupção, vantagem de qualquer natureza, praticando um ou mais dos seguintes crimes:

I - tráfico ilícito de substâncias entorpecentes ou que determinem dependência física ou psíquica (Lei $\mathrm{n}^{\circ} 6.368$, de 21 de outubro de 1976);

II - terrorismo;

III - contrabando ou tráfico ilícito de armas de fogo, acessórios, artefatos, munições, explosivos ou materiais destinados à sua produção (Lei no 9.437, de 20 de fevereiro de 1997);

IV - extorsão mediante seqüestro e suas formas qualificadas (art. 159 , caput e $\S \S 1^{\circ}, 2^{\circ}$ e $3^{\circ}$, do Decreto-Lei $\mathrm{n}^{\circ} 2.848$, de 7 de dezembro de 1940 - Código Penal);

V - contra a administração pública (arts. 312, caput e $\S 1^{\circ}, 313-\mathrm{A}, 313-\mathrm{B}, 314,315,316$, caput e $\S$ $2^{\circ}, 317,318,319,320,321,325,326,332$, 334, 335, 337, 337-A, 337-B, 337-C, 342, 344 e 347 do Decreto-Lei $\mathrm{n}^{\circ} 2.848$, de 7 de dezembro de 1940 - Código Penal);

VI - contra o sistema financeiro nacional (Lei ${ }^{\circ} 7.492$, de 16 de junho de 1986, salvo o parágrafo único do art. $4^{\circ}$ );

VII - contra a ordem tributária ou econômica (arts. $1^{\circ}$ a $6^{\circ}$ da Lei $n^{\circ} 8.137$, de 27 de dezembro de 1990);

VIII - contra as empresas de transporte de valores ou cargas e a receptação dolosa dos bens ou produtos auferidos por tais práticas criminosas;

IX - lenocínio e tráfico de mulheres (arts. 227 a 231 do Decreto- Lei no 2.848, de 7 de dezembro de 1940 - Código Penal);

$\mathrm{X}$ - tráfico internacional de criança ou adolescente (art. 239 da Lei $\mathrm{n}^{\circ}$ 8.069, de 13 de julho de 1990);

XI - lavagem de dinheiro, ocultação de bens, direitos e valores (Lei no 9.613, de 3 de março de 1998);

XII - tráfico ilícito de tecidos, órgãos ou partes do corpo humano (Lei n 9.434 , de 4 de fevereiro de 1997);

XIII - homicídio qualificado (art. 121, § 2º do Decreto-Lei n 2.848, de 7 de dezembro de 1940 Código Penal);

XIV - falsificação, adulteração ou alteração de produto destinado a fins terapêuticos ou medicinais (art. 273, caput e $\S \S 1^{\circ}, 1^{\circ}$-A e $1^{\circ}$-B, do Decreto-Lei n ${ }^{\circ} 2.848$, de 7 de dezembro de 1940 - Código Penal);

XV - contra o meio ambiente e o patrimônio cultural (Lei n ${ }^{\circ}$ 9.605, de 12 de fevereiro de 1998); XVI - outros crimes previstos em tratados ou convenções internacionais de que o Brasil seja parte. Pena - reclusão, de cinco a dez anos, e multa, sem prejuízo das penas correspondentes aos demais crimes cometidos.

$\S 1^{\circ}$ Nas mesmas penas incorre quem, por meio do crime organizado:
} 
organização criminosa, o que, por si só, possibilitaria a efetiva utilização dos meios de produção de prova e a repressão dos crimes perpetrados por seus agentes, preferiu tipificá-lo.

Nota-se que, diferentemente dos demais projetos de lei que versam sobre a matéria, o artigo $2^{\circ}$ do PLS 150/06 tem como condutas típicas a promoção, constituição, financiamento, cooperação e integração, e não a associação como núcleo do tipo penal. Na justificativa a Senadora aduz que "o fato criminoso a ser descrito não se resume à mera reunião, agregação, partilha ou divisão de alguma coisa, ou seja, na conduta de união, em si mesma, de certo número de pessoas, mas sim na ação precedente de promover, constituir, financiar, cooperar ou integrar essa associação ${ }^{91}$."

Pretendeu-se adotar o número mínimo de 5 integrantes para a sua configuração típica, tratando-se, portanto de um crime plurissubjetivo, consumando-se no momento em que houver a convergência de vontades, no

I - gere, direta ou indiretamente, ou controla, de qualquer modo, atividades econômicas ou serviços públicos com o fim de auferir proveito econômico;

II - frauda licitações, em qualquer de suas modalidades, ou concessões, permissões e autorizações administrativas;

III - intimida ou influencia, por qualquer dos modos de execução referidos no caput deste artigo, testemunhas ou funcionários públicos responsáveis pela apuração de atividades do crime organizado; impede ou dificulta, valendo-se dos mesmos modos, a investigação do crime organizado;

IV - financia campanhas políticas destinadas à eleição de candidatos com a finalidade de garantir ou facilitar as ações do crime organizado ou a impunidade de seus membros.

$\S 2^{\circ}$ Nas mesmas penas incorre, ainda, quem fornece, oculta ou tem em depósito armas, munições e instrumentos destinados ao crime organizado; quem lhe proporciona locais para reuniões ou, de qualquer modo, alicia novos membros.

$\S 3^{\circ} \mathrm{A}$ pena é aumentada de um terço até a metade:

I - se a estrutura do crime organizado for constituída por mais de vinte pessoas;

II - se, na atuação do crime organizado, houver emprego de arma de fogo, concurso de agente público responsável pela repressão criminal ou colaboração de criança ou adolescente;

III - se qualquer dos concorrentes for funcionário público, valendo-se o crime organizado dessa condição para a prática de infração penal;

IV - se o produto ou proveito da infração penal destinar-se, no todo ou em parte, ao exterior.

$\S 4^{\circ}$ A pena é aumentada de metade para quem exerce o comando, individual ou coletivo, do crime organizado, ainda que não pratique pessoalmente atos de execução.

$\S 5^{\circ}$ Se qualquer um dos concorrentes do crime organizado for funcionário público, o recebimento da denúncia quanto a ele, após a defesa preliminar no prazo de dez dias, poderá provocar o afastamento cautelar do exercício de suas funções, sem prejuízo de remuneração e dos demais direitos previstos em lei, até o julgamento final da ação penal.

$\S 6^{\circ}$ A condenação acarretará ao funcionário público a perda do cargo, função, emprego ou mandato eletivo, e a interdição para o exercício de função ou cargo público pelo dobro do prazo da pena aplicada.(Art. $2^{\circ}$ do PLS 150/2006)

${ }_{91}$ Diário do Senado Federal, p. 17.705, 24.05.2006. 
entanto, necessário é o preenchimento de outros requisitos, tais como estabilidade, estrutura organizacional hierárquica e divisão de tarefas.

Exigia-se ainda um especial fim de agir, que é voltarem-se suas condutas para "obter, direta ou indiretamente, com o emprego de violência, ameaça, fraude, tráfico de influência ou atos de corrupção, vantagem de qualquer natureza, praticando um ou mais dos seguintes crimes."

Os crimes previstos nos incisos mostravam-se taxativos, não configurando o crime, por conseguinte, quando o ilícito praticado for diverso daqueles ali elencados. Portanto, somente se consumaria o crime que se pretende tipificar quando presentes todos estes requisitos (cinco ou mais integrantes, estabilidade, estrutura organizacional hierárquica, divisão de tarefas com intuito de obter, direta ou indiretamente, com emprego de violência, ameaça, fraude, tráfico de influencia ou atos de corrupção, vantagem de qualquer natureza, praticando um ou mais dos crimes taxativamente previstos nos incisos seguintes). Faltando um destes elementos, atípica seria a conduta.

O texto original do PLS 150/06 previa como meios de obtenção de prova a colaboração premiada; interceptação de comunicação telefônica e a interceptação ambiental de sinais eletromagnéticos, óticos ou acústicos, nos termos da legislação específica; ação controlada; acesso a registros de ligações telefônicas, dados cadastrais, documentos e informações eleitorais, comerciais e de provedores da internet e quebra dos sigilos financeiro, bancário e fiscal, nos termos da legislação específica. Todos dependentes de autorização judicial, salvo a colaboração premiada.

Verifica-se, ainda, a intenção de se retirar, como meio de obtenção de provas, a infiltração do agente policial, pois, nas palavras da Senadora:

"A proposta não hesita, ainda, em suprimir o instituto da 'infiltração policial' do direito brasileiro (art. $2^{\circ}, V$, da Lei $n^{o}$ 9.034, de 3 de maio de 1995), porque viola o patamar ético-legal do Estado Democrático de Direito, sendo inconcebível que o EstadoAdministração, regido que é pelos princípios da legalidade e da moralidade (art. 37, caput, da CF), admita e 
determine que seus membros (agentes policiais) pratiquem, como co-autores ou partícipes, atos criminosos, sob o pretexto da formação da prova. Se assim fosse, estaríamos admitindo que o próprio Estado colaborasse, por um momento que seja, com a organização criminosa na execução de suas tarefas, o que inclui até mesmo a prática de crimes hediondos. Muito melhor será que o Estado-Administração, localizando uma organização criminosa, ao invés de infiltrar nela seus agentes, debele essa organização, seja de forma imediata ou retardada (através de ação controlada).

Não bastassem as razões constitucionais, éticas, legais e lógicas já destacadas, ainda é possivel opor outros argumentos de ordem prática contra a 'infiltração de agentes'. A situação mais grave será o desrespeito a qualquer limite jurisdicional imposto à atuação dos agentes infiltrados. Imagine-se, por exemplo, quando o agente infiltrado estiver na presença de criminosos e lhe for ordenada a prática de um crime (v. g., o homicídio de um traficante preso pela organização rival). Nessa situação, o agente não terá como escolher entre cometer e não cometer o crime (limite imposto judicialmente), pois, se não obedecer aos integrantes da organização, poderá simplesmente ser executado. É isso que o Estado pretende de seus agentes? É isso que podemos esperar de um Estado Democrático de Direito? É isso que podemos denominar por 'moralidade pública'?

Resta destacar que os mais experientes policiais já são conhecidos dos criminosos, logo, as pessoas escolhidas para essa difícil missão, de escolher entre a própria 'ida' ou o desrespeito aos limites judiciais definidos para a sua atuação, serão policiais recém ingressos na carreira, sem qualquer experiência e ainda com bases ético-profissionais não solidificadas, o que, não resta dúvida, poderá propiciar o surgimento de 'agentes duplos ${ }^{92}$."

Por fim, as regras de procedimento dos meios de obtenção de prova acima descritos vinham disciplinados nos artigos $4^{\circ}$ ao 11 . Já os artigos 12 a 16 previam novos tipos penais, ocorridos durante a investigação criminal e a obtenção de prova. Nos artigos 17 a 25 disciplinavam-se as regras do procedimento criminal e, finalmente, os artigos 26 a 31 traziam as disposições finais.

Com sua passagem pela Comissão de Constituição e Justiça, cuja relatoria ficou a cargo do Senador Aloizio Mercadante, o texto do Projeto de Lei do Senado sofreu significativas alterações.

A redação dada ao artigo $1^{\circ}$ retirou o termo crime organizado e o substituiu por organização criminosa, seguindo a melhor técnica, e recebeu dois parágrafos, vejamos:

"Art. $1^{o}$ Esta Lei define organização criminosa e dispõe sobre a investigação criminal, meios de obtenção de prova, crimes correlatos e procedimento criminal a ser aplicado.

$\$ 1^{\circ}$ Considera-se organização criminosa a associação, de três ou mais pessoas, estruturalmente ordenada e caracterizada pela divisão de tarefas, ainda que informalmente, com objetivo de obter, direta ou indiretamente, vantagem de

\footnotetext{
${ }^{92}$ Diário do Senado Federal, p. 17.706-17.707, 24.05.2006.
} 
qualquer natureza, mediante a prática de crimes cuja pena máxima seja igual ou superior a quatro anos ou que sejam de caráter transnacional.

$\$ 2^{\circ}$ Esta Lei se aplica também aos crimes previstos em tratado ou convenção internacional quando, iniciada a execução no País, o resultado tenha ou devesse ter ocorrido no estrangeiro, ou reciprocamente."

Nitidamente buscou-se adaptar o PLS 150/2006 à Convenção das Nações Unidas Contra o Crime Organizado Transnacional ao se reduzir o número de integrantes de 5 para 3, bem como prever a sua aplicação nos crimes previstos em tratado ou convenção internacional (leia-se Convenção de Palermo), nos termos do parágrafo $2^{\circ}$.

Pecou gravemente ao retirar do conceito a necessidade de uma estrutura organizacional hierárquica. O termo estrutura ordenada é por demais amplo, e não reflete a real natureza das organizações criminosas.

Já o artigo $2^{\circ}$ teve sérias e desastrosas modificações. Como já deixamos transparecer, nos posicionamos contrários à tipificação, contudo, inegavelmente o texto original do referido artigo mostrava-se mais condizente com os princípios do nosso ordenamento jurídico.

Retirou-se o rol de infrações penais, sob o argumento de que o enfoque deve ser dado ao ato de constituir organização criminosa, sendo esta a conduta proibida por violar os bens jurídicos "paz pública e ordem pública", adotando-se a pena máxima igual ou superior a quatro anos como critério objetivo da constituição do crime. Reduziu-se, ainda, a pena mínima em abstrato, de cinco para três anos, consagrando a técnica da sistematicidade, tendo como parâmetro o crime de associação para o tráfico, tipificado no artigo 35 da Lei. 11.343/2006 ${ }^{93}$. Suprimiu, em boa hora, a causa de aumento de pena tendo como fundamento o número de pessoas integrantes da organização, pois como bem observado, em nada muda a sua periculosidade.

\footnotetext{
${ }^{93}$ Art. 35. Associarem-se duas ou mais pessoas para o fim de praticar, reiteradamente ou não, qualquer dos crimes previstos nos arts. 33, caput e $\S 1^{\circ}$, e 34 desta Lei:

Pena - reclusão, de 3 (três) a 10 (dez) anos, e pagamento de 700 (setecentos) a 1.200 (mil e duzentos) dias-multa.

Parágrafo único. Nas mesmas penas do caput deste artigo incorre quem se associa para a prática reiterada do crime definido no art. 36 desta Lei. (Art. 35 da lei. 11.343/2006)
} 
Desse modo, assim ficou o texto do artigo $2^{\circ}$, aprovado pelo Senado:

"Art. $2^{o}$ Promover, constituir, financiar, cooperar, integrar, favorecer, pessoalmente ou por interposta pessoa, organização criminosa.

Pena: reclusão, de três a dez anos, e multa, sem prejuízo das penas correspondentes aos demais crimes praticados.

$\S 1^{\circ}$ Nas mesmas penas incorre quem:

I - por meio de organização criminosa:

a) frauda concursos públicos, licitações, em qualquer de suas modalidades, ou concessões, permissões e autorizações administrativas;

b) intimida ou influencia testemunhas ou funcionários públicos incumbidos da apuração de atividades de organização criminosa;

c) impede ou, de qualquer forma, embaraça a investigação de crime que envolva organização criminosa;

II - financia campanhas políticas destinadas à eleição de candidatos com a finalidade de garantir ou facilitar as ações de organizações criminosas.

$\S 2^{\circ}$ Nas mesmas penas incorre, ainda, quem fornece, oculta ou tem em depósito armas, munições e instrumentos destinados ao crime organizado; quem lhe proporciona locais para reuniões ou, de qualquer modo, alicia novos membros.

$\S 3^{\circ}$. Aplicam-se em dobro as penas, se na atuação da organização criminosa houver emprego de arma de fogo.

$\$ 4^{\circ}$ A pena é agravada para quem exerce o comando, individual ou coletivo, da organização criminosa, ainda que não pratique pessoalmente atos de execução.

$\$ 5^{\circ}$ A pena é aumentada de um sexto a dois terços:

I - se há colaboração de criança ou adolescente;

II - se há concurso de funcionário público, valendo-se a organização criminosa dessa condição para a prática de infração penal;

III - se o produto ou proveito da infração penal destinar-se, no todo ou em parte, ao exterior;

IV - se a organização criminosa mantém conexão com outras organizações criminosas independentes;

$V$ - se as circunstâncias do fato evidenciarem a transnacionalidade da organização.

$\S 6^{\circ}$ Se qualquer um dos integrantes da organização criminosa for funcionário público, poderá o juiz determinar seu afastamento cautelar do exercício de suas funções ou mandato eletivo, para garantia do processo, sem remuneração, não sem antes ouvir, no prazo máximo de 15 (quinze) dias, testemunhas indicadas pela acusação e defesa, podendo a suspensão, que será decidida nas 24 (vinte e quatro) horas seguintes à audiência, perdurar até a decisão final do processo, devendo o funcionário retomar suas funções, se absolvido, e ficando a Administração Pública obrigada a pagar-lhe a remuneração a que teria direito no período da suspensão.

$\S 7^{\circ}$ Havendo indícios de participação de policial nos crimes de que trata esta Lei, a Corregedoria de Polícia instaurará imediatamente inquérito policial, comunicando ao Ministério Público, que designará membro para acompanhar o feito obrigatoriamente até a sua conclusão.

$\S 8^{\circ}$ A condenação acarretará ao funcionário público a perda do cargo, função, emprego ou mandato eletivo, e a interdição para o exercício de função ou cargo público pelo dobro do prazo da pena aplicada."

Além das mudanças acerca do conceito de organização criminosa e seu tipo penal, o texto final aprovado inseriu a previsão de se utilizar, como 
meio de obtenção de prova, a infiltração do agente policial, com uma seção disciplinando as regras de sua aplicação, e realizou modificações nas regras de "colaboração premiada", sugeridas pelo Ministro Gilmar Mendes. Outro fator relevante foi a discussão acerca da possibilidade do Ministério Público realizar investigações.

Verifica-se, portanto, que o texto final aprovado e encaminhado para a Câmara, no dia 09 de dezembro de 2009, onde aguarda votação, ao tipificar o crime de organização criminosa, pretende inserir um novo tipo de perigo abstrato em nosso ordenamento, sobre o qual teceremos críticas a seguir.

\section{2 - O problema da dupla inconstitucionalidade do tipo penal de organização criminosa que se pretende criar}

A tipificação do crime de organização criminosa encontra óbice intransponível em dois pontos fundamentais, que são a inconstitucionalidade de se criar o tipo penal de organização criminosa por ausência de bem jurídico claro e determinado a ser tutelado e pela proibição da criação de crimes que violem o axioma nullum crimen sine injuria, o que nos conduz a negá-la diante desta dupla inconstitucionalidade. Tais impedimentos serão, nas linhas que se seguem, abordados.

O Direito penal, pelo princípio da subsidiariedade e da intervenção mínima, somente se encontra autorizado a agir quando há ofensa ou ameaça (concreta) de ofensa a um bem jurídico relevante e impossível de ser resguardado por outro ramo do Direito.

Os bens jurídicos, por sua vez, consistem em valores fundamentais emanados pela Constituição e desempenham importante função limitadora da atividade legislativa, impedindo a criminalização indiscriminada de condutas. Este papel do bem jurídico é conhecido como "função políticocriminal do bem jurídico”. Não é, contudo, qualquer valor consagrado pela 
CF que enseja o surgimento de um bem jurídico tutelável pelo Direito penal, mas sim aqueles que exprimem valores fundamentais.

Buscamos os ensinamentos de Luís Greco para corroborar o que se esta a afirmar:

"O conceito político-criminal de bem jurídico é possível. Ele tem de estar arrimado na Constituição, mas não se limita a meramente refletir os valores que a Constituição consagra, uma vez que somente valores fundamentais podem justificar a gravidade da intervenção penal (princípio da subsidiariedade) (.... $)^{94,}$

O bem jurídico supostamente tutelado pelo delito que se pretende tipificar é a paz pública, recebendo duras críticas de Antônio Sérgio A. de Moraes Pitombo que afirma que "na Lei Maior, inexiste disposição que identifique, em termos claros, paz pública como bem jurídico ${ }^{95 \%}$. Ao explicar, aduz com muita clareza que:

Vale notar que ora se adota paz pública como fim ultimo do convívio social, ora a reduzem à tranquiilidade do público, conforme se fez no Código Criminal do Império. Na primeira acepção, a magnitude da concepção implica considerar paz pública como objetivo primordial da tutela penal, pois o ordenamento jurídico como um todo se destina à pacificação social. Isso acarreta perda de orientação, porque a proteção jurídica de valores depende de objeto certo, sob pena de se aceitarem justificativas autoritárias, representadas por expressões de efeito, todavia, carentes de fundamentação.

Na inteligência da paz pública como ausência de perturbação das pessoas, nem se pode considerá-la como valor fundante de incriminação, razão pela qual a eventual violação não passa de ilícito administrativo, quando muito, contravenção penal (art. 39 a 42 da Lei 3.688/41)

A carência de raiz constitucional traz dois empecilhos graves à tipificação. Primeiro, a ausência de referência constitucional é obstáculo instransponível para o legislador penal, porque não se admite pôr em jogo o valor liberdade graças à salvaguarda de bem que não pertença à sua mesma orbita de importância normativa. Segundo, tal insuficiência retira da tipicidade a possibilidade de aferição quanto à lesão ao bem jurídico, com altos riscos de aplicação arbitrária do tipo legal, mediante simples subsunção ${ }^{96}$." (grifei)

Extrai-se, portanto, das claríssimas lições acima colacionadas, que o tipo penal que se pretende construir não apresenta um bem jurídico claro e determinado, que legitimaria a incidência da face mais violenta do Direito,

\footnotetext{
${ }^{94}$ GRECO, Luís. "Principio da ofensividade" e crimes de perigo abstrato - uma introdução ao debate sobre o bem jurídico e as estruturas do delito. In Revista Brasileira de Ciências Criminais. vol. 49, 2004. p. 89.

${ }^{95}$ PITOMBO, Antonio Sergio Altieri de Moraes. Organizações criminosas: nova perspectiva do tipo legal. São Paulo: Revista dos Tribunais, 2009. p. 169.

${ }^{96}$ Ibid.
} 
pois paz pública é função de todo o ordenamento jurídico, que tem como único fim a pacificação social; o Direito existe para positivar regras de convivência social, buscando, desta maneira, a paz pública.

Não se esta a negar que um crime abala de forma muito mais gravosa a paz social do que, por exemplo, uma disputa de vizinhos que verse sobre um direito de vizinhança, mas certo é também que, sejam as normas penais que incidirão sobre o fato criminoso, sejam as normas cíveis que incidirão sobre a discórdia entre vizinhos, ambas têm como função buscar a pacificação social. Paz pública é, portanto, objetivo de toda e qualquer norma; é a finalidade do Direito entendido em sua completude.

Em suma, pelo principio da subsidiariedade, da fragmentariedade e da intervenção mínima, não se pode conceber paz pública como um bem jurídico diante de seu conteúdo indeterminado, que por ser função primordial do Direito, acarreta em abarcar tudo. Assim sendo, concordamos com Antonio Sérgio A. de Moraes Pitombo no sentido de inexistir na Constituição a sua previsão de forma que possa se considerar um bem jurídico. Não havendo, portanto, previsão constitucional clara e vista a questão pela ótica da função político-criminal do bem jurídico, não há outro entendimento possível senão o de considerar inconstitucional a atividade legislativa que busca criminalizar tal conduta.

Mesmo aqueles que entendem que paz pública é sim um bem jurídico com sede constitucional, e por isso, a atividade legislativa que pretende criar um tipo penal para as organizações criminosas encontra arrimo da Constituição Federal, não podem fechar os olhos para o axioma garantista de nullum crimen sine injuria.

Dessa forma, o segundo obstáculo à tipificação decorre do atentado contra o princípio da ofensividade, de fundamental importância dentro de um Direito penal de garantias, introduzido pela nova ordem constitucional, que "retrata um dos instrumentos mais essenciais para a demarcação do 
âmbito do que é legitimamente punível"97, mas que parece ignorado pelos nossos legisladores e operadores do Direito.

Este "esquecimento" é resultante de uma das características mais marcantes da expansão do Direito penal e, logicamente, da anterior esquizofrenia, compartilhada por quase todos, no sentido de se crer que somente ele é capaz de por fim às situações indesejáveis.

"Em que pese sua natureza de condictio sine qua non da coerência e legitimação 'de todo o paradigma penal pós iluminista', a verdade é que o princípio da ofensividade não mereceu, até agora, a devida atenção do legislador e, muitas vezes, tampouco do juiz ou mesmo da ciência do Direito Penal. O caminho para alcançar seu pleno reconhecimento tanto no plano político-criminal como na praxis certamente não esta livre de complicações, mas parece digno de ser percorrido. ${ }^{98,}$

Busca-se a antecipação punitiva, isto é, busca-se a responsabilização criminal anterior à prática da conduta que se quer proibir, independentemente de se estar, neste primeiro momento, lesionando ou ameaçando concretamente um bem jurídico, carecendo, pois, o ius puniendi de legitimação.

"Contudo, a resposta do Estado tem sido a da concepção de um Direito Penal cada vez mais punitivo, preventivo e hipertrofiado. Um destes efeitos traduz-se na abundante utilização de tipos penais de perigo abstrato, em contraposição aos de lesão e perigo concreto, paradigmas do Direito Penal Clássico.

Essa técnica legislativa e político-criminal das últimas décadas, mormente das duas últimas, quando a sociedade global tomou consciência dos riscos e ameaças que caracterizam o processo de evolução da tecnologia, suscita não só conflitos com princípios fundamentais da ciência penal, senão também sérios e graves problemas de legitimação do ius puniendi, de sua fundamentação e de seus limites, já que a criminalização com uso do modelo dos tipos de perigo abstrato trata-se de flagrante antecipação da punição criminal. ${ }^{99}$ ",

Corroborando as afirmações acima temos os ensinamentos de Alice Bianchini, Antonio García-Pablos Molina e Luiz Flávio Gomes nos seguintes termos:

\footnotetext{
${ }^{97}$ BIANCHINI, Alice; MOLINA, Antonio García-Pablos de; GOMES, Luiz Flávio. Direito Penal: Introdução e princípios fundamentais. $2^{\mathrm{a} e d . ~ r e v . ~ a t u a l . ~ e ~ a m p l . ~ C o l e c ̧ a ̃ o ~ c i e ̂ n c i a s ~ c r i m i n a i s . ~ v o l 1 ~}$ (Coord.) GOMES, Luiz Flávio; CUNHA, Rogério Sanches. São Paulo: Revista dos Tribunais, 2009. p. 313.

${ }^{98}$ Ibid. p. 316.

99 ROMERO, Diogo. Reflexões sobre os crimes de perigo abstrato. Disponível em <http://jus2.uol.com.br/doutrina/texto.asp?id=5722>. Acesso em 22 mai. 2010.
} 
"A concepção do delito como uma conduta necessariamente ofensiva baseia-se, ademais, também na preocupação de determinar os limites racionais dentro dos quais pode o legislador legitimamente antecipar a tutela penal, que por natureza deve ser concebida como fragmentária e subsidiária.

(...)

$O$ adiantamento exagerado da intervenção punitiva em relação ao que tradicionalmente se considera o 'núcleo' do Direito penal não somente suscita conflitos com clássicos princípios (intervenção mínima, ofensividade, culpabilidade etc.), senão, principalmente, graves problemas de legitimação. $\mathrm{Na}$ doutrina alemã foi cunhada a expressão Vorfeldkriminalisierung (criminalização no âmbito prévio) para referir-se a esse fenômeno. ${ }^{100 "}$

O principio da ofensividade, ou da lesividade como alguns autores o denominam, assim como todos os demais, funciona como standard jurídico que vincula a atividade legislativa, impedindo que se editem normas que com ele não sejam compatíveis.

Ora, o que se busca no nosso ordenamento são mecanismos eficazes de investigação e produção de provas dos crimes cometidos em organização criminosa. Para tanto, basta ler o artigo $1^{\circ}$ da Lei $9.034 / 1995^{101}$ e o mesmo artigo constante no texto final do PLS $150 / 06^{102}$ aprovado pelo Senado Federal. A criação de um tipo penal para as organizações criminosas é, portanto dispensável ao consectário da lei, é não apenas fruto do atual movimento de expansão do Direito penal, mas também influência, no cenário internacional, de Estados estrangeiros, cuja legislação, e mais importante, os princípios diferem-se dos nossos.

Quando o próprio PLS 150/06, no $\$ 1^{\circ}$ do artigo $1^{\circ 103}$, dá o conceito de organização criminosa como aquela que tem como "objetivo de obter,

\footnotetext{
${ }^{100}$ BIANCHINI, Alice; MOLINA, Antonio García-Pablos de; GOMES, Luiz Flávio. Direito Penal: Introdução e princípios fundamentais. $2^{\mathrm{a} e d . ~ r e v . ~ a t u a l . ~ e ~ a m p l . ~ C o l e c ̧ a ̃ o ~ c i e ̂ n c i a s ~ c r i m i n a i s . ~}$ vol1 (Coord.) GOMES, Luiz Flávio; CUNHA, Rogério Sanches. São Paulo: Revista dos Tribunais, 2009. p. 312.

101 "Art. $1^{\circ}$ Esta Lei define e regula meios de prova e procedimentos investigatórios que versem sobre ilícitos decorrentes de ações praticadas por quadrilha ou bando ou organizações ou associações criminosas de qualquer tipo." (art. $1^{\circ}$ da Lei 9.034/1995)

102 "Art. $1^{\circ}$ Esta Lei define organização criminosa e dispõe sobre a investigação criminal, meios de obtenção de prova, crimes correlatos e procedimento criminal a ser aplicado". (art. $1^{\circ}$ do PLS $150 / 2006)$

103 “Art. $1^{\circ}(\ldots)$

$\S 1^{\circ}$ Considera-se organização criminosa a associação, de três ou mais pessoas, estruturalmente ordenada e caracterizada pela divisão de tarefas, ainda que informalmente, com objetivo de obter, direta ou indiretamente, vantagem de qualquer natureza, mediante a prática de crimes cuja pena
} 
direta ou indiretamente, vantagem de qualquer natureza, mediante a prática de crimes cuja pena máxima seja igual ou superior a quatro anos ou que sejam de caráter transnacional", vê-se claramente que a ação de promover, financiar, cooperar, integrar e favorecer organização criminosa são atos meramente preparatórios, incapazes de ferirem qualquer bem jurídico; a paz pública (para aqueles que entendem ser bem jurídico tutelável) somente será lesionada quando esta organização criminosa agir. Trata-se de tentativa (errônea) de erradicar os crimes que podem ou não virem a ser cometidos em organização criminosa tipificando os atos preparatórios.

Nas esclarecedoras lições sobre o tema:

"Com a lógica do Direito penal da ofensividade entra em contradição ou conflito frontal a acepção do delito como violação de um dever ou infração de mera desobediência, bem como algumas formas (ilegítimas) de antecipação da tutela penal (punição de determinados atos preparatórios, do perigo abstrato etc.)",104

Diego Romero, seguindo a mesma linha de pensamento acima descrita afirma que:

"Vislumbra-se, então, que tentando dar uma solução para esta crise da sociedade, o Direito Criminal é chamado "em primeira mão", e levado a trabalhar cada vez mais com os crimes de perigo abstrato, que abrangem no muito das vezes situações prévias ao crime (punem o pré-delito). No entanto, este alargamento do uso de tipos preventivos constitui-se em notória contradição aos princípios do Direito Penal Liberal que primam sempre pela punição do resultado efetivamente lesivo ao bem jurídico tutelado. "105

Insta ressaltar que o Direito penal clássico e de garantias considera os atos preparatórios desprezíveis ${ }^{106}$; não se pune os atos de mera

máxima seja igual ou superior a quatro anos ou que sejam de caráter transnacional. (art. $1^{\circ}, \S 1^{\circ}$ do PLS 150/2006)

${ }^{104}$ BIANCHINI, Alice; MOLINA, Antonio García-Pablos de; GOMES, Luiz Flávio. Direito Penal: Introdução e princípios fundamentais. $2^{\mathrm{a} e d . ~ r e v . ~ a t u a l . ~ e ~ a m p l . ~ C o l e c ̧ a ̃ o ~ c i e ̂ n c i a s ~ c r i m i n a i s . ~}$ vol1 (Coord.) GOMES, Luiz Flávio; CUNHA, Rogério Sanches. São Paulo: Revista dos Tribunais, 2009. p. 308.

105 ROMERO, Diogo. Reflexões sobre os crimes de perigo abstrato. Disponível em <http://jus2.uol.com.br/doutrina/texto.asp?id=5722>. Acesso em 22 mai. 2010.

${ }^{106}$ Os atos preparatórios somente serão relevantes para o Direito penal quando eles, por si só, constituírem crimes. A título de exemplo, podemos citar a compra de uma arma de fogo por que não tem autorização de porte de armas, com intuito de cometer um homicídio. Embora seja ato preparatório para o crime de homicídio, ainda que este não ocorra, responderá o agente pelo crime de porte ilegal de arma de fogo, previsto pelo artigo 14 da Lei. 10.826/2003. (Art. 14. Portar, deter, adquirir, fornecer, receber, ter em depósito, transportar, ceder, ainda que gratuitamente, emprestar, 
preparação para o cometimento do crime. Aquele que, a título de ilustração, com intuito de cometer um homicídio por envenenamento, compra uma substancia química destinada ao controle de pragas, que sabe ser altamente tóxica ao organismo humano, não pode ser punido neste momento, visto tratar-se de ato preparatório, indiferente para o Direito penal.

Ademais, frente ao princípio da ofensividade, não basta a subsunção meramente formal da conduta humana à conduta descrita no tipo penal, não basta a "adequação gramatical da conduta à letra da lei"107. Exige-se que se vá além e haja a verificação da tipicidade material, isto é, a verificação da ofensa ao bem jurídico tutelado.

As ações acima descritas não requerem um resultado real ou concreto de lesão ou ameaça de lesão, sendo desnecessária a exposição do bem jurídico a qualquer perigo concreto, pois se presume iure et iure que a conduta descrita é, pura e simplesmente, perigosa; não se preocupa com o resultado, mas sim com a adequação formal à letra fria da lei.

Importantes são as lições que colacionamos a baixo:

"Vislumbra-se que os crimes de perigo abstrato não buscam responder a determinado dano ou prejuízo social realizado pela conduta, senão evitá-la, barrá-la, prevenindo e protegendo o bem jurídico de lesão antes mesmo de sua exposição a perigo real, concreto, efetivo de dano. Ao fazer uso desta modalidade delitiva, quer o Direito Penal da atualidade proporcionar, ou melhor, dar a sensação de segurança ao corpo social. ${ }^{108}$ " (grifei)

Trazendo outro importante argumento contra os crimes de perigo abstrato, Diego Romero aduz que:

"ocorre que ao fazer isto o legislador opera uma inversão da carga probatória no processo penal, pois abdicando do dano e do nexo de causalidade a situação delitiva fica muito mais fácil de ser provada. No caso concreto não é necessário

remeter, empregar, manter sob guarda ou ocultar arma de fogo, acessório ou munição, de uso permitido, sem autorização e em desacordo com determinação legal ou regulamentar:

Pena - reclusão, de dois a quatro anos, e multa.

${ }^{107}$ BIANCHINI, Alice; MOLINA, Antonio García-Pablos de; GOMES, Luiz Flávio. Direito Penal: Introdução e princípios fundamentais. $2^{\mathrm{a} e d . ~ r e v . ~ a t u a l . ~ e ~ a m p l . ~ C o l e c ̧ a ̃ o ~ c i e ̂ n c i a s ~ c r i m i n a i s . ~}$ vol1 (Coord.) GOMES, Luiz Flávio; CUNHA, Rogério Sanches. São Paulo: Revista dos Tribunais, 2009. p. 311.

${ }_{108}$ ROMERO, Diogo. Reflexões sobre os crimes de perigo abstrato. Disponível em <http://jus2.uol.com.br/doutrina/texto.asp?id=5722>. Acesso em 22 mai. 2010. 
provar qualquer situação concreta, apenas a pura violação da norma jurídica, o que, com certeza, proporciona ao acusado poucas possibilidades de defesa ${ }^{109,}$

Forçoso é, portanto, concluir que "em virtude do princípio da ofensividade está proibido no Direito penal o perigo abstrato ${ }^{110}$,, em outras palavras, quando a conduta que se pretende criminalizar for incapaz de, por si só, lesionar ou ameaçar concretamente um bem jurídico claro e determinado, impossível é, diante do princípio da ofensividade, a sua tipificação.

Concluindo, a criação do tipo penal de organização criminosa, como pretende o PLS 150/2006, mostra-se duplamente inconstitucional. Assim o é, primeiramente, por não tutelar um bem jurídico claro e definido em sede constitucional, conforme os ensinamentos de Antonio Sergio A. de Moraes Pitombo acima expostos. Contudo, mesmo para aqueles que advogam ser a paz pública um bem jurídico tutelável pelo Direito penal, fechando os olhos para o fato de ser, na verdade, função primordial de todo o ordenamento jurídico, a tipificação encontra obstáculo no princípio da ofensividade, "princípio que encontra ressonância constitucional e legal, isto é, encontra eco tanto nos modernos modelos de Estado, que se caracterizam por ser constitucionais e democráticos de direito, como nos códigos e leis penais ${ }^{111}$."

\footnotetext{
109 ROMERO, Diogo. Reflexões sobre os crimes de perigo abstrato. Disponível em <http://jus2.uol.com.br/doutrina/texto.asp?id=5722>. Acesso em 22 mai. 2010.

110 BIANCHINI, Alice; MOLINA, Antonio García-Pablos de; GOMES, Luiz Flávio. Direito Penal: Introdução e princípios fundamentais. $2^{\mathrm{a} e d . ~ r e v . ~ a t u a l . ~ e ~ a m p l . ~ C o l e c ̧ a ̃ o ~ c i e ̂ n c i a s ~ c r i m i n a i s . ~}$ vol1 (Coord.) GOMES, Luiz Flávio; CUNHA, Rogério Sanches. São Paulo: Revista dos Tribunais, 2009. p 313-314.

${ }^{111}$ Ibid. p 314.
} 


\section{Capítulo 4}

\section{Conclusão}

Como se tentou demonstrar neste trabalho, vivemos um perigoso período de expansão do Direito penal, decorrente da veiculação, pelas mídias, do discurso do medo. Abre-se, desta forma, espaço para uma atuação legislativa desenfreada, com edições de leis incondizentes com o Direito penal clássico de garantias, ineficazes aos fins que se pretende alcançar, servindo apenas para hipertrofiar nosso já confuso sistema penal e, principalmente, exercer uma função simbólica de que o Estado está atuante e preocupado com as mazelas que atingem seus cidadãos.

Com a Lei 9.034/1995 não foi diferente. Sob o pretexto de se combater as organizações criminosas, eleitas, em nosso país, como o grande mal a ser enfrentado, buscaram-se novos mecanismos de investigação e redução das garantias processuais do acusado, vendo-as como obstáculo ao devido exercício do ius puniendi.

O texto final, depois de um tormentoso processo legislativo, mostrou-se infeliz ao retirar o conceito de organização criminosa, como pretendia o texto original apresentado, e, em seu lugar, dispor que a lei definiria e regularia os meios de prova e procedimentos investigatórios que versassem sobre crime resultante de ações de quadrilha ou bando, nas palavras de Antonio Scarance Fernandes, que participou do grupo de trabalho, "a lei seguiu um caminho próprio. Não definiu a organização criminosa, desprezando a linha inicial do projeto. Não definiu, através de

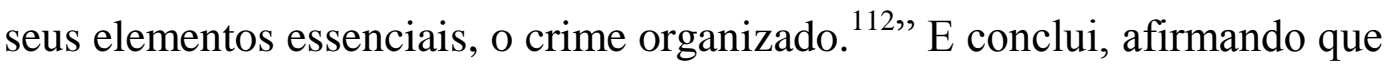
"não foi boa essa orientação. ${ }^{113 "}$

\footnotetext{
${ }^{112}$ FERNANDES, Antonio Scarance. O conceito de crime organizado na Lei 9.034. Disponível em: <http://www.ibccrim.org.br/site/boletim/exibir_artigos.php?id=1838>. Acesso em 26 ago. 2009.

${ }^{113}$ Ibid.
} 
Os doutrinadores não se entendiam sobre a correta incidência da lei. Surgiram, com isto, duas importantes exegeses salvacionistas, às quais nem seus defensores sentiam-se confortáveis.

Diante desse caos que se instaurou sobre a matéria, com injustiças sendo cometidas a todo o momento, pois, dependendo da corrente interpretativa que se filiasse o magistrado, situações que guardassem íntimas semelhanças poderiam ter um ou outro resultado, fora proposto novo Projeto de Lei sobre a matéria, que embora tivesse como escopo positivar mais uma forma de coleta de provas (a infiltração policial), pôs fim à confusão conceitual entre quadrilha ou bando, organizações criminosas e associações criminosas, as quais, embora tenham traços semelhantes, juridicamente não se confundem. Assim sendo, em 2001, foi promulgada a Lei 10.217 com intuito de promover alterações no texto da lei anterior.

Pecou a nova lei, contudo, ao manter no texto a expressão quadrilha ou bando e, principalmente, ao olvidar-se de positivar o que se entende por organizações criminosas. Tal fato levou a melhor doutrina a negar eficácia a todos os artigos que tratam exclusivamente sobre o tema, bem como a eficácia parcial de outros que, embora não exclusivamente, também remetem às organizações criminosas, tal qual o $\S^{\circ}$ do artigo $1^{\circ}$ da Lei $9.613 / 1996^{114}$.

Esse é, portanto, o cenário em que vivemos. Temos uma lei, fruto do Direito penal de emergência, com fortes traços do Direito penal do inimigo, que deveria definir o que é uma organização criminosa, mas que não o fez, tornando, portanto, inoperantes diversos dos seus artigos, bem como de outras leis, que remetem o interprete a esta forma de associação indefinida, vez que pelo princípio da legalidade não se pode admitir que se restrinjam

\footnotetext{
${ }^{114}$ Art. $1^{\circ}$ Ocultar ou dissimular a natureza, origem, localização, disposição, movimentação ou propriedade de bens, direitos ou valores provenientes, direta ou indiretamente, de crime: (...)

$\S 4^{\circ}$ A pena será aumentada de um a dois terços, nos casos previstos nos incisos I a VI do caput deste artigo, se o crime for cometido de forma habitual ou por intermédio de organização criminosa.
} 
direitos e garantias fundamentais sem um conceito hermético que somente a lei é capaz de nos fornecer.

Nas palavras de Luiz Flávio Gomes:

"Ao legislador incumbe a tarefa urgente de definir, em lei, o que devemos entender por organização criminosa. Enquanto isso não ocorrer, como afirmamos e veremos, boa parte da Lei $9.034 / 95$ passou a ser letra morta. A não ser que algum magistrado venha a usurpar a tarefa do legislador e diga do que se trata. Mas até onde vão os limites da Constituição vigente, não se vislumbra a mínima possibilidade de qualquer juiz desempenhar esse anômalo papel (que violaria flagrantemente o princípio da legalidade). ${ }^{115}$,

Erradamente, nossos Tribunais têm buscado na Convenção de Palermo a sua conceituação, não obstante estejam, na prática, exercendo uma analogia in malam partem, visto que a Convenção de Palermo trata, tão somente, das organizações criminosas transnacionais, logo, incapaz de conceituar as organizações que não tenham tal natureza.

Novamente o jurista Luiz Flávio Gomes nos presenteia com seus claríssimos ensinamentos:

"Se a Convenção da ONU (Convenção de Palermo) diz respeito à criminalidade organizada transnacional, aplicá-la no direito interno para a criminalidade (uma espécie de criminalidade) que não reúne essa característica significa violar a garantia da lex stricta e admitir analogia contra o réu (analogia in malam partem ). Em direito penal só vale (contra o réu) o que está na lei. Se o fato está expressamente previsto na lei pode o Estado adotar medidas restritivas (dos direitos fundamentais) contra o réu. Se o fato não está expressamente previsto na lei (lei formal, aprovada pelo parlamento)nada pode ser feito contra ele.

A Convenção da ONU estabeleceu uma determinada forma (jurídica). Essa forma jurídica só pode ter incidência em relação aos fatos rigorosamente adequados a ela. Uma criminalidade interna não tem nada a ver com criminalidade internacional ou transnacional. A divergência que existe entre a realidade (os fatos) e a forma jurídica criada (criminalidade transnacional) nos conduz a concluir que essa forma jurídica é inaplicável para fatos que não condizem com o seu conteúdo estrito. ${ }^{116, "}$

Sob a influência da Convenção internacional supramencionada, vimos ainda que tramita no Congresso Nacional o PLS 150/2006 com o objetivo criar o tipo penal de organização criminosa, solução esta que

115 GOMES, Luiz Flávio. Que Se Entende por Crime Organizado (Parte 1). Disponível em: <http://www.lfg.com.br/public_html/article.php?story=20100301093925108>. Acesso em 26 mar. 2010.

116 Id., Que se entende por crime organizado (Parte 3). Disponível em: $<$ http://www.lfg.com.br/public_html/article.php?story=20100301101842942>. Acesso em 04 mar. 2010. 
tentamos demonstrar não ser a saída correta, vez que se criaria um novo problema, desta vez referente a inconstitucionalidade do tipo penal que se pretende criar.

Assim sendo, conforme acima colacionado, defende o jurista Luiz Flávio Gomes, o entendimento de que se tornaram letra morta, isto é, perderam sua eficácia, os dispositivos legais que remetem o interprete e o magistrado ao conceito de organização criminosa, contudo, trata-se de:

"perda de eficácia (por não sabermos o que se entende por organização criminosa), não de revogação (perda de vigência). No dia em que o legislador revelar o conteúdo desse conceito vago, tais dispositivos legais voltarão a ter eficácia. Por ora continuam vigentes, mas não podem ser aplicados. ${ }^{117}$,"

O que nos leva a concluir que os problemas apontados neste trabalho se extinguirão no momento em que o legislador pátrio modificar a lei que versa sobre as organizações criminosas, fazendo constar, no texto legal, o seu conceito. Todavia, não podem descartar os esforços doutrinários, como visto nas tentativas anteriores, sob o risco de faltarem com os caracteres essenciais desta forma associativa qualificada.

Sobre a questão, Luiz Flávio Gomes aduz que:

"A ciência criminológica, de qualquer modo, já conta com incontáveis estudos sobre as organizações criminosas. Dentre tantas outras, são apontadas como suas características marcantes: hierarquia estrutural, planejamento empresarial, claro objetivo de lucros, uso de meios tecnológicos avançados, recrutamento de pessoas, divisão funcional de atividades, conexão estrutural ou funcional com o poder público elou com o poder político, oferta de prestações sociais, divisão territorial das atividades, alto poder de intimidação, alta capacitação para a fraude, conexão local, regional, nacional ou internacional com outras organizações etc. ${ }^{118, "}$

Já Marcelo Batlouni Mendroni ${ }^{119}$, analisando os elementos das organizações criminosas clássicas, identifica como características principais a presença de estrutura hierárquico-piramidal, com no mínimo três níveis

\footnotetext{
${ }^{117}$ GOMES, Luiz Flávio. Crime organizado: que se entende por isso depois da Lei n. 10.217, de 11.04.01? (Apontamentos sobre a perda de eficácia de grande parte da Lei 9.034/95). Disponível em 〈http://www.ibccrim.org.br/site/artigos/_imprime.php?jur_id=928〉. Acesso em 26 ago. 2009.

118 Id., Que se entende por crime organizado (Parte 3). Disponível em: $<$ http://www.lfg.com.br/public_html/article.php?story=20100301101842942〉. Consultado em 04 mar. 2010.

${ }^{119}$ MENDRONI, Marcelo Bartlouni. Crime organizado: Aspectos gerais e mecanismos legais. $3^{\text {a }}$ ed.. São Paulo: Atlas, 2009. p. 33 e seguintes.
} 
identificáveis, quais sejam: chefes, gerentes e "aviões"; divisão direcionada de tarefas; membros restritos; agentes públicos participantes ou envolvidos; orientação para a obtenção de dinheiro e poder; domínio territorial; diversificação das atividades; mescla de atividades lícitas com ilícitas e uso de violência.

Concluímos, assim, pela indispensabilidade da atuação do legislativo, em positivar o conceito de organização criminosa, para que os dispositivos legais que a ela fazem referência possam ter eficácia, entendimento este defendido por Luiz Flávio Gomes, conforme a transcrição que trouxemos anteriormente. No entanto, deve o legislador buscar os elementos essenciais dados pela doutrina, que embora discorde sobre algumas de suas características, convergem sobre os pontos nodais do conceito que se busca. Enquanto isso não ocorrer, impossível é a aplicação dos artigos que versam sobre as "organizações criminosas" e que restringem direitos e garantias processuais do acusado ou investigado, em respeito ao princípio da legalidade. 


\section{Bibliografia}

BATISTA, Nilo. Mídia e Sistema Penal no Capitalismo Tardio. 20 p. Disponível em <www.bocc.ubi.pt/.../batista-nilo-midia-sistema-penal.pdf>. Acesso em 12 mai. 2010.

BECHARA, Ana Elisa Liberatore S. "Caso Isabella": violência, mídia e direito penal de emergência. Disponível em http://www.ibccrim.org.br/site/boletim/exibir_artigos.php?id=3652>. Acesso em 12 mai. 2010.

BIANCHINI, Alice; MOLINA, Antonio García-Pablos de; GOMES, Luiz Flávio. Direito Penal: Introdução e princípios fundamentais. $2^{\mathrm{a}} \mathrm{ed}$.. rev. atual. e ampl.. Coleção ciências criminais. vol1 (Coord.) GOMES, Luiz Flávio; CUNHA, Rogério Sanches. São Paulo: Revista dos Tribunais, 2009. $411 \mathrm{p}$.

CAPEZ, Fernando. Curso de Direito Penal: Legislação Penal Especial, volume 4. 4a ed.. São Paulo: Saraiva, 2009. 818 p.

DOTTI, René Ariel. Prefácio. In. PITOMBO, Antonio Sergio Altieri de Moraes. Organizações criminosas: nova perspectiva do tipo legal. São Paulo: Revista dos Tribunais, 2009. p. 09 - 22.

FERNANDES, Antonio Scarance. O conceito de crime organizado na Lei 9.034 . Disponível em: <http://www.ibccrim.org.br/site/boletim/exibir_artigos.php?id=1838>. Acesso em 26 ago. 2009.

GOMES, Luiz Flávio. Crime organizado: que se entende por isso depois da Lei n. 10.217, de 11.04.01? (Apontamentos sobre a perda de eficácia de grande parte da Lei 9.034/95). Disponível em <http://www.ibccrim.org.br/site/artigos/_imprime.php?jur_id=928>. Acesso em 26 ago. 2009. 
GOMES, Luiz Flávio. Direito penal do inimigo (ou inimigos do Direito penal).

em $<$ http://www.revistajuridicaunicoc.com.br/midia/arquivos/ArquivoID_47.pd f>. Acesso em 12 mai. 2010.

GOMES, Luiz Flávio. Mídia e Direito Penal. Em 2009, o populismo penal pode explodir. $\quad$ Disponível em $\langle$ http://jus2.uol.com.br/doutrina/texto.asp?id=12274〉. Acesso em 12 mai. 2010.

GOMES, Luiz Flávio. Que se entende por crime organizado. Disponível em <http://jus2.uol.com.br/doutrina/texto.asp?id=12274>. Acesso em 12 mai. 2010.

GOMES, Luiz Flávio. Que se entende por crime organizado (Parte 1). Disponível em: <http://www.lfg.com.br/public_html/article.php?story=2010030109392510 8>. Acesso em 26 mar. 2010.

GOMES, Luiz Flávio. Que se entende por crime organizado (Parte 2). Disponível em: <http://www.lfg.com.br/public_html/article.php?story=2010030109514167 1>. Acesso em 26 mar. 2010.

GOMES, Luiz Flávio. Que se entende por crime organizado (Parte 3). Disponível em: <http://www.lfg.com.br/public_html/article.php?story=2010030110184294 2>. Acesso em 04 mar. 2010.

GRECO, Luís. "Princípio da ofensividade" e crimes de perigo abstrato uma introdução ao debate sobre o bem jurídico e as estruturas do delito. In Revista Brasileira de Ciências Criminais. volume 49, 2004. p. 89 - 147.

GRECO, Rogério. Curso de Direito Penal. $7^{\mathrm{a}}$ ed.. Rio de Janeiro: Impetus, 2006. 823 p. 
JESUS, Damásio E. de. Código Penal Anotado. $17^{a}$ ed.. São Paulo: Saraiva, 2005. $1181 \mathrm{p}$.

LEITÃO JÚNIOR, Joaquim. Qual a diferença entre o direito penal do autor $e$ direito penal dos fatos? Disponível em $<$ http://www.lfg.com.br/public_html/article.php?story=2008091816460666 4> Acesso em 05 jun. 2010.

LOPES, Cláudio. O Direito penal de emergência, os microssistemas, o discurso pan-penalista e o caráter limitador do princípio penal de $\begin{array}{llll}\text { legalidade } & \text { estrita. } & \text { Disponível }\end{array}$ $<$ http://www.ibccrim.org.br/site/artigos/capa.php?jur_id=7589>. Acesso em 17 mai. 2010.

MENDRONI, Marcelo Bartlouni. Crime organizado: Aspectos gerais e mecanismos legais. $3^{\text {a }}$ ed.. São Paulo: Atlas, 2009. 450 p.

MORAES, Alexandre de. Direito Constitucional. 20ª ed.. São Paulo: Atlas, 2006. $972 \mathrm{p}$.

PACHECO, Rafael. Crime organizado: medidas de controle e infiltração policial. Coritiba: Joruá, 2008. 215 p.

PITOMBO, Antonio Sergio Altieri de Moraes. Organizações criminosas: nova perspectiva do tipo legal. São Paulo: Revista dos Tribunais, 2009. 236 p.

PORTAL Paraiba 1. Polícia desarticula na Paraíba quadrilha que comprava droga na Bolívia e vendia em 3 estados do Nordeste. Publicada em 13/05/2010 às 15:10. Disponível em <http://oglobo.globo.com/cidades/mat/2010/05/13/policia-desarticula-naparaiba-quadrilha-que-comprava-droga-na-bolivia-vendia-em-3-estados-donordeste-916573734.asp>. Acesso em 13 mai. 2010.

ROMERO, Diogo. Reflexões sobre os crimes de perigo abstrato. Disponível em <http://jus2.uol.com.br/doutrina/texto.asp?id=5722>. Acesso em 22 mai. 2010. 
SICA, Leonardo. Medidas de emergência, violência e crime organizado. Disponível em

<http://www.ibccrim.org.br/site/boletim/exibir_artigos.php?id=150>.

Acesso em 26 ago. 2009.

SILVA, Eduardo Araújo. Crime organizado: procedimento probatório. São Paulo: Atlas, 2009. 175 p.

SOUZA, Alexis Sales de Paula e. $O$ conceito de organização criminosa no direito comparado e na legislação brasileira. Disponível em 〈http://www.ibccrim.org.br/site/artigos/_imprime.php?jur_id=9531>. Acesso em 26 ago. 2009.

STF, ADI 3112 / DF. Rel. Min. Ricardo Lewandowski., Brasília, 02 mai. 2007

STF, HC 86.395-7/SP. Segunda Turma. Relator Ministro Gilmar Mendes. Brasília, 06 nov. 2006

STF, HC 96.007-SP. Rel. Ministro Marco Aurélio.

TRF $1^{\circ}$ região, Habeas Corpus $n^{\circ}$ 2004.01.00.000468-5/MT. Rel. Juiz Plauto Ribeiro. Mato Grosso, 17 fev. 2004.

VIEIRA, Ana Lúcia Menezes. Processo penal e mídia. São Paulo: Revista dos Tribunais, 2003. 288 p.

ZAFFARONI, E. Raúl. O Inimigo no Direito Penal. Rio de Janeiro: Revan e Instituto Carioca de Criminologia, 2007, 224 p. 


\section{Anexo A - DECRETO 5.015, de 12 de março de 2004}

\section{Promulga a Convenção das Nações Unidas contra o Crime Organizado}

Transnacional.

O PRESIDENTE DA REPÚBLICA, no uso da atribuição que lhe confere o art. 84, inciso IV, da Constituição, e

Considerando que o Congresso Nacional aprovou, por meio do Decreto Legislativo n⿳⺈ 231, de 29 de maio de 2003, o texto da Convenção das Nações Unidas contra o Crime Organizado Transnacional, adotada em Nova York, em 15 de novembro de 2000;

Considerando que o Governo brasileiro depositou o instrumento de ratificação junto à Secretaria-Geral da ONU, em 29 de janeiro de 2004;

Considerando que a Convenção entrou em vigor internacional, em 29 de setembro de 2003, e entrou em vigor para o Brasil, em 28 de fevereiro de 2004

\section{DECRETA:}

Art. $1^{0}$ A Convenção das Nações Unidas contra o Crime Organizado Transnacional, adotada em Nova York, em 15 de novembro de 2000, apensa por cópia ao presente Decreto, será executada e cumprida tão inteiramente como nela se contém.

Art $2^{\underline{0}}$ São sujeitos à aprovação do Congresso Nacional quaisquer atos que possam resultar em revisão da referida Convenção ou que acarretem encargos ou compromissos gravosos ao patrimônio nacional, nos termos do art. 49, inciso I, da Constituição.

Art. $3^{\circ}$ Este Decreto entra em vigor na data de sua publicação.

Brasília, 12 de março de 2004; 183ํำ da Independência e $116^{\circ}$ da República. LUIZ INÁCIO LULA DA SILVA Samuel Pinheiro Guimarães Neto 


\section{CONVENĊ̃̃O DAS NAÇÕES UNIDAS}

\section{CONTRA O CRIME ORGANIZADO TRANSNACIONAL}

\section{Artigo 1}

\section{Objetivo}

O objetivo da presente Convenção consiste em promover a cooperação para prevenir e combater mais eficazmente a criminalidade organizada transnacional.

\section{Artigo 2}

\section{Terminologia}

Para efeitos da presente Convenção, entende-se por:

a) "Grupo criminoso organizado" - grupo estruturado de três ou mais pessoas, existente há algum tempo e atuando concertadamente com o propósito de cometer uma ou mais infrações graves ou enunciadas na presente Convenção, com a intenção de obter, direta ou indiretamente, um benefício econômico ou outro benefício material;

b) "Infração grave" - ato que constitua infração punível com uma pena de privação de liberdade, cujo máximo não seja inferior a quatro anos ou com pena superior;

c) "Grupo estruturado" - grupo formado de maneira não fortuita para a prática imediata de uma infração, ainda que os seus membros não tenham funções formalmente definidas, que não haja continuidade na sua composição e que não disponha de uma estrutura elaborada;

d) "Bens" - os ativos de qualquer tipo, corpóreos ou incorpóreos, móveis ou imóveis, tangíveis ou intangíveis, e os documentos ou instrumentos jurídicos que atestem a propriedade ou outros direitos sobre os referidos ativos;

e) "Produto do crime" - os bens de qualquer tipo, provenientes, direta ou indiretamente, da prática de um crime; 
f) "Bloqueio" ou "apreensão" - a proibição temporária de transferir, converter, dispor ou movimentar bens, ou a custódia ou controle temporário de bens, por decisão de um tribunal ou de outra autoridade competente;

g) "Confisco" - a privação com caráter definitivo de bens, por decisão de um tribunal ou outra autoridade competente;

h) "Infração principal" - qualquer infração de que derive um produto que possa passar a constituir objeto de uma infração definida no Artigo 6 da presente Convenção;

i) "Entrega vigiada" - a técnica que consiste em permitir que remessas ilícitas ou suspeitas saiam do território de um ou mais Estados, os atravessem ou neles entrem, com o conhecimento e sob o controle das suas autoridades competentes, com a finalidade de investigar infrações e identificar as pessoas envolvidas na sua prática;

j) "Organização regional de integração econômica" - uma organização constituída por Estados soberanos de uma região determinada, para a qual estes Estados tenham transferido competências nas questões reguladas pela presente Convenção e que tenha sido devidamente mandatada, em conformidade com os seus procedimentos internos, para assinar, ratificar, aceitar ou aprovar a Convenção ou a ela aderir; as referências aos "Estados Partes" constantes da presente Convenção são aplicáveis a estas organizações, nos limites das suas competências.

\section{Artigo 3}

\section{Âmbito de aplicação}

1. Salvo disposição em contrário, a presente Convenção é aplicável à prevenção, investigação, instrução e julgamento de:

a) Infrações enunciadas nos Artigos 5, 6, 8 e 23 da presente Convenção; e

b) Infrações graves, na acepção do Artigo 2 da presente Convenção; 
sempre que tais infrações sejam de caráter transnacional e envolvam um grupo criminoso organizado;

2. Para efeitos do parágrafo 1 do presente Artigo, a infração será de caráter transnacional se:

a) For cometida em mais de um Estado;

b) For cometida num só Estado, mas uma parte substancial da sua preparação, planeamento, direção e controle tenha lugar em outro Estado;

c) For cometida num só Estado, mas envolva a participação de um grupo criminoso organizado que pratique atividades criminosas em mais de um Estado; ou

d) For cometida num só Estado, mas produza efeitos substanciais noutro Estado.

\section{Artigo 4}

\section{Proteção da soberania}

1. Os Estados Partes cumprirão as suas obrigações decorrentes da presente Convenção no respeito pelos princípios da igualdade soberana e da integridade territorial dos Estados, bem como da não-ingerência nos assuntos internos de outros Estados.

2. O disposto na presente Convenção não autoriza qualquer Estado Parte a exercer, em território de outro Estado, jurisdição ou funções que o direito interno desse Estado reserve exclusivamente às suas autoridades.

\section{Artigo 5}

\section{Criminalização da participação em um grupo criminoso organizado}

1. Cada Estado Parte adotará as medidas legislativas ou outras que sejam necessárias para caracterizar como infração penal, quando praticado intencionalmente:

a) Um dos atos seguintes, ou ambos, enquanto infrações penais distintas das que impliquem a tentativa ou a consumação da atividade criminosa: 
i) $\mathrm{O}$ entendimento com uma ou mais pessoas para a prática de uma infração grave, com uma intenção direta ou indiretamente relacionada com a obtenção de um benefício econômico ou outro benefício material e, quando assim prescrever o direito interno, envolvendo um ato praticado por um dos participantes para concretizar o que foi acordado ou envolvendo a participação de um grupo criminoso organizado;

ii) A conduta de qualquer pessoa que, conhecendo a finalidade e a atividade criminosa geral de um grupo criminoso organizado, ou a sua intenção de cometer as infrações em questão, participe ativamente em:

a. Atividades ilícitas do grupo criminoso organizado;

b. Outras atividades do grupo criminoso organizado, sabendo que a sua participação contribuirá para a finalidade criminosa acima referida;

b) $\mathrm{O}$ ato de organizar, dirigir, ajudar, incitar, facilitar ou aconselhar a prática de uma infração grave que envolva a participação de um grupo criminoso organizado.

2. O conhecimento, a intenção, a finalidade, a motivação ou o acordo a que se refere o parágrafo 1 do presente Artigo poderão inferir-se de circunstâncias factuais objetivas.

3. Os Estados Partes cujo direito interno condicione a incriminação pelas infrações referidas no inciso i) da alínea a) do parágrafo 1 do presente Artigo ao envolvimento de um grupo criminoso organizado diligenciarão no sentido de que o seu direito interno abranja todas as infrações graves que envolvam a participação de grupos criminosos organizados. Estes Estados Partes, assim como os Estados Partes cujo direito interno condicione a incriminação pelas infrações definidas no inciso i) da alínea a) do parágrafo 1 do presente Artigo à prática de um ato concertado, informarão deste fato o Secretário Geral da Organização das Nações Unidas, no momento da assinatura ou do depósito do seu instrumento de ratificação, aceitação, aprovação ou adesão à presente Convenção. 


\section{Artigo 6}

\section{Criminalização da lavagem do produto do crime}

1. Cada Estado Parte adotará, em conformidade com os princípios fundamentais do seu direito interno, as medidas legislativas ou outras que sejam necessárias para caracterizar como infração penal, quando praticada intencionalmente:

a) i) A conversão ou transferência de bens, quando quem o faz tem conhecimento de que esses bens são produto do crime, com o propósito de ocultar ou dissimular a origem ilícita dos bens ou ajudar qualquer pessoa envolvida na prática da infração principal a furtar-se às conseqüências jurídicas dos seus atos;

ii) A ocultação ou dissimulação da verdadeira natureza, origem, localização, disposição, movimentação ou propriedade de bens ou direitos a eles relativos, sabendo o seu autor que os ditos bens são produto do crime;

b) e, sob reserva dos conceitos fundamentais do seu ordenamento jurídico:

i) A aquisição, posse ou utilização de bens, sabendo aquele que os adquire, possui ou utiliza, no momento da recepção, que são produto do crime;

ii) A participação na prática de uma das infrações enunciadas no presente Artigo, assim como qualquer forma de associação, acordo, tentativa ou cumplicidade, pela prestação de assistência, ajuda ou aconselhamento no sentido da sua prática.

2. Para efeitos da aplicação do parágrafo 1 do presente Artigo:

a) Cada Estado Parte procurará aplicar o parágrafo 1 do presente Artigo à mais ampla gama possível de infrações principais;

b) Cada Estado Parte considerará como infrações principais todas as infrações graves, na acepção do Artigo 2 da presente Convenção, e as infrações enunciadas nos seus Artigos 5, 8 e 23. Os Estados Partes cuja legislação estabeleça uma lista de infrações principais específicas incluirá 
entre estas, pelo menos, uma gama completa de infrações relacionadas com grupos criminosos organizados;

c) Para efeitos da alínea b), as infrações principais incluirão as infrações cometidas tanto dentro como fora da jurisdição do Estado Parte interessado. No entanto, as infrações cometidas fora da jurisdição de um Estado Parte só constituirão infração principal quando o ato correspondente constitua infração penal à luz do direito interno do Estado em que tenha sido praticado e constitua infração penal à luz do direito interno do Estado Parte que aplique o presente Artigo se o crime aí tivesse sido cometido;

d) Cada Estado Parte fornecerá ao Secretário Geral das Nações Unidas uma cópia ou descrição das suas leis destinadas a dar aplicação ao presente Artigo e de qualquer alteração posterior;

e) Se assim o exigirem os princípios fundamentais do direito interno de um Estado Parte, poderá estabelecer-se que as infrações enunciadas no parágrafo 1 do presente Artigo não sejam aplicáveis às pessoas que tenham cometido a infração principal;

f) $\mathrm{O}$ conhecimento, a intenção ou a motivação, enquanto elementos constitutivos de uma infração enunciada no parágrafo 1 do presente Artigo, poderão inferir-se de circunstâncias fatuais objetivas.

\section{Artigo 7}

\section{Medidas para combater a lavagem de dinheiro}

\section{Cada Estado Parte:}

a) Instituirá um regime interno completo de regulamentação e controle dos bancos e instituições financeiras não bancárias e, quando se justifique, de outros organismos especialmente susceptíveis de ser utilizados para a lavagem de dinheiro, dentro dos limites da sua competência, a fim de prevenir e detectar qualquer forma de lavagem de dinheiro, sendo nesse regime enfatizados os requisitos relativos à identificação do cliente, ao registro das operações e à denúncia de operações suspeitas; 
b) Garantirá, sem prejuízo da aplicação dos Artigos 18 e 27 da presente Convenção, que as autoridades responsáveis pela administração, regulamentação, detecção e repressão e outras autoridades responsáveis pelo combate à lavagem de dinheiro (incluindo, quando tal esteja previsto no seu direito interno, as autoridades judiciais), tenham a capacidade de cooperar e trocar informações em âmbito nacional e internacional, em conformidade com as condições prescritas no direito interno, e, para esse fim, considerará a possibilidade de criar um serviço de informação financeira que funcione como centro nacional de coleta, análise e difusão de informação relativa a eventuais atividades de lavagem de dinheiro.

2. Os Estados Partes considerarão a possibilidade de aplicar medidas viáveis para detectar e vigiar o movimento transfronteiriço de numerário e de títulos negociáveis, no respeito pelas garantias relativas à legítima utilização da informação e sem, por qualquer forma, restringir a circulação de capitais lícitos. Estas medidas poderão incluir a exigência de que os particulares e as entidades comerciais notifiquem as transferências transfronteiriças de quantias elevadas em numerário e títulos negociáveis.

3. Ao instituírem, nos termos do presente Artigo, um regime interno de regulamentação e controle, e sem prejuízo do disposto em qualquer outro artigo da presente Convenção, todos os Estados Partes são instados a utilizar como orientação as iniciativas pertinentes tomadas pelas organizações regionais, inter-regionais e multilaterais para combater a lavagem de dinheiro.

4. Os Estados Partes diligenciarão no sentido de desenvolver e promover a cooperação à escala mundial, regional, sub-regional e bilateral entre as autoridades judiciais, os organismos de detecção e repressão e as autoridades de regulamentação financeira, a fim de combater a lavagem de dinheiro. 


\section{Artigo 8}

\section{Criminalização da corrupção}

1. Cada Estado Parte adotará as medidas legislativas e outras que sejam necessárias para caracterizar como infrações penais os seguintes atos, quando intencionalmente cometidos:

a) Prometer, oferecer ou conceder a um agente público, direta ou indiretamente, um benefício indevido, em seu proveito próprio ou de outra pessoa ou entidade, a fim de praticar ou se abster de praticar um ato no desempenho das suas funções oficiais;

b) Por um agente público, pedir ou aceitar, direta ou indiretamente, um benefício indevido, para si ou para outra pessoa ou entidade, a fim de praticar ou se abster de praticar um ato no desempenho das suas funções oficiais.

2. Cada Estado Parte considerará a possibilidade de adotar as medidas legislativas ou outras que sejam necessárias para conferir o caracter de infração penal aos atos enunciados no parágrafo 1 do presente Artigo que envolvam um agente público estrangeiro ou um funcionário internacional. Do mesmo modo, cada Estado Parte considerará a possibilidade de conferir o caracter de infração penal a outras formas de corrupção.

3. Cada Estado Parte adotará igualmente as medidas necessárias para conferir o caráter de infração penal à cumplicidade na prática de uma infração enunciada no presente Artigo.

4. Para efeitos do parágrafo 1 do presente Artigo e do Artigo 9, a expressão "agente público" designa, além do funcionário público, qualquer pessoa que preste um serviço público, tal como a expressão é definida no direito interno e aplicada no direito penal do Estado Parte onde a pessoa em questão exerce as suas funções. 


\section{Artigo 9}

\section{Medidas contra a corrupção}

1. Para além das medidas enunciadas no Artigo 8 da presente Convenção, cada Estado Parte, na medida em que seja procedente e conforme ao seu ordenamento jurídico, adotará medidas eficazes de ordem legislativa, administrativa ou outra para promover a integridade e prevenir, detectar e punir a corrupção dos agentes públicos.

2. Cada Estado Parte tomará medidas no sentido de se assegurar de que as suas autoridades atuam eficazmente em matéria de prevenção, deteç̧ão e repressão da corrupção de agentes públicos, inclusivamente conferindo a essas autoridades independência suficiente para impedir qualquer influência indevida sobre a sua atuação.

\section{Artigo 10}

\section{Responsabilidade das pessoas jurídicas}

1. Cada Estado Parte adotará as medidas necessárias, em conformidade com o seu ordenamento jurídico, para responsabilizar pessoas jurídicas que participem em infrações graves envolvendo um grupo criminoso organizado e que cometam as infrações enunciadas nos Artigos 5, 6, 8 e 23 da presente Convenção.

2. No respeito pelo ordenamento jurídico do Estado Parte, a responsabilidade das pessoas jurídicas poderá ser penal, civil ou administrativa.

3. A responsabilidade das pessoas jurídicas não obstará à responsabilidade penal das pessoas físicas que tenham cometido as infrações.

4. Cada Estado Parte diligenciará, em especial, no sentido de que as pessoas jurídicas consideradas responsáveis em conformidade com o presente Artigo sejam objeto de sanções eficazes, proporcionais e acautelatórias, de natureza penal e não penal, incluindo sanções pecuniárias. 


\section{Artigo 11}

\section{Processos judiciais, julgamento e sanções}

1. Cada Estado Parte tornará a prática de qualquer infração enunciada nos Artigos 5, 6, 8 e 23 da presente Convenção passível de sanções que tenham em conta a gravidade dessa infração.

2. Cada Estado Parte diligenciará para que qualquer poder judicial discricionário conferido pelo seu direito interno e relativo a processos judiciais contra indivíduos por infrações previstas na presente Convenção seja exercido de forma a otimizar a eficácia das medidas de detecção e de repressão destas infrações, tendo na devida conta a necessidade de exercer um efeito cautelar da sua prática.

3. No caso de infrações como as enunciadas nos Artigos 5, 6, 8 e 23 da presente Convenção, cada Estado Parte tomará as medidas apropriadas, em conformidade com o seu direito interno, e tendo na devida conta os direitos da defesa, para que as condições a que estão sujeitas as decisões de aguardar julgamento em liberdade ou relativas ao processo de recurso tenham em consideração a necessidade de assegurar a presença do argüido em todo o processo penal ulterior.

4. Cada Estado Parte providenciará para que os seus tribunais ou outras autoridades competentes tenham presente a gravidade das infração previstas na presente Convenção quando considerarem a possibilidade de uma libertação antecipada ou condicional de pessoas reconhecidas como culpadas dessas infrações.

5. Sempre que as circunstâncias o justifiquem, cada Estado Parte determinará, no âmbito do seu direito interno, um prazo de prescrição prolongado, durante o qual poderá ter início o processo relativo a uma das infrações previstas na presente Convenção, devendo esse período ser mais longo quando o presumível autor da infração se tenha subtraído à justiça. 
6. Nenhuma das disposições da presente Convenção prejudica o princípio segundo o qual a definição das infrações nela enunciadas e dos meios jurídicos de defesa aplicáveis, bem como outros princípios jurídicos que rejam a legalidade das incriminações, são do foro exclusivo do direito interno desse Estado Parte, e segundo o qual as referidas infrações são objeto de procedimento judicial e punidas de acordo com o direito desse Estado Parte.

\section{Artigo 12}

\section{Confisco e apreensão}

1. Os Estados Partes adotarão, na medida em que o seu ordenamento jurídico interno o permita, as medidas necessárias para permitir o confisco:

a) Do produto das infrações previstas na presente Convenção ou de bens cujo valor corresponda ao desse produto;

b) Dos bens, equipamentos e outros instrumentos utilizados ou destinados a ser utilizados na prática das infrações previstas na presente Convenção.

2. Os Estados Partes tomarão as medidas necessárias para permitir a identificação, a localização, o embargo ou a apreensão dos bens referidos no parágrafo 1 do presente Artigo, para efeitos de eventual confisco.

3. Se o produto do crime tiver sido convertido, total ou parcialmente, noutros bens, estes últimos podem ser objeto das medidas previstas no presente Artigo, em substituição do referido produto.

4. Se o produto do crime tiver sido misturado com bens adquiridos legalmente, estes bens poderão, sem prejuízo das competências de embargo ou apreensão, ser confiscados até ao valor calculado do produto com que foram misturados.

5. As receitas ou outros benefícios obtidos com o produto do crime, os bens nos quais o produto tenha sido transformado ou convertido ou os bens com que tenha sido misturado podem também ser objeto das medidas previstas 
no presente Artigo, da mesma forma e na mesma medida que o produto do crime.

6. Para efeitos do presente Artigo e do Artigo 13, cada Estado Parte habilitará os seus tribunais ou outras autoridades competentes para ordenarem a apresentação ou a apreensão de documentos bancários, financeiros ou comerciais. Os Estados Partes não poderão invocar o sigilo bancário para se recusarem a aplicar as disposições do presente número.

7. Os Estados Partes poderão considerar a possibilidade de exigir que o autor de uma infração demonstre a proveniência lícita do presumido produto do crime ou de outros bens que possam ser objeto de confisco, na medida em que esta exigência esteja em conformidade com os princípios do seu direito interno e com a natureza do processo ou outros procedimentos judiciais.

8. As disposições do presente Artigo não deverão, em circunstância alguma, ser interpretadas de modo a afetar os direitos de terceiros de boa fé.

9. Nenhuma das disposições do presente Artigo prejudica o princípio segundo o qual as medidas nele previstas são definidas e aplicadas em conformidade com o direito interno de cada Estado Parte e segundo as disposições deste direito.

\section{Artigo 13}

\section{Cooperação internacional para efeitos de confisco}

1. Na medida em que o seu ordenamento jurídico interno o permita, um Estado Parte que tenha recebido de outro Estado Parte, competente para conhecer de uma infração prevista na presente Convenção, um pedido de confisco do produto do crime, bens, equipamentos ou outros instrumentos referidos no parágrafo 1 do Artigo 12 da presente Convenção que se encontrem no seu território, deverá:

a) Submeter o pedido às suas autoridades competentes, a fim de obter uma ordem de confisco e, se essa ordem for emitida, executá-la; ou 
b) Submeter às suas autoridades competentes, para que seja executada conforme o solicitado, a decisão de confisco emitida por um tribunal situado no território do Estado Parte requerente, em conformidade com o parágrafo 1 do Artigo 12 da presente Convenção, em relação ao produto do crime, bens, equipamentos ou outros instrumentos referidos no parágrafo 1 do Artigo 12 que se encontrem no território do Estado Parte requerido.

2. Quando um pedido for feito por outro Estado Parte competente para conhecer de uma infração prevista na presente Convenção, o Estado Parte requerido tomará medidas para identificar, localizar, embargar ou apreender o produto do crime, os bens, os equipamentos ou os outros instrumentos referidos no parágrafo 1 do Artigo 12 da presente Convenção, com vista a um eventual confisco que venha a ser ordenado, seja pelo Estado Parte requerente, seja, na seqüência de um pedido formulado ao abrigo do parágrafo 1 do presente Artigo, pelo Estado Parte requerido.

3. As disposições do Artigo 18 da presente Convenção aplicam-se mutatis mutandis ao presente Artigo. Para além das informações referidas no parágrafo 15 do Artigo 18, os pedidos feitos em conformidade com o presente Artigo deverão conter:

a) Quando o pedido for feito ao abrigo da alínea a) do parágrafo 1 do presente Artigo, uma descrição dos bens a confiscar e uma exposição dos fatos em que o Estado Parte requerente se baseia, que permita ao Estado Parte requerido obter uma decisão de confisco em conformidade com o seu direito interno;

b) Quando o pedido for feito ao abrigo da alínea b) do parágrafo 1 do presente Artigo, uma cópia legalmente admissível da decisão de confisco emitida pelo Estado Parte requerente em que se baseia o pedido, uma exposição dos fatos e informações sobre os limites em que é pedida a execução da decisão; 
c) Quando o pedido for feito ao abrigo do parágrafo 2 do presente Artigo, uma exposição dos fatos em que se baseia o Estado Parte requerente e uma descrição das medidas pedidas.

4. As decisões ou medidas previstas nos parágrafo 1 e parágrafo 2 do presente Artigo são tomadas pelo Estado Parte requerido em conformidade com o seu direito interno e segundo as disposições do mesmo direito, e em conformidade com as suas regras processuais ou com qualquer tratado, acordo ou protocolo bilateral ou multilateral que o ligue ao Estado Parte requerente.

5. Cada Estado Parte enviará ao Secretário Geral da Organização das Nações Unidas uma cópia das suas leis e regulamentos destinados a dar aplicação ao presente Artigo, bem como uma cópia de qualquer alteração ulteriormente introduzida a estas leis e regulamentos ou uma descrição destas leis, regulamentos e alterações ulteriores.

6. Se um Estado Parte decidir condicionar a adoção das medidas previstas nos parágrafos 1 e 2 do presente Artigo à existência de um tratado na matéria, deverá considerar a presente Convenção como uma base jurídica necessária e suficiente para o efeito.

7. Um Estado Parte poderá recusar a cooperação que lhe é solicitada ao abrigo do presente Artigo, caso a infração a que se refere o pedido não seja abrangida pela presente Convenção.

8. As disposiçõoes do presente Artigo não deverão, em circunstância alguma, ser interpretadas de modo a afetar os direitos de terceiros de boa fé.

9. Os Estados Partes considerarão a possibilidade de celebrar tratados, acordos ou protocolos bilaterais ou multilaterais com o objetivo de reforçar a eficácia da cooperação internacional desenvolvida para efeitos do presente Artigo. 


\section{Artigo 14}

\section{Disposição do produto do crime ou dos bens confiscados}

1. Um Estado Parte que confisque o produto do crime ou bens, em aplicação do Artigo 12 ou do parágrafo 1 do Artigo 13 da presente Convenção, disporá deles de acordo com o seu direito interno e os seus procedimentos administrativos.

2. Quando os Estados Partes agirem a pedido de outro Estado Parte em aplicação do Artigo 13 da presente Convenção, deverão, na medida em que o permita o seu direito interno e se tal lhes for solicitado, considerar prioritariamente a restituição do produto do crime ou dos bens confiscados ao Estado Parte requerente, para que este último possa indenizar as vítimas da infração ou restituir este produto do crime ou estes bens aos seus legítimos proprietários.

3. Quando um Estado Parte atuar a pedido de um outro Estado Parte em aplicação dos Artigos 12 e 13 da presente Convenção, poderá considerar especialmente a celebração de acordos ou protocolos que prevejam:

a) Destinar o valor deste produto ou destes bens, ou os fundos provenientes da sua venda, ou uma parte destes fundos, à conta criada em aplicação da alínea c) do parágrafo 2 do Artigo 30 da presente Convenção e a organismos intergovernamentais especializados na luta contra a criminalidade organizada;

b) Repartir com outros Estados Partes, sistemática ou casuisticamente, este produto ou estes bens, ou os fundos provenientes da respectiva venda, em conformidade com o seu direito interno ou os seus procedimentos administrativos. 


\section{Artigo 15}

\section{Jurisdição}

1. Cada Estado Parte adotará as medidas necessárias para estabelecer a sua competência jurisdicional em relação às infrações enunciadas nos Artigos 5, 6, 8 e 23 da presente Convenção, nos seguintes casos:

a) Quando a infração for cometida no seu território; ou

b) Quando a infração for cometida a bordo de um navio que arvore a sua bandeira ou a bordo de uma aeronave matriculada em conformidade com o seu direito interno no momento em que a referida infração for cometida.

2. Sem prejuízo do disposto no Artigo 4 da presente Convenção, um Estado Parte poderá igualmente estabelecer a sua competência jurisdicional em relação a qualquer destas infrações, nos seguintes casos:

a) Quando a infração for cometida contra um dos seus cidadãos;

b) Quando a infração for cometida por um dos seus cidadãos ou por uma pessoa apátrida residente habitualmente no seu território; ou

c) Quando a infração for:

i) Uma das previstas no parágrafo 1 do Artigo 5 da presente Convenção e praticada fora do seu território, com a intenção de cometer uma infração grave no seu território;

ii) Uma das previstas no inciso ii) da alínea b) do parágrafo 1 do Artigo 6 da presente Convenção e praticada fora do seu território com a intenção de cometer, no seu território, uma das infrações enunciadas nos incisos i) ou ii) da alínea a) ou i) da alínea b) do parágrafo 1 do Artigo 6 da presente Convenção.

3. Para efeitos do parágrafo 10 do Artigo 16 da presente Convenção, cada Estado Parte adotará as medidas necessárias para estabelecer a sua competência jurisdicional em relação às infrações abrangidas pela presente Convenção quando o presumível autor se encontre no seu território e o 
Estado Parte não o extraditar pela única razão de se tratar de um seu cidadão.

4. Cada Estado Parte poderá igualmente adotar as medidas necessárias para estabelecer a sua competência jurisdicional em relação às infrações abrangidas pela presente Convenção quando o presumível autor se encontre no seu território e o Estado Parte não o extraditar.

5. Se um Estado Parte que exerça a sua competência jurisdicional por força dos parágrafos 1 e 2 do presente Artigo tiver sido notificado, ou por qualquer outra forma tiver tomado conhecimento, de que um ou vários Estados Partes estão a efetuar uma investigação ou iniciaram diligências ou um processo judicial tendo por objeto o mesmo ato, as autoridades competentes destes Estados Partes deverão consultar-se, da forma que for mais conveniente, para coordenar as suas ações.

6. Sem prejuízo das normas do direito internacional geral, a presente Convenção não excluirá o exercício de qualquer competência jurisdicional penal estabelecida por um Estado Parte em conformidade com o seu direito interno.

\section{Artigo 16}

\section{Extradição}

1. O presente Artigo aplica-se às infrações abrangidas pela presente Convenção ou nos casos em que um grupo criminoso organizado esteja implicado numa infração prevista nas alíneas a) ou b) do parágrafo 1 do Artigo 3 e em que a pessoa que é objeto do pedido de extradição se encontre no Estado Parte requerido, desde que a infração pela qual é pedida a extradição seja punível pelo direito interno do Estado Parte requerente e do Estado Parte requerido.

2. Se o pedido de extradição for motivado por várias infrações graves distintas, algumas das quais não se encontrem previstas no presente Artigo, 
o Estado Parte requerido pode igualmente aplicar o presente Artigo às referidas infrações.

3. Cada uma das infrações às quais se aplica o presente Artigo será considerada incluída, de pleno direito, entre as infrações que dão lugar a extradição em qualquer tratado de extradição em vigor entre os Estados Partes. Os Estados Partes comprometem-se a incluir estas infrações entre aquelas cujo autor pode ser extraditado em qualquer tratado de extradição que celebrem entre si.

4. Se um Estado Parte que condicione a extradição à existência de um tratado receber um pedido de extradição de um Estado Parte com o qual não celebrou tal tratado, poderá considerar a presente Convenção como fundamento jurídico da extradição quanto às infrações a que se aplique o presente Artigo.

5. Os Estados Partes que condicionem a extradição à existência de um tratado:

a) No momento do depósito do seu instrumento de ratificação, aceitação, aprovação ou adesão à presente Convenção, indicarão ao Secretário Geral da Organização das Nações Unidas se consideram a presente Convenção como fundamento jurídico para a cooperação com outros Estados Partes em matéria de extradição; e

b) Se não considerarem a presente Convenção como fundamento jurídico para cooperar em matéria de extradição, diligenciarão, se necessário, pela celebração de tratados de extradição com outros Estados Partes, a fim de darem aplicação ao presente Artigo.

6. Os Estados Partes que não condicionem a extradição à existência de um tratado reconhecerão entre si, às infrações às quais se aplica o presente Artigo, o caráter de infração cujo autor pode ser extraditado.

7. A extradição estará sujeita às condições previstas no direito interno do Estado Parte requerido ou em tratados de extradição aplicáveis, incluindo, 
nomeadamente, condições relativas à pena mínima requerida para uma extradição e aos motivos pelos quais o Estado Parte requerido pode recusar a extradição.

8. Os Estados Partes procurarão, sem prejuízo do seu direito interno, acelerar os processos de extradição e simplificar os requisitos em matéria de prova com eles relacionados, no que se refere às infrações a que se aplica o presente Artigo.

9. Sem prejuízo do disposto no seu direito interno e nos tratados de extradição que tenha celebrado, o Estado Parte requerido poderá, a pedido do Estado Parte requerente, se considerar que as circunstâncias o justificam e que existe urgência, colocar em detenção uma pessoa, presente no seu território, cuja extradição é pedida, ou adotar a seu respeito quaisquer outras medidas apropriadas para assegurar a sua presença no processo de extradição.

10. Um Estado Parte em cujo território se encontre o presumível autor da infração, se não extraditar esta pessoa a título de uma infração à qual se aplica o presente Artigo pelo único motivo de se tratar de um seu cidadão, deverá, a pedido do Estado Parte requerente da extradição, submeter o caso, sem demora excessiva, às suas autoridades competentes para efeitos de procedimento judicial. Estas autoridades tomarão a sua decisão e seguirão os trâmites do processo da mesma forma que em relação a qualquer outra infração grave, à luz do direito interno deste Estado Parte. Os Estados Partes interessados cooperarão entre si, nomeadamente em matéria processual e probatória, para assegurar a eficácia dos referidos atos judiciais.

11. Quando um Estado Parte, por força do seu direito interno, só estiver autorizado a extraditar ou, por qualquer outra forma, entregar um dos seus cidadãos na condição de que essa pessoa retorne seguidamente ao mesmo Estado Parte para cumprir a pena a que tenha sido condenada na seqüência do processo ou do procedimento que originou o pedido de extradição ou de 
entrega, e quando este Estado Parte e o Estado Parte requerente concordarem em relação a essa opção e a outras condições que considerem apropriadas, a extradição ou entrega condicional será suficiente para dar cumprimento à obrigação enunciada no parágrafo 10 do presente Artigo.

12. Se a extradição, pedida para efeitos de execução de uma pena, for recusada porque a pessoa que é objeto deste pedido é um cidadão do Estado Parte requerido, este, se o seu direito interno o permitir, em conformidade com as prescrições deste direito e a pedido do Estado Parte requerente, considerará a possibilidade de dar execução à pena que foi aplicada em conformidade com o direito do Estado Parte requerente ou ao que dessa pena faltar cumprir.

13. Qualquer pessoa que seja objeto de um processo devido a qualquer das infrações às quais se aplica o presente Artigo terá garantido um tratamento eqüitativo em todas as fases do processo, incluindo o gozo de todos os direitos e garantias previstos no direito interno do Estado Parte em cujo território se encontra.

14. Nenhuma disposição da presente Convenção deverá ser interpretada no sentido de que impõe uma obrigação de extraditar a um Estado Parte requerido, se existirem sérias razões para supor que o pedido foi apresentado com a finalidade de perseguir ou punir uma pessoa em razão do seu sexo, raça, religião, nacionalidade, origem étnica ou opiniões políticas, ou que a satisfação daquele pedido provocaria um prejuízo a essa pessoa por alguma destas razões.

15. Os Estados Partes não poderão recusar um pedido de extradição unicamente por considerarem que a infração envolve também questões fiscais.

16. Antes de recusar a extradição, o Estado Parte requerido consultará, se for caso disso, o Estado Parte requerente, a fim de lhe dar a mais ampla possibilidade de apresentar as suas razões e de fornecer informações em apoio das suas alegações. 
17. Os Estados Partes procurarão celebrar acordos ou protocolos bilaterais e multilaterais com o objetivo de permitir a extradição ou de aumentar a sua eficácia.

\section{Artigo 17}

\section{Transferência de pessoas condenadas}

Os Estados Partes poderão considerar a celebração de acordos ou protocolos bilaterais ou multilaterais relativos à transferência para o seu território de pessoas condenadas a penas de prisão ou outras penas de privação de liberdade devido a infrações previstas na presente Convenção, para que aí possam cumprir o resto da pena.

\section{Artigo 18}

\section{Assistência judiciária recíproca}

1. Os Estados Partes prestarão reciprocamente toda a assistência judiciária possível nas investigações, nos processos e em outros atos judiciais relativos às infrações previstas pela presente Convenção, nos termos do Artigo 3, e prestarão reciprocamente uma assistência similar quando o Estado Parte requerente tiver motivos razoáveis para suspeitar de que a infração a que se referem as alíneas a) ou b) do parágrafo 1 do Artigo 3 é de caráter transnacional, inclusive quando as vítimas, as testemunhas, o produto, os instrumentos ou os elementos de prova destas infrações se encontrem no Estado Parte requerido e nelas esteja implicado um grupo criminoso organizado.

2. Será prestada toda a cooperação judiciária possível, tanto quanto o permitam as leis, tratados, acordos e protocolos pertinentes do Estado Parte requerido, no âmbito de investigações, processos e outros atos judiciais relativos a infrações pelas quais possa ser considerada responsável uma pessoa coletiva no Estado Parte requerente, em conformidade com o Artigo 10 da presente Convenção. 
3. A cooperação judiciária prestada em aplicação do presente Artigo pode ser solicitada para os seguintes efeitos:

a) Recolher testemunhos ou depoimentos;

b) Notificar atos judiciais;

c) Efetuar buscas, apreensões e embargos;

d) Examinar objetos e locais;

e) Fornecer informações, elementos de prova e pareceres de peritos;

f) Fornecer originais ou cópias certificadas de documentos e processos pertinentes, incluindo documentos administrativos, bancários, financeiros ou comerciais e documentos de empresas;

g) Identificar ou localizar os produtos do crime, bens, instrumentos ou outros elementos para fins probatórios;

h) Facilitar o comparecimento voluntário de pessoas no Estado Parte requerente;

i) Prestar qualquer outro tipo de assistência compatível com o direito interno do Estado Parte requerido.

4. Sem prejuízo do seu direito interno, as autoridades competentes de um Estado Parte poderão, sem pedido prévio, comunicar informações relativas a questões penais a uma autoridade competente de outro Estado Parte, se considerarem que estas informações poderão ajudar a empreender ou concluir com êxito investigações e processos penais ou conduzir este último Estado Parte a formular um pedido ao abrigo da presente Convenção.

5. A comunicação de informações em conformidade com o parágrafo 4 do presente Artigo será efetuada sem prejuízo das investigações e dos processos penais no Estado cujas autoridade competentes fornecem as informações. As autoridades competentes que recebam estas informações deverão satisfazer qualquer pedido no sentido de manter confidenciais as referidas informações, mesmo se apenas temporariamente, ou de restringir a 
sua utilização. Todavia, tal não impedirá o Estado Parte que receba as informações de revelar, no decurso do processo judicial, informações que inocentem um argüido. Neste último caso, o Estado Parte que recebeu as informações avisará o Estado Parte que as comunicou antes de as revelar e, se lhe for pedido, consultará este último. Se, num caso excepcional, não for possível uma comunicação prévia, o Estado Parte que recebeu as informações dará conhecimento da revelação, prontamente, ao Estado Parte que as tenha comunicado.

6. As disposições do presente Artigo em nada prejudicam as obrigações decorrentes de qualquer outro tratado bilateral ou multilateral que regule, ou deva regular, inteiramente ou em parte, a cooperação judiciária.

7. Os parágrafos 9 a 29 do presente Artigo serão aplicáveis aos pedidos feitos em conformidade com o presente Artigo, no caso de os Estados Partes em questão não estarem ligados por um tratado de cooperação judiciária. Se os referidos Estados Partes estiverem ligados por tal tratado, serão aplicáveis as disposições correspondentes desse tratado, a menos que os Estados Partes concordem em aplicar, em seu lugar, as disposições dos parágrafos 9 a 29 do presente Artigo. Os Estados Partes são fortemente instados a aplicar estes números, se tal facilitar a cooperação.

8. Os Estados Partes não poderão invocar o sigilo bancário para recusar a cooperação judiciária prevista no presente Artigo.

9. Os Estados Partes poderão invocar a ausência de dupla criminalização para recusar prestar a assistência judiciária prevista no presente Artigo. $\mathrm{O}$ Estado Parte requerido poderá, não obstante, quando o considerar apropriado, prestar esta assistência, na medida em que o decida por si próprio, independentemente de o ato estar ou não tipificado como uma infração no direito interno do Estado Parte requerido.

10. Qualquer pessoa detida ou a cumprir pena no território de um Estado Parte, cuja presença seja requerida num outro Estado Parte para efeitos de identificação, para testemunhar ou para contribuir por qualquer outra forma 
para a obtenção de provas no âmbito de investigações, processos ou outros atos judiciais relativos às infrações visadas na presente Convenção, pode ser objeto de uma transferência, se estiverem reunidas as seguintes condições:

a) Se referida pessoa, devidamente informada, der o seu livre consentimento;

b) Se as autoridades competentes dos dois Estados Partes em questão derem o seu consentimento, sob reserva das condições que estes Estados Partes possam considerar convenientes.

11. Para efeitos do parágrafo 10 do presente Artigo:

a) O Estado Parte para o qual a transferência da pessoa em questão for efetuada terá o poder e a obrigação de a manter detida, salvo pedido ou autorização em contrário do Estado Parte do qual a pessoa foi transferida;

b) O Estado Parte para o qual a transferência for efetuada cumprirá prontamente a obrigação de entregar a pessoa à guarda do Estado Parte do qual foi transferida, em conformidade com o que tenha sido previamente acordado ou com o que as autoridades competentes dos dois Estados Partes tenham decidido;

c) O Estado Parte para o qual for efetuada a transferência não poderá exigir do Estado Parte do qual a transferência foi efetuada que abra um processo de extradição para que a pessoa lhe seja entregue;

d) O período que a pessoa em questão passe detida no Estado Parte para o qual for transferida é contado para o cumprimento da pena que lhe tenha sido aplicada no Estado Parte do qual for transferida;

12. A menos que o Estado Parte do qual a pessoa for transferida, ao abrigo dos parágrafos 10 e 11 do presente Artigo, esteja de acordo, a pessoa em questão, seja qual for a sua nacionalidade, não será objecto de processo judicial, detida, punida ou sujeita a outras restrições à sua liberdade de movimentos no território do Estado Parte para o qual seja transferida, 
devido a atos, omissões ou condenações anteriores à sua partida do território do Estado Parte do qual foi transferida.

13. Cada Estado Parte designará uma autoridade central que terá a responsabilidade e o poder de receber pedidos de cooperação judiciária e, quer de os executar, quer de os transmitir às autoridades competentes para execução. Se um Estado Parte possuir uma região ou um território especial dotado de um sistema de cooperação judiciária diferente, poderá designar uma autoridade central distinta, que terá a mesma função para a referida região ou território. As autoridades centrais deverão assegurar a execução ou a transmissão rápida e em boa e devida forma dos pedidos recebidos. Quando a autoridade central transmitir o pedido a uma autoridade competente para execução, instará pela execução rápida e em boa e devida forma do pedido por parte da autoridade competente. O Secretário Geral da Organização das Nações Unidas será notificado da autoridade central designada para este efeito no momento em que cada Estado Parte depositar os seus instrumentos de ratificação, aceitação, aprovação ou adesão à presente Convenção. Os pedidos de cooperação judiciária e qualquer comunicação com eles relacionada serão transmitidos às autoridades centrais designadas pelos Estados Partes. A presente disposição não afetará o direito de qualquer Estado Parte a exigir que estes pedidos e comunicações the sejam remetidos por via diplomática e, em caso de urgência, e se os Estados Partes nisso acordarem, por intermédio da Organização Internacional de Polícia Criminal, se tal for possível.

14. Os pedidos serão formulados por escrito ou, se possível, por qualquer outro meio capaz de produzir registro escrito, numa língua que seja aceita pelo Estado Parte requerido, em condições que permitam a este Estado Parte verificar a sua autenticidade. O Secretário Geral das Nações Unidas será notificado a respeito da língua ou línguas aceitas por cada Estado Parte no momento em que o Estado Parte em questão depositar os seus instrumentos de ratificação, aceitação, aprovação ou adesão à presente Convenção. Em caso de urgência, e se os Estados Partes nisso acordarem, 
os pedidos poderão ser feitos oralmente, mais deverão ser imediatamente confirmados por escrito.

15. Um pedido de assistência judiciária deverá conter as seguintes informações:

a) A designação da autoridade que emite o pedido;

b) $\mathrm{O}$ objeto e a natureza da investigação, dos processos ou dos outros atos judiciais a que se refere o pedido, bem como o nome e as funções da autoridade que os tenha a cargo;

c) Um resumo dos fatos relevantes, salvo no caso dos pedidos efetuados para efeitos de notificação de atos judiciais;

d) Uma descrição da assistência pretendida e pormenores de qualquer procedimento específico que o Estado Parte requerente deseje ver aplicado;

e) Caso seja possível, a identidade, endereço e nacionalidade de qualquer pessoa visada; e

f) O fim para o qual são pedidos os elementos, informações ou medidas.

16. O Estado Parte requerido poderá solicitar informações adicionais, quando tal se afigure necessário à execução do pedido em conformidade com o seu direito interno, ou quando tal possa facilitar a execução do pedido.

17. Qualquer pedido será executado em conformidade com o direito interno do Estado Parte requerido e, na medida em que tal não contrarie este direito e seja possível, em conformidade com os procedimentos especificados no pedido.

18. Se for possível e em conformidade com os princípios fundamentais do direito interno, quando uma pessoa que se encontre no território de um Estado Parte deva ser ouvida como testemunha ou como perito pelas autoridades judiciais de outro Estado Parte, o primeiro Estado Parte poderá, a pedido do outro, autorizar a sua audição por videoconferência, se não for 
possível ou desejável que a pessoa compareça no território do Estado Parte requerente. Os Estados Partes poderão acordar em que a audição seja conduzida por uma autoridade judicial do Estado Parte requerente e que a ela assista uma autoridade judicial do Estado Parte requerido.

19. O Estado Parte requerente não comunicará nem utilizará as informações ou os elementos de prova fornecidos pelo Estado Parte requerido para efeitos de investigações, processos ou outros atos judiciais diferentes dos mencionados no pedido sem o consentimento prévio do Estado Parte requerido. $\mathrm{O}$ disposto neste número não impedirá o Estado Parte requerente de revelar, durante o processo, informações ou elementos de prova ilibatórios de um argüido. Neste último caso, o Estado Parte requerente avisará, antes da revelação, o Estado Parte requerido e, se tal lhe for pedido, consultará neste último. Se, num caso excepcional, não for possível uma comunicação prévia, o Estado Parte requerente informará da revelação, prontamente, o Estado Parte requerido.

20. O Estado Parte requerente poderá exigir que o Estado Parte requerido guarde sigilo sobre o pedido e o seu conteúdo, salvo na medida do que seja necessário para o executar. Se o Estado Parte requerido não puder satisfazer esta exigência, informará prontamente o Estado Parte requerente.

21. A cooperação judiciária poderá ser recusada:

a) Se o pedido não for feito em conformidade com o disposto no presente Artigo;

b) Se o Estado Parte requerido considerar que a execução do pedido pode afetar sua soberania, sua segurança, sua ordem pública ou outros interesses essenciais;

c) Se o direito interno do Estado Parte requerido proibir suas autoridades de executar as providências solicitadas com relação a uma infração análoga que tenha sido objeto de investigação ou de procedimento judicial no âmbito da sua própria competência; 
d) Se a aceitação do pedido contrariar o sistema jurídico do Estado Parte requerido no que se refere à cooperação judiciária.

22. Os Estados Partes não poderão recusar um pedido de cooperação judiciária unicamente por considerarem que a infração envolve também questões fiscais.

23. Qualquer recusa de cooperação judiciária deverá ser fundamentada.

24. O Estado Parte requerido executará o pedido de cooperação judiciária tão prontamente quanto possível e terá em conta, na medida do possível, todos os prazos sugeridos pelo Estado Parte requerente para os quais sejam dadas justificações, de preferência no pedido. O Estado Parte requerido responderá aos pedidos razoáveis do Estado Parte requerente quanto ao andamento das diligências solicitadas. Quando a assistência pedida deixar de ser necessária, o Estado Parte requerente informará prontamente desse fato o Estado Parte requerido.

25. A cooperação judiciária poderá ser diferida pelo Estado Parte requerido por interferir com uma investigação, processos ou outros atos judiciais em curso.

26. Antes de recusar um pedido feito ao abrigo do parágrafo 21 do presente Artigo ou de diferir a sua execução ao abrigo do parágrafo 25, o Estado Parte requerido estudará com o Estado Parte requerente a possibilidade de prestar a assistência sob reserva das condições que considere necessárias. Se o Estado Parte requerente aceitar a assistência sob reserva destas condições, deverá respeitá-las.

27. Sem prejuízo da aplicação do parágrafo 12 do presente Artigo, uma testemunha, um perito ou outra pessoa que, a pedido do Estado Parte requerente, aceite depor num processo ou colaborar numa investigação, em processos ou outros atos judiciais no território do Estado Parte requerente, não será objeto de processo, detida, punida ou sujeita a outras restrições à sua liberdade pessoal neste território, devido a atos, omissões ou 
condenações anteriores à sua partida do território do Estado Parte requerido. Esta imunidade cessa quando a testemunha, o perito ou a referida pessoa, tendo tido, durante um período de quinze dias consecutivos ou qualquer outro período acordado pelos Estados Partes, a contar da data em que recebeu a comunicação oficial de que a sua presença já não era exigida pelas autoridades judiciais, a possibilidade de deixar o território do Estado Parte requerente, nele tenha voluntariamente permanecido ou, tendo-o deixado, a ele tenha regressado de livre vontade.

28. As despesas correntes com a execução de um pedido serão suportadas pelo Estado Parte requerido, salvo acordo noutro sentido dos Estados Partes interessados. Quando venham a revelar-se necessárias despesas significativas ou extraordinárias para executar o pedido, os Estados Partes consultar-se-ão para fixar as condições segundo as quais o pedido deverá ser executado, bem como o modo como as despesas serão assumidas.

29. O Estado Parte requerido:

a) Fornecerá ao Estado Parte requerente cópias dos processos, documentos ou informações administrativas que estejam em seu poder e que, por força do seu direito interno, estejam acessíveis ao público;

b) Poderá, se assim o entender, fornecer ao Estado Parte requerente, na íntegra ou nas condições que considere apropriadas, cópias de todos os processos, documentos ou informações que estejam na sua posse e que, por força do seu direito interno, não sejam acessíveis ao público.

30. Os Estados Partes considerarão, se necessário, a possibilidade de celebrarem acordos ou protocolos bilaterais ou multilaterais que sirvam os objetivos e as disposições do presente Artigo, reforçando-as ou dando-lhes maior eficácia. 


\section{Artigo 19}

\section{Investigações conjuntas}

Os Estados Partes considerarão a possibilidade de celebrar acordos ou protocolos bilaterais ou multilaterais em virtude dos quais, com respeito a matérias que sejam objeto de investigação, processos ou ações judiciais em um ou mais Estados, as autoridades competentes possam estabelecer órgãos mistos de investigação. Na ausência de tais acordos ou protocolos, poderá ser decidida casuisticamente a realização de investigações conjuntas. Os Estados Partes envolvidos agirão de modo a que a soberania do Estado Parte em cujo território decorra a investigação seja plenamente respeitada.

\section{Artigo 20}

\section{Técnicas especiais de investigação}

1. Se os princípios fundamentais do seu ordenamento jurídico nacional o permitirem, cada Estado Parte, tendo em conta as suas possibilidades e em conformidade com as condições prescritas no seu direito interno, adotará as medidas necessárias para permitir o recurso apropriado a entregas vigiadas e, quando o considere adequado, o recurso a outras técnicas especiais de investigação, como a vigilância eletrônica ou outras formas de vigilância e as operações de infiltração, por parte das autoridades competentes no seu território, a fim de combater eficazmente a criminalidade organizada.

2. Para efeitos de investigações sobre as infrações previstas na presente Convenção, os Estados Partes são instados a celebrar, se necessário, acordos ou protocolos bilaterais ou multilaterais apropriados para recorrer às técnicas especiais de investigação, no âmbito da cooperação internacional. Estes acordos ou protocolos serão celebrados e aplicados sem prejuízo do princípio da igualdade soberana dos Estados e serão executados em estrita conformidade com as disposições neles contidas.

3. Na ausência dos acordos ou protocolos referidos no parágrafo 2 do presente Artigo, as decisões de recorrer a técnicas especiais de investigação 
a nível internacional serão tomadas casuisticamente e poderão, se necessário, ter em conta acordos ou protocolos financeiros relativos ao exercício de jurisdição pelos Estados Partes interessados.

4. As entregas vigiadas a que se tenha decidido recorrer a nível internacional poderão incluir, com o consentimento dos Estados Partes envolvidos, métodos como a intercepção de mercadorias e a autorização de prosseguir o seu encaminhamento, sem alteração ou após subtração ou substituição da totalidade ou de parte dessas mercadorias.

\section{Artigo 21}

\section{Transferência de processos penais}

Os Estados Partes considerarão a possibilidade de transferirem mutuamente os processos relativos a uma infração prevista na presente Convenção, nos casos em que esta transferência seja considerada necessária no interesse da boa administração da justiça e, em especial, quando estejam envolvidas várias jurisdições, a fim de centralizar a instrução dos processos.

\section{Artigo 22}

\section{Estabelecimento de antecedentes penais}

Cada Estado Parte poderá adotar as medidas legislativas ou outras que sejam necessárias para ter em consideração, nas condições e para os efeitos que entender apropriados, qualquer condenação de que o presumível autor de uma infração tenha sido objeto noutro Estado, a fim de utilizar esta informação no âmbito de um processo penal relativo a uma infração prevista na presente Convenção.

\section{Artigo 23}

\section{Criminalização da obstrução à justiça}

Cada Estado Parte adotará medidas legislativas e outras consideradas necessárias para conferir o caráter de infração penal aos seguintes atos, quando cometidos intencionalmente: 
a) O recurso à força física, a ameaças ou a intimidação, ou a promessa, oferta ou concessão de um benefício indevido para obtenção de um falso testemunho ou para impedir um testemunho ou a apresentação de elementos de prova num processo relacionado com a prática de infrações previstas na presente Convenção;

b) $\mathrm{O}$ recurso à força física, a ameaças ou a intimidação para impedir um agente judicial ou policial de exercer os deveres inerentes à sua função relativamente à prática de infrações previstas na presente Convenção. O disposto na presente alínea não prejudica o direito dos Estados Partes de disporem de legislação destinada a proteger outras categorias de agentes públicos.

\section{Artigo 24}

\section{Proteção das testemunhas}

1. Cada Estado Parte, dentro das suas possibilidades, adotará medidas apropriadas para assegurar uma proteção eficaz contra eventuais atos de represália ou de intimidação das testemunhas que, no âmbito de processos penais, deponham sobre infrações previstas na presente Convenção e, quando necessário, aos seus familiares ou outras pessoas que lhes sejam próximas.

2. Sem prejuízo dos direitos do argüido, incluindo o direito a um julgamento regular, as medidas referidas no parágrafo 1 do presente Artigo poderão incluir, entre outras:

a) Desenvolver, para a proteção física destas pessoas, procedimentos que visem, consoante as necessidades e na medida do possível, nomeadamente, fornecer-lhes um novo domicílio e impedir ou restringir a divulgação de informações relativas à sua identidade e paradeiro;

b) Estabelecer normas em matéria de prova que permitam às testemunhas depor de forma a garantir a sua segurança, nomeadamente autorizando-as a 
depor com recurso a meios técnicos de comunicação, como ligações de vídeo ou outros meios adequados.

3. Os Estados Partes considerarão a possibilidade de celebrar acordos com outros Estados para facultar um novo domicílio às pessoas referidas no parágrafo 1 do presente Artigo.

4. As disposições do presente Artigo aplicam-se igualmente às vítimas, quando forem testemunhas.

\section{Artigo 25}

\section{Assistência e proteção às vítimas}

1. Cada Estado Parte adotará, segundo as suas possibilidades, medidas apropriadas para prestar assistência e assegurar a proteção às vítimas de infrações previstas na presente Convenção, especialmente em caso de ameaça de represálias ou de intimidação.

2. Cada Estado Parte estabelecerá procedimentos adequados para que as vítimas de infrações previstas na presente Convenção possam obter reparação.

3. Cada Estado Parte, sem prejuízo do seu direito interno, assegurará que as opiniões e preocupações das vítimas sejam apresentadas e tomadas em consideração nas fases adequadas do processo penal aberto contra os autores de infrações, por forma que não prejudique os direitos da defesa.

Artigo 26

\section{Medidas para intensificar a cooperação com as autoridades competentes para a aplicação da lei}

1. Cada Estado Parte tomará as medidas adequadas para encorajar as pessoas que participem ou tenham participado em grupos criminosos organizados:

a) A fornecerem informações úteis às autoridades competentes para efeitos de investigação e produção de provas, nomeadamente 
i) A identidade, natureza, composição, estrutura, localização ou atividades dos grupos criminosos organizados;

ii) As conexões, inclusive conexões internacionais, com outros grupos criminosos organizados;

iii) As infrações que os grupos criminosos organizados praticaram ou poderão vir a praticar;

b) A prestarem ajuda efetiva e concreta às autoridades competentes, susceptível de contribuir para privar os grupos criminosos organizados dos seus recursos ou do produto do crime.

2. Cada Estado Parte poderá considerar a possibilidade, nos casos pertinentes, de reduzir a pena de que é passível um argüido que coopere de forma substancial na investigação ou no julgamento dos autores de uma infração prevista na presente Convenção.

3. Cada Estado Parte poderá considerar a possibilidade, em conformidade com os princípios fundamentais do seu ordenamento jurídico interno, de conceder imunidade a uma pessoa que coopere de forma substancial na investigação ou no julgamento dos autores de uma infração prevista na presente Convenção.

4. A proteção destas pessoas será assegurada nos termos do Artigo 24 da presente Convenção.

5. Quando uma das pessoas referidas no parágrafo 1 do presente Artigo se encontre num Estado Parte e possa prestar uma cooperação substancial às autoridades competentes de outro Estado Parte, os Estados Partes em questão poderão considerar a celebração de acordos, em conformidade com o seu direito interno, relativos à eventual concessão, pelo outro Estado Parte, do tratamento descrito nos parágrafos 2 e 3 do presente Artigo. 


\section{Artigo 27}

\section{Cooperação entre as autoridades competentes para a aplicação da lei}

1. Os Estados Partes cooperarão estreitamente, em conformidade com os seus respectivos ordenamentos jurídicos e administrativos, a fim de reforçar a eficácia das medidas de controle do cumprimento da lei destinadas a combater as infrações previstas na presente Convenção. Especificamente, cada Estado Parte adotará medidas eficazes para:

a) Reforçar ou, se necessário, criar canais de comunicação entre as suas autoridades, organismos e serviços competentes, para facilitar a rápida e segura troca de informações relativas a todos os aspectos das infrações previstas na presente Convenção, incluindo, se os Estados Partes envolvidos o considerarem apropriado, ligações com outras atividades criminosas;

b) Cooperar com outros Estados Partes, quando se trate de infrações previstas na presente Convenção, na condução de investigações relativas aos seguintes aspectos:

i) Identidade, localização e atividades de pessoas suspeitas de implicação nas referidas infrações, bem como localização de outras pessoas envolvidas;

ii) Movimentação do produto do crime ou dos bens provenientes da prática destas infrações;

iii) Movimentação de bens, equipamentos ou outros instrumentos utilizados ou destinados a ser utilizados na prática destas infrações;

c) Fornecer, quando for caso disso, os elementos ou as quantidades de substâncias necessárias para fins de análise ou de investigação;

d) Facilitar uma coordenação eficaz entre as autoridades, organismos e serviços competentes e promover o intercâmbio de pessoal e de peritos, incluindo, sob reserva da existência de acordos ou protocolos bilaterais entre os Estados Partes envolvidos, a designação de agentes de ligação; 
e) Trocar informações com outros Estados Partes sobre os meios e métodos específicos utilizados pelos grupos criminosos organizados, incluindo, se for caso disso, sobre os itinerários e os meios de transporte, bem como o uso de identidades falsas, de documentos alterados ou falsificados ou outros meios de dissimulação das suas atividades;

f) Trocar informações e coordenar as medidas administrativas e outras tendo em vista detectar o mais rapidamente possível as infrações previstas na presente Convenção.

2. Para dar aplicação à presente Convenção, os Estados Partes considerarão a possibilidade de celebrar acordos ou protocolos bilaterais ou multilaterais que prevejam uma cooperação direta entre as suas autoridades competentes para a aplicação da lei e, quando tais acordos ou protocolos já existam, considerarão a possibilidade de os alterar. Na ausência de tais acordos entre os Estados Partes envolvidos, estes últimos poderão basear-se na presente Convenção para instituir uma cooperação em matéria de detecção e repressão das infrações previstas na presente Convenção. Sempre que tal se justifique, os Estados Partes utilizarão plenamente os acordos ou protocolos, incluindo as organizações internacionais ou regionais, para intensificar a cooperação entre as suas autoridades competentes para a aplicação da lei.

3. Os Estados Partes procurarão cooperar, na medida das suas possibilidades, para enfrentar o crime organizado transnacional praticado com recurso a meios tecnológicos modernos.

\section{Artigo 28}

\section{Coleta, intercâmbio e análise de informações sobre a natureza do crime organizado}

1. Cada Estado Parte considerará a possibilidade de analisar, em consulta com os meios científicos e universitários, as tendências da criminalidade 
organizada no seu território, as circunstâncias em que opera e os grupos profissionais e tecnologias envolvidos.

2. Os Estados Partes considerarão a possibilidade de desenvolver as suas capacidades de análise das atividades criminosas organizadas e de as partilhar diretamente entre si e por intermédio de organizações internacionais e regionais. Para este efeito, deverão ser elaboradas e aplicadas, quando for caso disso, definições, normas e metodologias comuns.

3. Cada Estado Parte considerará o estabelecimento de meios de acompanhamento das suas políticas e das medidas tomadas para combater o crime organizado, avaliando a sua aplicação e eficácia.

\section{Artigo 29}

\section{Formação e assistência técnica}

1. Cada Estado Parte estabelecerá, desenvolverá ou melhorará, na medida das necessidades, programas de formação específicos destinados ao pessoal das autoridades competentes para a aplicação da lei, incluindo promotores públicos, juizes de instrução e funcionários aduaneiros, bem como outro pessoal que tenha por função prevenir, detectar e reprimir as infrações previstas na presente Convenção. Estes programas, que poderão prever cessões e intercâmbio de pessoal, incidirão especificamente, na medida em que o direito interno o permita, nos seguintes aspectos:

a) Métodos utilizados para prevenir, detectar e combater as infrações previstas na presente Convenção;

b) Rotas e técnicas utilizadas pelas pessoas suspeitas de implicação em infrações previstas na presente Convenção, incluindo nos Estados de trânsito, e medidas adequadas de combate;

c) Vigilância das movimentações dos produtos de contrabando;

d) Detecção e vigilância das movimentações do produto do crime, de bens, equipamentos ou outros instrumentos, de métodos de transferência, 
dissimulação ou disfarce destes produtos, bens, equipamentos ou outros instrumentos, bem como métodos de luta contra a lavagem de dinheiro e outras infrações financeiras;

e) Coleta de provas;

f) Técnicas de controle nas zonas francas e nos portos francos;

g) Equipamentos e técnicas modernas de detecção e de repressão, incluindo a vigilância eletrônica, as entregas vigiadas e as operações de infiltração;

h) Métodos utilizados para combater o crime organizado transnacional cometido por meio de computadores, de redes de telecomunicações ou outras tecnologias modernas; e

i) Métodos utilizados para a proteção das vítimas e das testemunhas.

2. Os Estados Partes deverão cooperar entre si no planejamento e execução de programas de investigação e de formação concebidos para o intercâmbio de conhecimentos especializados nos domínios referidos no parágrafo 1 do presente Artigo e, para este efeito, recorrerão também, quando for caso disso, a conferências e seminários regionais e internacionais para promover a cooperação e estimular as trocas de pontos de vista sobre problemas comuns, incluindo os problemas e necessidades específicos dos Estados de trânsito.

3. Os Estados Partes incentivarão as atividades de formação e de assistência técnica suscetíveis de facilitar a extradição e a cooperação judiciária. Estas atividades de cooperação e de assistência técnica poderão incluir ensino de idiomas, cessões e intercâmbio do pessoal das autoridades centrais ou de organismos que tenham responsabilidades nos domínios em questão.

4. Sempre que se encontrem em vigor acordos bilaterais ou multilaterais, os Estados Partes reforçarão, tanto quanto for necessário, as medidas tomadas no sentido de otimizar as atividades operacionais e de formação no âmbito de organizações internacionais e regionais e no âmbito de outros acordos ou protocolos bilaterais e multilaterais na matéria. 


\section{Artigo 30}

\section{Outras medidas: aplicação da Convenção através do desenvolvimento econômico e da assistência técnica}

1. Os Estados Partes tomarão as medidas adequadas para assegurar a melhor aplicação possível da presente Convenção através da cooperação internacional, tendo em conta os efeitos negativos da criminalidade organizada na sociedade em geral e no desenvolvimento sustentável em particular.

2. Os Estados Partes farão esforços concretos, na medida do possível, em coordenação entre si e com as organizações regionais e internacionais:

a) Para desenvolver a sua cooperação a vários níveis com os países em desenvolvimento, a fim de reforçar a capacidade destes para prevenir e combater a criminalidade organizada transnacional;

b) Para aumentar a assistência financeira e material aos países em desenvolvimento, a fim de apoiar os seus esforços para combater eficazmente a criminalidade organizada transnacional e ajudá-los a aplicar com êxito a presente Convenção;

c) Para fornecer uma assistência técnica aos países em desenvolvimento e aos países com uma economia de transição, a fim de ajudá-los a obter meios para a aplicação da presente Convenção. Para este efeito, os Estados Partes procurarão destinar voluntariamente contribuições adequadas e regulares a uma conta constituída especificamente para este fim no âmbito de um mecanismo de financiamento das Nações Unidas. Os Estados Partes poderão também considerar, especificamente, em conformidade com o seu direito interno e as disposições da presente Convenção, a possibilidade de destinarem à conta acima referida uma percentagem dos fundos ou do valor correspondente do produto do crime ou dos bens confiscados em aplicação das disposições da presente Convenção; 
d) Para incentivar e persuadir outros Estados e instituições financeiras, quando tal se justifique, a associarem-se aos esforços desenvolvidos em conformidade com o presente Artigo, nomeadamente fornecendo aos países em desenvolvimento mais programas de formação e material moderno, a fim de os ajudar a alcançar os objetivos da presente Convenção.

e) Tanto quanto possível, estas medidas serão tomadas sem prejuízo dos compromissos existentes em matéria de assistência externa ou de outros acordos de cooperação financeira a nível bilateral, regional ou internacional.

4. Os Estados Partes poderão celebrar acordos ou protocolos bilaterais ou multilaterais relativos a assistência técnica e logística, tendo em conta os acordos financeiros necessários para assegurar a eficácia dos meios de cooperação internacional previstos na presente Convenção, e para prevenir, detectar e combater a criminalidade organizada transnacional.

\section{Artigo 31}

\section{Prevenção}

1. Os Estados Partes procurarão elaborar e avaliar projetos nacionais, bem como estabelecer e promover as melhores práticas e políticas para prevenir a criminalidade organizada transnacional.

2. Em conformidade com os princípios fundamentais do seu direito interno, os Estados Partes procurarão reduzir, através de medidas legislativas, administrativas ou outras que sejam adequadas, as possibilidades atuais ou futuras de participação de grupos criminosos organizados em negócios lícitos utilizando o produto do crime. Estas medidas deverão incidir:

a) No fortalecimento da cooperação entre autoridades competentes para a aplicação da lei ou promotores e entidades privadas envolvidas, incluindo empresas;

b) Na promoção da elaboração de normas e procedimentos destinados a preservar a integridade das entidades públicas e privadas envolvidas, bem 
como de códigos de conduta para determinados profissionais, em particular advogados, tabeliães, consultores tributários e contadores;

c) Na prevenção da utilização indevida, por grupos criminosos organizados, de concursos públicos, bem como de subvenções e licenças concedidas por autoridades públicas para a realização de atividades comerciais;

d) Na prevenção da utilização indevida de pessoas jurídicas por grupos criminosos organizados; estas medidas poderão incluir:

i) O estabelecimento de registros públicos de pessoas jurídicas e físicas envolvidas na criação, gestão e financiamento de pessoas jurídicas;

ii) A possibilidade de privar, por decisão judicial ou por qualquer outro meio adequado, as pessoas condenadas por infrações previstas na presente Convenção, por um período adequado, do direito de exercerem funções de direção de pessoas jurídicas estabelecidas no seu território;

iii) $\mathrm{O}$ estabelecimento de registos nacionais de pessoas que tenham sido privadas do direito de exercerem funções de direção de pessoas jurídicas; e

iv) $\mathrm{O}$ intercâmbio de informações contidas nos registros referidos nas incisos i) e iii) da presente alínea com as autoridades competentes dos outros Estados Partes.

3. Os Estados Partes procurarão promover a reinserção na sociedade das pessoas condenadas por infrações previstas na presente Convenção.

4. Os Estados Partes procurarão avaliar periodicamente os instrumentos jurídicos e as práticas administrativas aplicáveis, a fim de determinar se contêm lacunas que permitam aos grupos criminosos organizados fazerem deles utilização indevida.

5. Os Estados Partes procurarão sensibilizar melhor o público para a existência, as causas e a gravidade da criminalidade organizada transnacional e para a ameaça que representa. Poderão fazê-lo, quando for o caso, por intermédio dos meios de comunicação social e adotando medidas 
destinadas a promover a participação do público nas ações de prevenção e combate à criminalidade.

6. Cada Estado Parte comunicará ao Secretário Geral da Organização das Nações Unidas o nome e o endereço da(s) autoridade(s) que poderão assistir os outros Estados Partes na aplicação das medidas de prevenção do crime organizado transnacional.

7. Quando tal se justifique, os Estados Partes colaborarão, entre si e com as organizações regionais e internacionais competentes, a fim de promover e aplicar as medidas referidas no presente Artigo. A este título, participarão em projetos internacionais que visem prevenir a criminalidade organizada transnacional, atuando, por exemplo, sobre os fatores que tornam os grupos socialmente marginalizados vulneráveis à sua ação.

\section{Artigo 32}

\section{Conferência das Partes na Convenção}

1. Será instituída uma Conferência das Partes na Convenção, para melhorar a capacidade dos Estados Partes no combate à criminalidade organizada transnacional e para promover e analisar a aplicação da presente Convenção.

2. O Secretário Geral da Organização das Nações Unidas convocará a Conferência das Partes, o mais tardar, um ano após a entrada em vigor da presente Convenção. A Conferência das Partes adotará um regulamento interno e regras relativas às atividades enunciadas nos parágrafos 3 e 4 do presente Artigo (incluindo regras relativas ao financiamento das despesas decorrentes dessas atividades).

3. A Conferência das Partes acordará em mecanismos destinados a atingir os objetivos referidos no parágrafo 1 do presente Artigo, nomeadamente:

a) Facilitando as ações desenvolvidas pelos Estados Partes em aplicação dos Artigos 29, 30 e 31 da presente Convenção, inclusive incentivando a mobilização de contribuições voluntárias; 
b) Facilitando o intercâmbio de informações entre Estados Partes sobre as características e tendências da criminalidade organizada transnacional e as práticas eficazes para a combater;

c) Cooperando com as organizações regionais e internacionais e as organizações não-governamentais competentes;

d) Avaliando, a intervalos regulares, a aplicação da presente Convenção;

e) Formulando recomendações a fim de melhorar a presente Convenção e a sua aplicação;

4. Para efeitos das alíneas d) e e) do parágrafo 3 do presente Artigo, a Conferência das Partes inteirar-se-á das medidas adotadas e das dificuldades encontradas pelos Estados Partes na aplicação da presente Convenção, utilizando as informações que estes lhe comuniquem e os mecanismos complementares de análise que venha a criar.

5. Cada Estado Parte comunicará à Conferência das Partes, a solicitação desta, informações sobre os seus programas, planos e práticas, bem como sobre as suas medidas legislativas e administrativas destinadas a aplicar a presente Convenção.

\section{Artigo 33}

\section{Secretariado}

1. O Secretário Geral da Organização das Nações Unidas fornecerá os serviços de secretariado necessários à Conferência das Partes na Convenção.

2. O secretariado:

a) Apoiará a Conferência das Partes na realização das atividades enunciadas no Artigo 32 da presente Convenção, tomará as disposições e prestará os serviços necessários para as sessões da Conferência das Partes; 
b) Assistirá os Estados Partes, a pedido destes, no fornecimento à Conferência das Partes das informações previstas no parágrafo 5 do Artigo 32 da presente Convenção; e

c) Assegurará a coordenação necessária com os secretariados das organizações regionais e internacionais.

\section{Artigo 34}

\section{Aplicação da Convenção}

1. Cada Estado Parte adotará as medidas necessárias, incluindo legislativas e administrativas, em conformidade com os princípios fundamentais do seu direito interno, para assegurar o cumprimento das suas obrigações decorrentes da presente Convenção.

2. As infrações enunciadas nos Artigos 5, 6, 8 e 23 da presente Convenção serão incorporadas no direito interno de cada Estado Parte, independentemente da sua natureza transnacional ou da implicação de um grupo criminoso organizado nos termos do parágrafo 1 do Artigo 3 da presente Convenção, salvo na medida em que o Artigo 5 da presente Convenção exija o envolvimento de um grupo criminoso organizado.

3. Cada Estado Parte poderá adotar medidas mais estritas ou mais severas do que as previstas na presente Convenção a fim de prevenir e combater a criminalidade organizada transnacional.

\section{Artigo 35}

\section{Solução de Controvérsias}

1. Os Estados Partes procurarão solucionar controvérsias relativas à interpretação ou aplicação da presente Convenção por negociação direta.

2. Qualquer controvérsia entre dois ou mais Estados Partes relativa à interpretação ou aplicação da presente Convenção que não possa ser resolvida por via negocial num prazo razoável será, a pedido de um destes Estados Partes, submetida a arbitragem. Se, no prazo de seis meses a contar 
da data do pedido de arbitragem, os Estados Partes não chegarem a acordo sobre a organização da arbitragem, qualquer deles poderá submeter a controvérsia ao Tribunal Internacional de Justiça, mediante requerimento em conformidade com o Estatuto do Tribunal.

3. Qualquer Estado Parte poderá, no momento da assinatura, da ratificação, da aceitação ou da aprovação da presente Convenção, ou da adesão a esta, declarar que não se considera vinculado pelo parágrafo 2 do presente Artigo. Os outros Estados Partes não estarão vinculados pelo parágrafo 2 do presente Artigo em relação a qualquer Estado Parte que tenha formulado esta reserva.

4. Um Estado Parte que tenha formulado uma reserva ao abrigo do parágrafo 3 do presente Artigo poderá retirá-la a qualquer momento, mediante notificação do Secretário Geral da Organização das Nações Unidas.

\section{Artigo 36}

\section{Assinatura, ratificação, aceitação, aprovação e adesão}

1. A presente Convenção será aberta à assinatura de todos os Estados entre 12 e 15 de Dezembro de 2000, em Palermo (Itália) e, seguidamente, na sede da Organização das Nações Unidas, em Nova Iorque, até 12 de Dezembro de 2002.

2. A presente Convenção estará igualmente aberta à assinatura de organizações regionais de integração econômica, desde que pelos menos um Estado-Membro dessa organização tenha assinado a presente Convenção, em conformidade com o parágrafo 1 do presente Artigo.

3. A presente Convenção será submetida a ratificação, aceitação ou aprovação. Os instrumentos de ratificação, aceitação ou aprovação serão depositados junto do Secretário Geral da Organização das Nações Unidas. Uma organização regional de integração econômica poderá depositar os seus instrumentos de ratificação, aceitação ou aprovação se pelo menos um 
dos seus Estados-Membros o tiver feito. Neste instrumento de ratificação, aceitação ou aprovação, a organização declarará o âmbito da sua competência em relação às questões que são objeto da presente Convenção. Informará igualmente o depositário de qualquer alteração relevante do âmbito da sua competência.

4. A presente Convenção estará aberta à adesão de qualquer Estado ou de qualquer organização regional de integração econômica de que, pelo menos, um Estado membro seja parte na presente Convenção. Os instrumentos de adesão serão depositados junto do Secretário Geral da Organização das Nações Unidas. No momento da sua adesão, uma organização regional de integração econômica declarará o âmbito da sua competência em relação às questões que são objeto da presente Convenção. Informará igualmente o depositário de qualquer alteração relevante do âmbito dessa competência.

\section{Artigo 37}

\section{Relação com os protocolos}

1. A presente Convenção poderá ser completada por um ou mais protocolos.

2. Para se tornar Parte num protocolo, um Estado ou uma organização regional de integração econômica deverá igualmente ser Parte na presente Convenção.

3. Um Estado Parte na presente Convenção não estará vinculado por um protocolo, a menos que se torne Parte do mesmo protocolo, em conformidade com as disposições deste.

4. Qualquer protocolo à presente Convenção será interpretado conjuntamente com a presente Convenção, tendo em conta a finalidade do mesmo protocolo. 


\section{Artigo 38}

\section{Entrada em vigor}

1. A presente Convenção entrará em vigor no nonagésimo dia seguinte à data de depósito do quadragésimo instrumento de ratificação, aceitação, aprovação ou adesão. Para efeitos do presente número, nenhum dos instrumentos depositados por uma organização regional de integração econômica será somado aos instrumentos já depositados pelos Estados membros dessa organização.

2. Para cada Estado ou organização regional de integração econômica que ratifique, aceite ou aprove a presente Convenção ou a ela adira após o depósito do quadragésimo instrumento pertinente, a presente Convenção entrará em vigor no trigésimo dia seguinte à data de depósito do instrumento pertinente do referido Estado ou organização.

\section{Artigo 39}

\section{Emendas}

1. Quando tiverem decorrido cinco anos a contar da entrada em vigor da presente Convenção, um Estado Parte poderá propor uma emenda e depositar o respectivo texto junto do Secretário Geral da Organização das Nações Unidas, que em seguida comunicará a proposta de emenda aos Estados Partes e à Conferência das Partes na Convenção, para exame da proposta e adoção de uma decisão. A Conferência das Partes esforçar-se-á por chegar a um consenso sobre qualquer emenda. Se todos os esforços nesse sentido se tiverem esgotado sem que se tenha chegado a acordo, será necessário, como último recurso para que a emenda seja aprovada, uma votação por maioria de dois terços dos votos expressos dos Estados Partes presentes na Conferência das Partes.

2. Para exercerem, ao abrigo do presente Artigo, o seu direito de voto nos domínios em que sejam competentes, as organizações regionais de integração econômica disporão de um número de votos igual ao número dos 
seus Estados-Membros que sejam Partes na presente Convenção. Não exercerão o seu direito de voto quando os seus Estados-Membros exercerem os seus, e inversamente.

3. Uma emenda aprovada em conformidade com o parágrafo 1 do presente Artigo estará sujeita à ratificação, aceitação ou aprovação dos Estados Partes.

4. Uma emenda aprovada em conformidade com o parágrafo 1 do presente Artigo entrará em vigor para um Estado Parte noventa dias após a data de depósito pelo mesmo Estado Parte junto do Secretário Geral da Organização das Nações Unidas de um instrumento de ratificação, aceitação ou aprovação da referida emenda.

5. Uma emenda que tenha entrado em vigor será vinculativa para os Estados Partes que tenham declarado o seu consentimento em serem por ela vinculados. Os outros Estados Partes permanecerão vinculados pelas disposições da presente Convenção e por todas as emendas anteriores que tenham ratificado, aceite ou aprovado.

\section{Artigo 40}

\section{Denúncia}

1. Um Estado Parte poderá denunciar a presente Convenção mediante notificação escrita dirigida ao Secretário Geral da Organização das Nações Unidas. A denúncia tornar-se-á efetiva um ano após a data da recepção da notificação pelo Secretário Geral.

2. Uma organização regional de integração econômica cessará de ser Parte na presente Convenção quando todos os seus Estados-Membros a tenham denunciado.

3. A denúncia da presente Convenção, em conformidade com o parágrafo 1 do presente Artigo, implica a denúncia de qualquer protocolo a ela associado. 


\section{Artigo 41}

\section{Depositário e línguas}

1. O Secretário Geral da Organização das Nações Unidas será o depositário da presente Convenção.

2. O original da presente Convenção, cujos textos em inglês, árabe, chinês, espanhol, francês e russo fazem igualmente fé, será depositado junto do Secretário Geral da Organização das Nações Unidas.

EM FÉ DO QUE os plenipotenciários abaixo assinados, devidamente mandatados para o efeito pelos respectivos Governos, assinaram a presente Convenção. 